UNIVERSIDADE DE SÃO PAULO

FACULDADE DE MEDICINA DE RIBEIRÃO PRETO

TIAGO ALEXANDRE COCIO

Identificação molecular e estudo sorológico de isolados clinicos e ambientais de Paracoccidioides spp. do Nordeste do Estado de São Paulo e Sudoeste do Estado de Minas Gerais 


\section{TIAGO ALEXANDRE COCIO}

\section{Identificação molecular e estudo sorológico de}

isolados clínicos e ambientais de Paracoccidioides

spp. do Nordeste do Estado de São Paulo e Sudoeste

do Estado de Minas Gerais

Tese apresentada à Faculdade de Medicina de Ribeirão Preto da Universidade de São Paulo para obtenção do Título de Doutor em Ciências Médicas.

Área de Concentração: Clínica Médica.

\section{Orientador: Prof. Dr. Roberto Martinez}

Versão corrigida da Tese de Doutorado apresentada ao Programa de PósGraduação em Clínica Médica no dia 17/11/2021. A versão original encontra-se disponível na Faculdade de Medicina de Ribeirão Preto/USP. 
Autorizo a reprodução e divulgação total ou parcial deste trabalho, por qualquer meio convencional ou eletrônico, para fins de estudo e pesquisa, desde que citada a fonte.

Catalogação da Publicação

Faculdade de Medicina de Ribeirão Preto Universidade de São Paulo

Creprodução autorizada pelo autor

Cocio, Tiago Alexandre.

Identificação molecular e estudo sorológico de isolados clínicos e ambientais de Paracoccidioides spp. do Nordeste do Estado de São Paulo e Sudoeste do Estado de Minas Gerais.

161p. 15 il. $30 \mathrm{~cm}$.

Tese (Doutorado) -- Faculdade de Medicina de Ribeirão Preto Universidade de São Paulo.

Programa de Clínica Médica

Orientador: Roberto Martínez

Descritores: 1. Paracoccidioides spp., 2. Paracoccidioidomicose, 3. Espécies filogenéticas, 4. Eco-Epidemiologia, 5. Exoantígenos miceliais, 6. Contraimunoeletroforese, 7. Imunodifusão dupla.

USP/FMRP 


\section{FOLHA DE APROVAÇÃO}

Aluno: Tiago Alexandre Cocio

Título: Identificação molecular e estudo sorológico de isolados clínicos e ambientais de Paracoccidioides spp. do Nordeste do Estado de São Paulo e Sudoeste do Estado de Minas Gerais.

Tese apresentada à Faculdade de Medicina de Ribeirão Preto da Universidade de São Paulo, para a obtenção do título de Doutor em Ciências Médicas.

Área de Concentração: Clínica Médica.

Aprovado em:

Banca Examinadora

Prof. Dr. Instituição:

Assinatura:

Prof. Dr. Instituição:

Assinatura:

Prof. Dr. Instituição:

Assinatura:

Prof. Dr. Instituição:

Assinatura: 


\section{Dedicatória}

Dedico este trabalho ao meu pai José Tomas Cocio ("In memorian") que apoiou, aconselhou e foi um grande incentivador da minha trajetória pessoal e profissional. Agradeço a sua força de vontade e empenho por ter sido um excelente pai. Se estou defendendo a minha tese de doutorado, devo todo o sacrificio e amor que o senhor dedicou para que o meu sonho profissional fosse realizado. Lembro de suas palavras referidas a mim em seu leito de morte o quanto orgulhoso estava por eu executar o meu projeto de pesquisa em uma das melhores universidades do país. Se este sonho concretizou, foi o senhor que me proporcionou esta oportunidade de realizá-lo. Agradeço a oportunidade de ter sido o seu filho. Estou muito orgulhoso do senhor. Espero que um dia possamos nos encontrar pois, quero muito te dar um abraço. Eu te amo e só posso dizer um muito obrigado por tudo, Pai! 


\section{Agradecimentos}

Agradeço a minha mãe Aparecida Marcia Giroti Cocio, minha irmã Katia Alessandra Cocio Teles e ao meu cunhado Aníbal Ferreira Teles Neto pelo apoio e dedicação dado a mim por todos estes anos;

Agradeço ao meu orientador Prof. Dr. Roberto Martinez por compartilhar seus conhecimentos e sabedoria na área de micologia clínica, pelas críticas construtivas, pelos conselhos pessoais e profissionais, pela paciência que ajudaram na minha evolução como pessoa e aluno. São conhecimentos que vou levar por toda a minha vida - o senhor é um exemplo a ser seguido;

Agradeço a biologista do Laboratório de Sorologia do Hospital das Clínicas de Ribeirão Preto - Faculdade de Medicina de Ribeirão Preto - HCFMRP/USP Leula Maria de Almeida Pinheiro, por compartilhar o seu conhecimento e pela ajuda na execução de técnicas sorológicas de contraimunoeletroforese e imunodifusão;

Agradeço a todos os funcionários do Laboratório de Sorologia do Hospital das Clínicas de Ribeirão Preto - Faculdade de Medicina de Ribeirão Preto HCFMRP/USP e em especial a biologista encarregada Camila Marques Andrade Nascimento Taveira pela sua ajuda e atenção quando solicitada;

Agradeço a todos os funcionários do Laboratório de Microbiologia e Micologia Clinica do Hospital das Clínicas de Ribeirão Preto - Faculdade de Medicina de Ribeirão Preto - HCFMRP/USP e em especial a biologista encarregada Renata Helena Candido Pocente pela sua ajuda e atenção quando solicitada;

Agradeço a especialista de laboratório da Faculdade de Medicina de Ribeirão Preto - FMRP/USP Margarida Passeri do Nascimento, pela ajuda na execução de técnicas de biologia molecular para identificação genotípica de

Paracoccidioides spp;

Agradeço a secretária da divisão de moléstias infecciosas do Hospital das Clínicas de Ribeirão Preto - Faculdade de Medicina de Ribeirão Preto HCFMRP/USP Ingrid Erbert pela convivência e ajuda ao longo dos anos; 
Agradeço aos meus colaboradores de pesquisa Prof. Dr. Eduardo Bagagli (UNESP - Botucatu, SP), Profa. Dra. Erika Nascimento (Claretiano Centro Universitário - Batatais, SP), Prof. Dr. Gilberto Gambero Gaspar (HCFMRP/USP - Ribeirão Preto, SP) e Profa. Dra. Marcia Regina von Zeska Kress (FCFRP/USP - Ribeirão Preto, SP) pela amizade e conhecimentos compartilhados comigo durante a execução do projeto;

Agradeço ao Prof. Dr. Zoilo Pires de Camargo, Departamento de Microbiologia Imunologia e Parasitologia da Universidade Federal de São Paulo / São Paulo - Brasil por ceder gentilmente as cepas Pbdog - EPM194 e T2 - EPM54 utilizadas neste estudo;

Agradeço o Prof. Dr. Eduardo Alexandre Loth da Universidade Estadual do Oeste do Paraná - Unioeste que gentilmente cedeu os isolados HCRP FOZ_1e HCRP FOZ_2 para identificação genotípica neste estudo;

Agradeço ao Prof. Dr. Rodrigo Santana do departamento de Clinica Médica da Faculdade de Medicina de Ribeirão Preto - FMRP/USP pela amizade e companheirismo ao longo destes anos;

Agradeço a pós - doutoranda Livia Maria Pala Anselmo, do departamento de Clínica Médica da Faculdade de Medicina de Ribeirão Preto - FMRP/USP, pela amizade e companheirismo ao longo destes anos;

Agradeço a aluna de doutorado Patricia Helena Grizante Barião, do departamento de Análises Clínicas, Toxicológicas e Bromatológicas (DACTB) da Faculdade de Ciências Farmacêuticas de Ribeirão Preto - FCFRP/USP, pela amizade e companheirismo ao longo destes anos;

Em especial eu quero agradecer as técnicas de laboratório de Microbiologia e Micologia Clínica do Hospital de Clínicas de Ribeirão Preto - Faculdade de Medicina de Ribeirão Preto - HCFMRP/USP Cristiane Januário Sette, Daniela Maria Vieira Ferracioli Aguetoni, Natália Augusta Barbosa de Freitas e Rachel Geraldi Say pela ajuda na execução do projeto, amizade e companheirismo ao longo destes anos;

Agradeço a Elisabeth Perna, Graziella Ribeiro de Souza, Ricardo Bonfim Silva e Rosane Gomes de Paula Queiroz do laboratório de biologia molecular do 
departamento de Puericultura e Pediatria da Faculdade de Medicina de Ribeirão Preto - FMRP/USP pela ajuda na execução das dosagens de proteinas, realização de eletroforese proteico e fotodocumentação dos géis de agarose (DNA);

Agradecimento especial a Luciana Ambrósio, técnica de laboratório do departamento de Análises Clínicas, Toxicológicas e Bromatológicas (DACTB) da Faculdade de Ciências Farmacêuticas de Ribeirão Preto - FCFRP/USP, pela contribuição e ajuda na quantificação de proteinas;

Agradeço a Profa. Dra. Anamaria Mello Miranda Paniago, a aluna de doutorado Karine Mattos e a Profa. Dra. Simone Schneider Weber do Programa de Pós-graduação em Doenças Infecciosas e Parasitárias da Faculdade de Medicina da Universidade Federal de Mato Grosso do Sul pela amizade, carinho, confiança e colaboração de pesquisa por todos estes anos;

Um agradecimento muito especial a Leila Franco do Nascimento, técnica de laboratório de Microbiologia e Micologia Clínica do Hospital de Clínicas de Ribeirão Preto - Faculdade de Medicina de Ribeirão Preto - HCFMRP/USP e minha primeira aluna de iniciação científica durante o Programa de Aprimoramento Multiprofissional Especializado/CRH/SES-SP em 2019/2020, pela amizade, paciência, carinho e companheirismo durante estes anos;

Agradeço a todos do Hospital das Clínicas de Ribeirão Preto e aos demais laboratórios que com os quais tive contato;

Agradeço a Faculdade de Medicina de Ribeirão Preto-Universidade de São Paulo (FMRP/USP), aos professores, estágios internos e a toda a estrutura que está universidade disponibiliza.

Agradecimento especial aos meus amigos: Felipe Francis Siqueira, Gabriela Francis Siqueira, Gael Gallo Cavenaghi, Giordano Francis Eduardo Siqueira, Marisa Cruz Siqueira, Osmar Cavenaghi, Tathiana Cupaiolo Gallo Cavenaghi pela amizade, convivência e companheirismo ao longo dos anos;

Agradeço a todos que colaboraram direta ou indiretamente para esta pesquisa. 


\section{Epigrafe}

"Os sonhadores morrem mas, o sonho continua vivo."

Trecho retirado da música Empire of the Clouds - Banda: Iron Maiden - Disco: The Book of Souls (2015). 


\section{Apoio Financeiro}

À Coordenação de Aperfeiçoamento de Pessoal de Nivel Superior (CAPES) pela concessão bolsa de doutorado pelo Programa de Excelência Acadêmica (PROEX) e à Fundação de Apoio ao Ensino, à Pesquisa e Assistência do Hospital das Clínicas da Faculdade de Medicina de Ribeirão Preto - USP (FAEPA) pelo suporte financeiro a pesquisa. 
RESUMO

$=$ 


\section{RESUMO}

COCIO, T.A. Identificação molecular e estudo sorológico de isolados clínicos e ambientais de Paracoccidioides spp. do Nordeste do Estado de São Paulo e Sudoeste do Estado de Minas Gerais. 2021. 162f. Tese (Doutorado). Faculdade de Medicina de Ribeirão Preto - Universidade de São Paulo - FMRP/USP. Ribeirão Preto - São Paulo. 2021.

A paracoccidioidomicose ( $\mathrm{PCM}$ ) é uma infecção fúngica sistêmica e endêmica em países da América Latina. A maioria dos casos de PCM ocorrem em grandes áreas no Brasil, compreendendo as regiões Sul, Sudeste e Centro-Oeste do país. O complexo Paracoccidioides brasiliensis (espécies filogenéticas S1a, S1b, PS2, PS3 e PS4) e a espécie $P$. lutzii são os agentes etiológicos da PCM e existem poucos estudos filogenéticos que mostram, de forma incompleta, a distribuição geográfica dessas espécies na América do Sul. Este estudo realizou a identificação molecular de isolados clínicos e ambientais obtidos no Nordeste do Estado de São Paulo e Sudoeste do Estado de Minas Gerais, associando-os com características epidemiológicas e clínicas dos respectivos pacientes com PCM. Também foi avaliada a reatividade de exoantígenos de diferentes espécies do gênero Paracoccidioides spp. produzidos a partir de células miceliais frente a soros de pacientes cujo isolado fúngico foi identificado. Cinquenta amostras de Paracoccidioides spp. foram genotipadas, 46 de origem clínica e predominantemente isoladas na área geográfica de Ribeirão Preto, SP e 4 isolados ambientais coletados na cidade Ibiá, MG, Sudeste do Brasil. Estes isolados foram avaliados por PCR RFLP do gene tub1 e sequenciamento do gp43 exon 2 loci. A espécie $P$. lutzii foi confirmada pelo sequenciamento da região "internal transcribed spacer" (ITS) do DNA ribossomal. Entre os isolados clínicos foram identificados $P$. brasiliensis sensu stricto S1b $(\mathrm{n}=42)$ e S1a $(\mathrm{n}=5), P$. americana (PS2) $(\mathrm{n}=1), P$. restrepiensis (PS3) $(\mathrm{n}=1)$ e $P$. lutzii $(\mathrm{n}=1)$. Todos os isolados ambientais foram caracterizados como $P$. brasiliensis sensu stricto S1b. Não foi encontrada associação entre o genótipo infectante e a forma da doença. O histórico de migração de dois pacientes sugeriu que as infecções por $P$. americana (PS2) e $P$. lutzii ocorreram, respectivamente, nos Estados do Paraná e Mato Grosso. A reatividade dos exoantígenos miceliais de espécies do complexo $P$. brasiliensis e $P$. lutzii, produzidas por cepas de referência e 
clínicas, utilizando as técnicas de imunodifusão dupla (IDD) e contraimunoeletroforese (CIE) foi avaliada frente a 15 soros de pacientes cujo isolado fúngico foi identificado genotipicamente. Observou-se que as frações antigênicas de espécies do complexo $P$. brasiliensis tiveram 100\% de reatividade em ambas as técnicas sorológicas, mas o exoantígeno de $P$. lutzii mostrou baixa reatividade, $53 \%$ em IDD e $20 \%$ em CIE. Os imunoprecipitados obtidos com exoantígenos de espécies do complexo $P$. brasiliensis foram idênticos entre si, mas não mostraram identidade com os precipitados resultantes da reação entre os soros e o exoantígeno $P$. lutzii. Este estudo contribui para o conhecimento da biogeografia de Paracoccidioides spp. e mostra que a análise da distribuição territorial de espécies deste fungo deve considerar a migração humana. Fenotipicamente, enquanto exoantígenos das espécies do complexo $P$. brasiliensis tem antigenicidade similar em teste de imunoprecipitação, o exoantígeno de $P$. lutzii apresentou reatividade quantitativa e qualitativamente distinta, possivelmente pela liberação de fração antigênica peculiar a esta última espécie.

Palavras - chave: Paracoccidioides spp., Paracoccidioidomicose, Espécies filogenéticas, Eco-Epidemiologia, Exoantígenos miceliais, Contraimunoeletroforese, Imunodifusão dupla. 


\section{ABSTRACT}

COCIO, T.A. Molecular identification and serological study of clinical and environmental isolates of Paracoccidioides spp. from the Northeast of the State of São Paulo and the Southwest of the State of Minas Gerais. 2021. 162p. Thesis (Doctorate). Faculty of Medicine of Ribeirão Preto - University of São Paulo FMRP/USP. Ribeirão Preto - São Paulo - SP. 2021

Paracoccidioidomycosis (PCM) is a systemic and endemic fungal infection that occurs in Latin American countries. Most cases of PCM occur in large areas in Brazil, including the South, Southeast and Midwest regions. The Paracoccidioides brasiliensis complex (phylogenetic species S1a, S1b, PS2, PS3 and PS4) and the species $P$. lutzii are the etiological agents of PCM and there are few phylogenetic studies that, incompletely, show the geographic distribution of these species in South America. This study identified molecular genotypes of Paracoccidioides spp. clinical and environmental isolates obtained in the northeast of São Paulo state and the southwest of Minas Gerais state, Brazil. The genotypes were associated with epidemiological and clinical characteristics of the respective PCM patients. It was also evaluated the reactivity of exoantigens from different species of the genus Paracoccidioides spp. produced by reference and clinical strains, mycelial cells that was tested against sera from patients whose fungal isolate was identified. Fifty samples (50) of Paracoccidioides spp. were genotyped, 46 of clinical origin and predominantly isolated in the geographical area of Ribeirão Preto, SP and 4 environmental isolates collected in the Ibiá city, MG, southeastern Brazil. These isolates were evaluated by PCR - RFLP of the tub1 gene and sequencing of gp43 exon 2 loci. The species $P$. lutzii was confirmed by sequencing the internal transcribed spacer (ITS) region of ribosomal DNA. Among the clinical isolates were identified $P$. brasiliensis sensu stricto $S 1 b(n=42)$ and $S 1 a(n=5), P$. americana (PS2) $(n=1), P$. restrepiensis (PS3) $(n=1)$ and $P$ lutzii $(n=1)$. All environmental isolates were characterized as $P$. brasiliensis sensu stricto $\mathrm{S} 1 \mathrm{~b}$. No association was found between the infecting genotype and the form of the disease. The reactivity of the mycelial exoantigens from species of the $P$. brasiliensis complex and $P$. lutzii, produced from reference and clinical strains was evaluated using the techniques of double immunodiffusion (IDD) and counterimmunoelectrophoresis (CIE) against 15 
sera from patients whose fungal isolate was genotypically identified. It was observed that the antigenic fraction of the $P$. brasiliensis complex species had obtained $100 \%$ reactivity in both serological techniques applied but the $P$. lutzii exoantigen showed low serum reactivity of $53 \%$ in IDD and $20 \%$ in CIE. The immune precipitates obtained with exoantigens of the $P$. brasiliensis complex were all identical, but this identity was not verified with the gel precipitates formed between the sera and the $P$. lutzii exoantigens. This study expanded the knowledge of the biogeography of Paracoccidioides spp. and shows that the analysis of the territorial distribution of this fungus species must consider human migration. Phenotypically, exoantigens of the $P$. brasiliensis complex had similar antigenicity in immunoprecipitation test while $P$. lutzii exoantigen presented differences in the aspect and positivity of the precipitate in agar gel, possibly by liberation of an antigenic fraction peculiar to this last species.

Keywords: Paracoccidioides spp., Paracoccidioidomycosis, Phylogenetic species, Eco-Epidemiology, Mycelial exoantigens, Counterimmunoelectrophoresis, Double immunodiffusion. 


\section{LISTA DE FIGURAS}

Figura 1- Distribuição geográfica de Paracoccidioidomicose (PCM) na América Latina e Brasil.................................................................. 1

Figura 2- Propagação dos agentes etiológicos da PCM.................................2

Figura 3- Fluxograma de diagnóstico laboratorial de PCM............................ 4

Figura 4- Distribuição geográfica de espécies do gênero Paracoccidioides spp. na América do Sul e Brasil........................................................ 8

Figura 5- Representação esquemática das placas dos testes sorológicos utilizados neste trabalho................................................................. 35

Figura 6- Amplificação parcial do gene gp43 exon 2 loci por PCR convencional das cepas de referência $(\mathrm{Pb} 18: \mathrm{P}$. brasiliensis sensu stricto (S1b); Pbdog - EPM 194: P. americana (PS2); T2 - EPM 54: $P$. restrepiensis (PS3); Pb_01: $P$. lutzii.) e dos isolados clínicos (001 a 200, FOZ_1, FOZ_2, BAT, BOAS e TONI) e ambientais (IBIÁ, IBIÁT1, IBIÁT2 e IBIÁT3) de avaliados neste estudo para confirmação do gênero Paracoccidioides spp., conforme verificado em gel de agarose $2 \%$

Figura 7- Amplificação do gene tub1 para realização da técnica PCR-RFLP nas cepas de referência e nos isolados clínicos e ambientais de Paracoccidioides spp. Todos os isolados tiveram o gene tub1 amplificado, exceto o isolado HCRP191.

Figura 8- Padrões de fragmentos obtidos após a digestão com as endonucleases $\mathrm{Bcll}$ e $\mathrm{Mspl}$, mostrando similaridade dos isolados clínicos e ambientais com as cepas de referência. (A) Gel de Agarose $3 \%$ com as cepas de referências $\mathrm{Pb} 18: P$. brasiliensis sensu stricto (S1b); Pbdog - EPM 194: P. americana (PS2); T2 EPM 54: $P$. restrepiensis (PS3); Pb_01: $P$. lutzii. (B) Gel de Agarose 3\% com isolados clínicos (001 a 200, FOZ_1, FOZ_2, BAT, BOAS e TONI) e ambientais (IBIÁ, IBIÁT1, IBIÁT2 e IBIÁT3) de Paracoccidioides spp. caracterizados neste estudo. A maioria dos isolados mostrou padrão de digestão enzimática compatível 
com P. brasiliensis sensu stricto (S1), mas os isolados HCRP199 e HCRPBAT tiveram padrão similar, respectivamente, a $P$. americana (PS2) e P. restrepiensis (PS3).

Figura 9- Análise filogenética da região ITS1-5.8S-ITS2 rDNA do isolado HCRP191 em comparação com as cepas de referência $\left(^{*}\right)$; estas também foram sequenciadas para este estudo e tinham 100\% de identidade com as sequências depositadas no GenBank sob o número de acesso: [Pb18 - B17 ( $P$. brasiliensis sensu stricto (S1b)), EPM194 - Pbdog - (P. americana (PS2)) e EPM54 - T2 $(P$. restrepiensis (PS3)) - KT155977.1 para três cepas de referência; Pb01 - EU870297.1 ( $P$. lutzii)] e $H$. capsulatum AMC_HC002 são um grupo externo. A história evolutiva foi medida pelo método de máxima verossimilhança $(\mathrm{ML})$ baseado no modelo de Tamura-Nei. A alta similaridade com Pb01 identifica HCRP 191 como $P$. lutzii..

Figura 10- Análise filogenética gp43 exon 2 loci dos isolados clínicos e ambientais de Paracoccidioides spp. em comparação com as cepas de referência $\left({ }^{*}\right)$; que também foram sequenciadas para este estudo e tinham $100 \%$ de identidade com as sequências depositadas no GenBank sob o número de acesso: [Pb18 - B17 - DQ003729.1 (P. brasiliensis sensu stricto (S1b); EPM194 Pbdog - DQ003736.1 ( $P$. americana (PS2); EPM54 - T2 KT251008.1 ( $P$. restrepiensis (PS3); Pb01 - EU870196.1 ( $P$. lutzii)]. A história evolutiva foi medida pelo método de máxima verossimilhança $(\mathrm{ML})$ com base no modelo Kimura parâmetro

Figura 11- Mapa do Brasil, com destaque para os Estados de São Paulo e Minas Gerais, mostrando a área geográfica centrada por Ribeirão Preto, SP (") ), onde residiam a maior parte dos pacientes, a migração de alguns pacientes que adquiriram a infecção por Paracoccidioides spp. em outras regiões (- - - - - $)$ ) e o local de coleta dos isolados ambientais $(\triangle)$.

Figura 12- Gel de Policrilamida SDS - PAGE 10\% para a avaliação do perfil proteico dos produtos extracelulares de espécies do gênero Paracoccidioides spp. avaliados neste estudo. 
Figura 13- Imunodifusão dupla de exoantígenos miceliais de espécies do complexo $P$. brasiliensis e $P$. lutzii frente a soros 1 a 6 de pacientes com PCM. Soros de pacientes testados de $\mathbf{1}$ a $\mathbf{6}$; Exoantígenos miceliais: A: pool de antígenos obtidos por sonicação de leveduras de Paracoccidioides spp. (Controle); B: Pb18: P. brasiliensis sensu stricto (S1b) - Agitação 60 dias; C: EPM194 - Pbdog: P. americana (PS2) - Estática 30 dias; D: EPM54 - T2: $P$. restrepiensis (PS3) - Estática 60 dias; E: Pb01: $P$. lutzii - Estática 60 dias; B: Pb18 - P. brasiliensis sensu stricto (S1b); C: EPM194 - Pbdog - P. americana (PS2); D: EPM54 - T2 $P$. restrepiensis (PS3); E: Pb01 - $P$. lutzii; F: HCRPBAT $-P$. restrepiensis (PS3); G: HCRP171 - $P$. brasiliensis sensu stricto (S1a); H: HCRP191 - P. lutzii; I: HCRP199 - P. americana (PS2) e $\mathbf{X}$ : poço vazio, sem aplicação de antígenos

Figura 14- Imunodifusão dupla de exoantígenos miceliais de espécies do complexo $P$. brasiliensis e $P$. lutzii frente a soros 7 a 12 de pacientes com PCM. Soros de pacientes testados de 7 a 12; Exoantígenos miceliais: A: pool de antígenos obtidos por sonicação de leveduras de Paracoccidioides spp. (Controle); B: Pb18: P. brasiliensis sensu stricto (S1b) - Agitação 60 dias; C: EPM194 - Pbdog: P. americana (PS2) - Estática 30 dias; D: EPM54 - T2: $P$. restrepiensis (PS3) - Estática 60 dias; E: Pb01: $P$. lutzii - Estática 60 dias; B: Pb18 - P. brasiliensis sensu stricto (S1b); C: EPM194 - Pbdog - P. americana (PS2); D: EPM54 - T2 $P$. restrepiensis (PS3); E: Pb01 - P. lutzii; F: HCRPBAT - $P$. restrepiensis (PS3); G: HCRP171 - $P$. brasiliensis sensu stricto (S1a); H: HCRP191 - P. lutzii; I: HCRP199 - P. americana (PS2) e X: poço vazio, sem aplicação de antígenos

Figura 15- Imunodifusão dupla de exoantígenos miceliais de espécies do complexo $P$. brasiliensis e $P$. lutzii frente a soros 13 a 15 de pacientes com PCM. Soros de pacientes testados de 13 a 15; Exoantígenos miceliais: A: pool de antígenos obtidos por sonicação de leveduras de Paracoccidioides spp. (Controle); B: Pb18: $P$. brasiliensis sensu stricto (S1b) - Agitação 60 dias; C: EPM194 - Pbdog: P. americana (PS2) - Estática 30 dias; D: EPM54 - T2: P. restrepiensis (PS3) Estática 60 dias; E: Pb01: P. lutzii - Estática 60 dias; B: Pb18 - P. brasiliensis sensu stricto (S1b); C: EPM194 - Pbdog - P. americana (PS2); D: EPM54 - T2 - P. restrepiensis (PS3); E: Pb01 - P. lutzii; F: HCRPBAT - $P$. restrepiensis (PS3); G: HCRP171 - $P$. brasiliensis sensu stricto (S1a); H: HCRP191 - P. lutzii; I: HCRP199 - $P$. americana (PS2) e X: poço vazio, sem aplicação de antígenos 


\section{LISTA DE TABELAS}

Tabela 1 - Primers específicos, tamanho dos produtos de PCR, temperaturas de anelamento e referências dos métodos utilizados para a caracterização molecular dos isolados clínicos e ambientais de Paracoccidioides spp. .25

Tabela 2 - Caracterização genotípica dos isolados clinicos de Paracoccidioides spp.: Método de identificação e código de acesso GenBank. 44

Tabela 3 - Forma clínica da PCM, residência dos pacientes e região brasileira onde provavelmente ocorreu a infecção por espécies do complexo $P$. brasiliensis e P. lutzii.

Tabela 4 - Concentração proteica das cepas de referência e clínica de espécies do complexo $P$. brasiliensis e de $P$. lutzii.

Tabela 5 - Perfil proteico e intensidade de expressão dos isolados clínico e de referência de Paracoccidioides spp.

Tabela 6 - Detecção de anticorpos pelo método de imunodifusão dupla (IDD) com uso de exoantigenos miceliais de espécies do gênero Paracoccidioides spp. em soros de pacientes com PCM.

Tabela 7 - Positividade dos soros testados pelo método imunodifusão dupla (IDD) conforme os exoantígenos miceliais de diferentes cepas de referência e clínica de Paracoccidioides spp.

Tabela 8 - Positividade de soros de PCM testados pelo método contraimunoeletroforese $(\mathrm{CIE})$ frente aos exoantígenos miceliais de cepas de referência e clínicas de Paracoccidioides spp. 63

Tabela 9 - Comparação da detecção de anticorpos específicos em cinco soros de PCM conforme as espécies de Paracoccidioides spp. e as técnicas de IDD e CIE. 
LISTA DE ABREVIATURAS 


\section{LISTA DE ABREVIATURAS}

$\%$

Porcentagem

$\times$

Vezes

${ }^{\circ} \mathrm{C}$

Grau Celsius

$\mu \mathrm{g}$

Micrograma

$\mu \mathrm{L}$

Microlitro

$\mu \mathrm{m}$

Micrometro

ARF

ADP ribosylation factor

BAL

Lavagem broncoalveolar

Bcll

Bacillus caldolyticus

CFA

Cell Free Antígens

CHS2

Quitina síntase

CIE

Contraimunoeletroforese

DNA

Ácido desoxirribonucleico

ELISA

Ensaio imunoenzimático

EPM

Escola Paulista de Medicina

FKS

Glucano sintase

g

Grama

gDNA

DNA genômico

gp43 ou GP43

Glicoproteína 43 kDa

$H \& E$

Coloração com hematoxilina e eosina

HCFMRP/USP

Hospital das Clínicas da Faculdade de Medicina de Ribeirão Preto - Universidade de São Paulo

HIV

Vírus da imunodeficiência humana

IDD

Imunodifusão dupla 


\begin{tabular}{|c|c|}
\hline ITS & Espaçador Interno Transcrito \\
\hline $\mathrm{kDa}$ & Unidade de massa atômica \\
\hline $\mathbf{L}$ & Litro \\
\hline M & Molar \\
\hline $\mathrm{m} / \mathrm{v}$ & Relação massa-volume \\
\hline McM & Meio de cultura sintético McVeigh Morton \\
\hline MG & Estado de Minas Gerais \\
\hline mg & Miligrama \\
\hline $\min$ & Minutos \\
\hline $\mathrm{mL}$ & Mililitro \\
\hline MLST & Multi Locus Sequence Typing \\
\hline mm & Milímetro \\
\hline $\mathrm{mM}$ & Milimolar \\
\hline Mspl & Moraxella spp. \\
\hline ng & Nanogramas \\
\hline NGS & New Generation Sequencing \\
\hline $\mathrm{nm}$ & Nanometro \\
\hline $\mathbf{p} / \mathbf{v}$ & Peso / volume \\
\hline PAS & Ácido periódico - Schiff \\
\hline pb & Pares de Bases nitrogenadas \\
\hline PBS & $\begin{array}{l}\text { Salina tamponada com tampão fosfato (Phosphate buffered } \\
\text { saline) }\end{array}$ \\
\hline PCM & Paracoccidioidomicose \\
\hline PCR & Polymerase Chain Reaction \\
\hline PCR - RFLP & $\begin{array}{l}\text { Polymerase Chain Reaction - Restriction Fragment Length } \\
\text { Polymorphism }\end{array}$ \\
\hline
\end{tabular}




\begin{tabular}{ll}
\hline PR & Estado do Paraná \\
PS2 & Paracoccidioides Species 2 \\
PS3 & Paracoccidioides Species 3 \\
PS4 & Paracoccidioides Species 4 \\
qPCR & Polymerase Chain Reaction em tempo real \\
rpm & Rotações por minuto \\
S1 & Species One (1) \\
SP & Estado de São Paulo \\
TBE & Tris - EDTA \\
TEMED & Tetrametil etileno diamina \\
tub1 & a- Tubulina \\
v/v & Volume / volume \\
WB & Western Blotting \\
WGS & Whole Genome Sequencing \\
\hline
\end{tabular}




\section{Sumário}

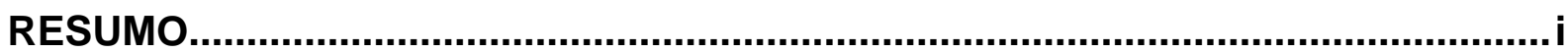

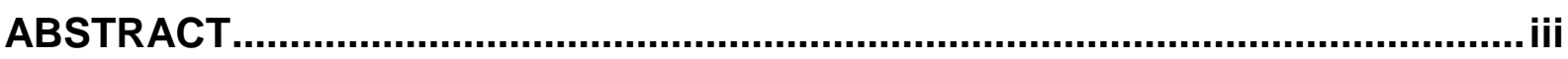



LISTA DE TABELAS ….................................................................................... vii

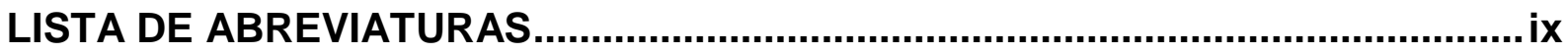



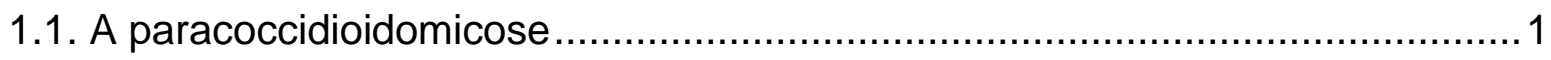

1.2. Biologia molecular aplicada na identificação genotípica de espécies do complexo P. brasiliensis e P. lutzii ............................................................

1.3. Agentes etiológicos da Paracoccidioidomicose $(P C M)$ e sua distribuição

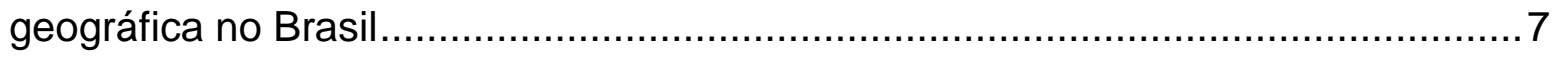

1.4. Aspectos sorológicos e diferenças antigênicas de espécies do complexo $P$. brasiliensis e P. lutzii ................................................................................ 11

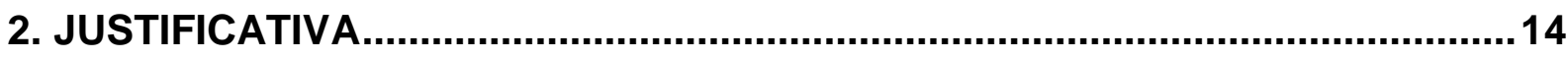

3. OBJETIVOS

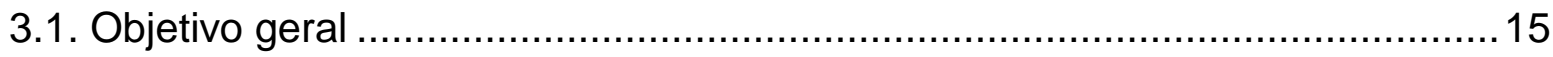

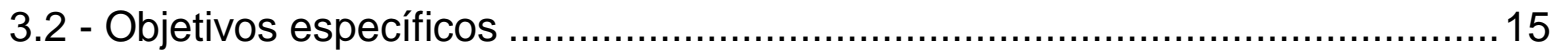

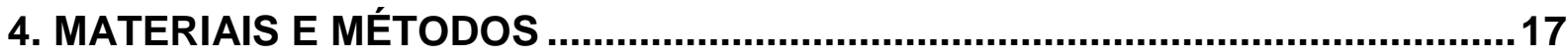

4.1. Isolados clínicos e ambientais de espécies do gênero Paracoccidioides spp. e suas condições de cultivo............................................................................ 17

4.2. Caracterização molecular dos isolados clínicos e ambientais de espécies e variantes pertencentes ao gênero Paracoccidioides spp. .................................... 18

4.2.1. Obtenção de DNA genômico dos isolados clínicos e ambientais de

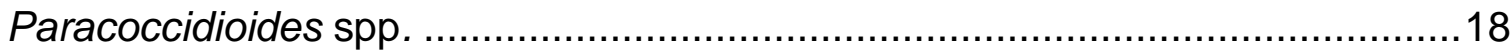

4.2.2. Confirmação do gênero Paracoccidioides spp. nos isolados clínicos e



4.2.3. Caracterização molecular dos isolados clínicos e ambientais do gênero Paracoccidioides spp. utilizando a técnica de Polymerase Chain Reaction Restriction Fragment Length Polymorphism do gene tub1 (tub1 - PCR - RFLP)21

4.2.4. Sequenciamento do gene gp43 exon 2 loci e ITS1-5.8S-ITS2 rDNA dos isolados clínicos e ambientais do gênero Paracoccidioides spp. ........................22

4.3. Análise dos dados epidemiológicos dos pacientes com isolamento fúngico de



4.4. Avaliação da antigenicidade de isolados de Paracoccidioides spp................26 
4.4.1. Produção de exoantigenos da fase micelial de cepas de referência e clínicas de Paracoccidioides spp.

4.4.2. Critério de seleção de exoantígenos miceliais de Paracoccidioides spp. para utilização nos testes de antigenicidade

4.4.3. Precipitação de proteínas a partir das frações miceliais produzidos pelas cepas de referência e clínica das espécies do complexo $P$. brasiliensis e de $P$. lutzii ......

4.4.4. Determinação da concentração de proteínas precipitadas a partir das frações miceliais produzidos das cepas de referência e clínica

4.4.5. Verificação de perfil proteico de exoantígenos miceliais de espécies do gênero Paracoccidioides spp. 30

4.4.6. Verificação de antigenicidade das frações miceliais de espécies do gênero

Paracoccidioides spp. frente a soros de pacientes com PCM .............................32





5. RESULTADOS

5.1. Caracterização molecular dos isolados clínicos e ambientais de



5.1.1. Verificação molecular do gênero Paracoccidioides spp. ..........................37

5.1.2. Identificação das espécies dos isolados clínicos e ambientais de Paracoccidioides spp. pela técnica PCR - RFLP do gene tub1 .........................38

5.1.3. Sequenciamento da região ITS1-5.8S-ITS2 rDNA para identificação de espécies do complexo $P$. brasiliensis e de $P$. lutzii

5.1.4. Análise filogenética utilizando o sequenciamento do gene gp43 exon 2 loci para identificação de espécies e variedades do complexo $P$. brasiliensis e $P$. lutzii 42

5.1.5. Procedência geográfica dos pacientes e forma clínica de PCM. 48

5.2. Avaliação da antigenicidade de exoantígenos miceliais de cepas de referência e isolados clínicos de diferentes espécies do complexo $P$. brasiliensis e de $P$. lutziit2

5.2.1. Seleção dos exoantígenos miceliais produzidos de diferentes cepas de referência e isolados clínicos do gênero Paracoccidioides spp. .52

5.2.2. Concentração proteica dos produtos contendo exoantígenos miceliais de cepas de referência e clínica do gênero Paracoccidioides spp.

5.2.3. Análise de perfil de proteínas extracelulares contendo exoantígenos miceliais de cepas de referência e clínica de espécies do gênero Paracoccidioides spp. 
5.2.4. Antigenicidade dos exoantígenos miceliais produzidos por diferentes espécies de cepas de referência e clínicas de Paracoccidioides spp. frente soros de pacientes

6.1. Espécies filogenéticas de Paracoccidioides spp. isoladas de amostras clínicas e ambientais em área hiperendêmica de paracoccidioidomicose no sudeste do Brasil.

6.1.1. Relação entre os dados genotípicos e epidemiológicos de pacientes com PCM da região e cidade de Ribeirão Preto, SP, Brasil .....

6.2. Antigenicidade de exoantígenos miceliais de espécies do gênero Paracoccidioides spp. 71





9. ANEXOS

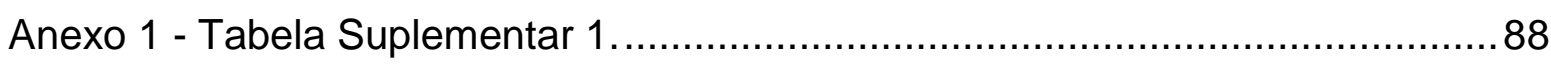

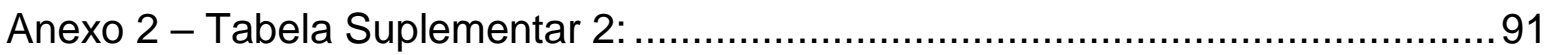

Anexo 3. Comprovante de aprovação do comitê de ética.....................................92

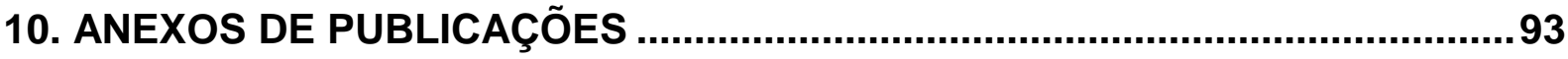

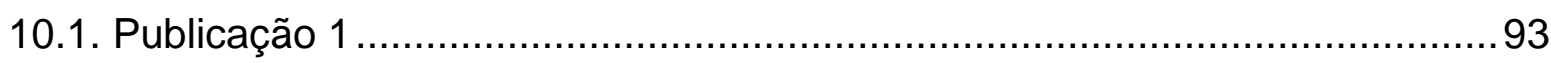

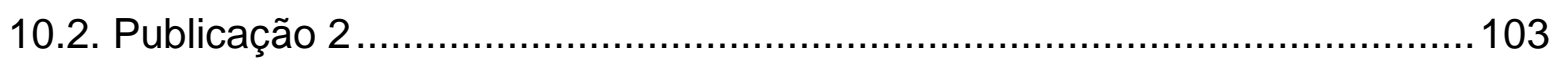

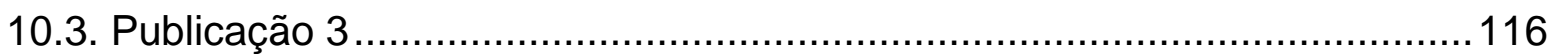


1. INTRODUÇÃO 


\section{INTRODUÇÂO}

\subsection{A paracoccidioidomicose}

A paracoccidioidomicose (PCM) é uma infecção fungica sistêmica endêmica em países da América Latina, como Brasil, Argentina, Colômbia e Venezuela, onde aproximadamente 10 milhões de pessoas já foram infectadas (RESTREPO et al., 2015). Cerca de $80 \%$ dos casos de PCM relatados na América Latina ocorreram no Brasil, principalmente em regiões consideradas endêmicas, como Sudeste, CentroOeste e Sul do país (MARTINEZ, 2017). Em outras áreas localizadas mais ao norte do Brasil, incluindo os estados do Pará, do Maranhão e Tocantins (MATOS et al., 2012), além de Rondônia e Acre (VIEIRA et al., 2014) vem sendo relatados casos de PCM (MARTINEZ, 2017) (Figura 1).

Primeiras áreas reconhecidas com alta endemicidade;

Áreas com alta endemicidade a partir das últimas décadas do século XX:

Áreas com evidência recente de aumento da endemicidade,



Figura 1. Distribuição geográfica de Paracoccidioidomicose (PCM) na América Latina e Brasil. Autoria: Reproduzido e adaptado de Martinez R. New trends in Epidemiology. J. Fungi 2017, 3, 1; doi:10.3390/jof3010001 
A PCM é adquirida por pacientes que diretamente manejam o solo, que possivelmente está contaminado com os propágulos infectantes (artroconídios) dos agentes etiológicos da doença, principalmente em atividades agrícolas como a terraplanagem, preparação do solo, jardinagem e transporte de produtos vegetais (MARTINEZ, 2017; SHIKANAI-YASUDA et al., 2017). Estes propágulos são inalados e dão origem à forma leveduriforme do fungo (patogênica), que constituirão sua forma parasitária nos tecidos e órgãos do hospedeiro (SHIKANAI-YASUDA et al., 2017) (Figura 2).

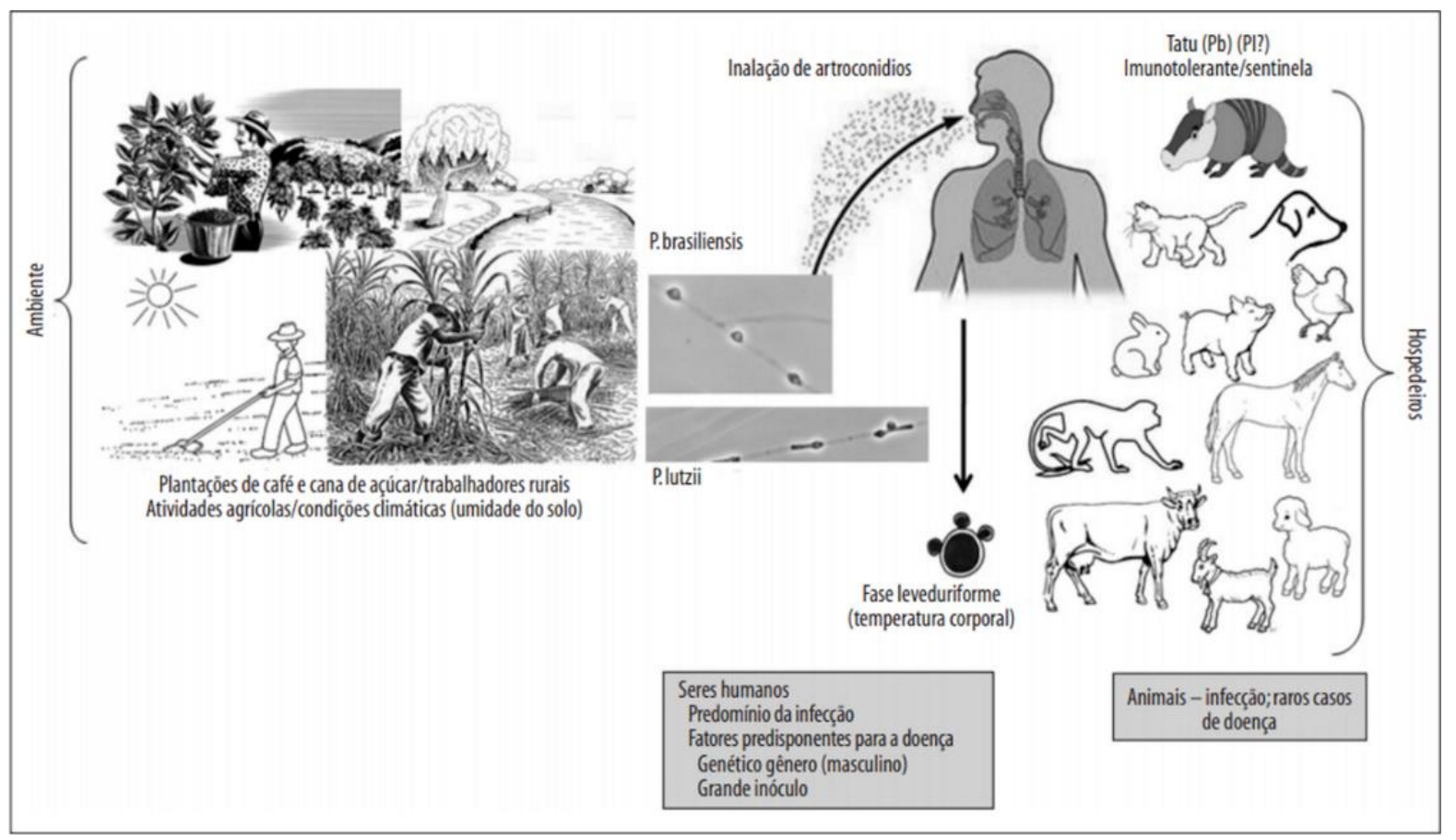

Figura 2. Propagação dos agentes etiológicos da PCM. Autoria: Mendes, R. P. e Bagagli, E. Reproduzido de II Consenso Brasileiro em Paracoccidioidomicose 2017. Epidemiol Serv Saude. 2018 Aug 16;27(spe):e0500001. doi: 10.5123/S167949742018000500001.

A PCM possui duas manifestações com características distintas, a forma aguda e a forma crônica. A forma crônica da PCM é classificada em unifocal e multifocal, acomete principalmente adultos com idade igual ou superior a 30 anos, geralmente pacientes do sexo masculino (MARTINEZ, 2017; SHIKANAI-YASUDA et al., 2017). 
O quadro clínico do paciente tem a característica de avançar cronicamente e pode permanecer restrito aos pulmões causando fraqueza, perda de peso, tosse e dispneia, e podendo ser acompanhando de lesão de mucosa oral e de outros tecidos (SHIKANAI-YASUDA et al., 2017; GONZALEZ \& HERNADEZ, 2016; BELISSIMORODRIGUES et al., 2013). A doença se dissemina para outros órgãos como pele, mucosa orofaríngea, e eventualmente para laringe e outros órgãos, como o sistema nervoso e adrenal (RAMOS E SILVA et al., 2008). A forma aguda da PCM ocorre principalmente em crianças e adultos jovens que representam aproximadamente $10 \%$ dos casos de paracoccidioidomicose (GONZALEZ \& HERNANDEZ, 2016; RESTREPO et al., 2015). O quadro clínico desta forma é caracterizado pela lesão de órgãos como os linfonodos, fígado e baço, além da pele, intestino e ossos. Raramente na fase aguda ocorre a infecção pulmonar propriamente dita e usualmente ocorrem como anemia, perda de peso e febre (GONZALEZ \& HERNANDEZ, 2016; RESTREPO et al., 2015; BELISSIMO-RODRIGUES et al., 2013).

\subsection{Biologia molecular aplicada na identificação genotípica de espécies do complexo $\boldsymbol{P}$. brasiliensis e $\boldsymbol{P}$. Iutzii}

O diagnóstico de PCM realizado em rotina hospitalar é baseado em técnicas consideradas clássicas para a identificação fúngica como, por exemplo, exame micológico direto e a semeadura de amostras clínicas (expectoração, raspagem de pele, aspiração de linfonodo) em cultura, exames histopatológicos, testes bioquímicos e sorológicos (contraimunoletroforese (CIE) e imunodifusão dupla (IDD)) (Figura 3) (PINHEIRO et al., 2020; CAMARGO \& RODRIGUES, 2019). Como complemento ao diagnóstico clássico de identificação fúngica, ensaios envolvendo 
técnicas de biologia molecular podem ser usados para identificar espécies do gênero Paracoccidioides spp. (PINHEIRO et al., 2020; THEODORO et al., 2012).



Figura 3. Fluxograma de diagnóstico laboratorial de PCM. Legenda: BAL: Lavagem broncoalveolar; H\&E: Coloração com hematoxilina e eosina; PAS: ácido periódico Schiff; GMS: Gomori metenamina prata; ELISA: ensaio de imunoabsorção enzimática; DID: imunodifusão dupla; CIE: reação de contraimunoeletroforese; WB: Western blot. Autoria: Reproduzido de Pinheiro, Breno G.; Hahn, Rosane C.; Camargo, Zoilo P.d.; Rodrigues, Anderson M. 2020. "Molecular Tools for Detection and Identification of Paracoccidioides Species: Current Status and Future Perspectives" J. Fungi 6, no. 4: 293. https://doi.org/10.3390/jof6040293

Devido à limitação destas técnicas clássicas utilizadas para a identificação de Paracoccidioides spp. em amostras clínicas e ambientais, viu-se a necessidade de utilizar métodos moleculares para a tal finalidade, como por exemplo a Polymerase Chain Reaction (PCR). Ainda utilizando a PCR convencional como base do método, a PCR - RFLP (Polymerase Chain Reaction - Restriction Fragment Length Polymorphism) foi utilizada como uma técnica alternativa para identificação molecular de isolados clínicos e ambientais de Paracoccidioides spp. Este método 
auxilia na genotipagem utilizando sequências de DNA, loci gênicos polimórficos, gerado pela PCR convencional e, após esta etapa, o produto é digerido por enzimas de restrição específica que geram fragmentos de comprimentos de pares de bases distintos (SAIKI et al., 1985). O primeiro relato da utilização de PCR - RFLP em isolados clínicos de Paracoccidioides spp. coletados de diferentes países da América do Sul (Argentina, Brasil, Colômbia, Peru e Venezuela) foi descrito por Niño - Vega et al. (2000), verificando-se que este método é capaz de identificar as espécies e também diferenciar características filogenéticas entre si. Recentemente, Roberto et al. (2016) utilizaram o gene a - Tubulina (tub1) como produto de PCR, e após esta etapa, o amplicon foi submetido a uma dupla digestão com enzimas de restrição (endonucleases) Bcll de Bacillus caldolyticus e Mspl de Moraxella spp. e observaram que este método tem a capacidade de identificar e separar os agentes etiológicos da PCM, dividindo em espécies crípticas do complexo $P$. brasiliensis e $P$. lutzii (ROBERTO et al., 2016). Este método mostrou-se eficiente para identificar Paracoccidioides spp. e pode ser aplicado diretamente em estudos epidemiológicos da PCM.

Com o advento e aprimoramento de técnicas de biologia molecular aplicada em identificação de Paracoccidioides spp., viu-se a necessidade de entender a relação evolutiva entre estes agentes ao longo do tempo. Uma técnica que responde dúvidas evolutivas (genética populacional) e epidemiológica (origem geográfica) é a Multi Locus Sequence Typing (MLST) (PINHEIRO et al., 2020). São amplificados cinco (5) ou mais genes (nuclear, mitocondrial, estrutural e etc.) por PCR convencional, sequenciados por método de Sanger e realizado um múltiplo alinhamento e análise filogenética das sequências de nucleotídeo para auxiliar na compreensão bioevolutiva do organismo (PINHEIRO et al., 2020). A técnica MLST 
foi aplicada pela primeira em isolados clínicos e ambientais de Paracoccidioides spp. coletados de várias regiões da América Latina por Matute et al. (2006) avaliando diferenças polimórficas de vários genes nucleares como, por exemplo quitina sintase (CHS2), glucano sintase (FKS), a -tubulin (TUB), ADP-ribosylation factor (ARF) e PbGP43 (GP43), sendo proposto que existem espécies crípticas dentro do complexo P. brasiliensis (S1, PS2 e PS3). MLST também foi um método utilizado por Teixeira et al. (2009) que observaram divergências em análises de 13 loci genes polimórficos das três espécies crípticas do complexo $P$. brasiliensis (S1, PS2 e PS3) (MATUTE et al., 2006). Estas divergências foram confirmadas utilizando as técnicas de PCR convencional onde foram amplificados as regiões do Espaçador Transcrito Interno (ITS), seguido de seu sequenciamento e os pesquisadores verificaram diferenças filogenéticas do isolado "Pb01", considerando-o como uma nova espécie denominada de P. lutzii (TEIXEIRA et al., 2009).

Com o surgimento das descrições de espécies crípticas do complexo $P$. brasiliensis e $P$. lutzii, viu-se a necessidade de ampliar os estudos taxonômicos e de variedades genéticas que possam existir no gênero Paracoccidioides spp. A técnica molecular que poderá esclarecer questões bioevolutivas e biogeográficas deste microrganismo é o sequenciamento completo de nova geração, conhecido como Whole Genome Sequencing (WGS) ou New Genome Sequencing (NGS). Muñoz et al. (2016) aplicaram a técnica WGS em isolados clínicos e ambientais isolados de diferentes países da América do Sul, onde observaram diferenças evolutivas entre si propondo a existência de duas variedades na espécie filogenética 1 ( $S 1 a$ e $S 1 b$ ) e uma nova espécie críptica do complexo $P$. brasiliensis, espécie filogenética 4 (PS4), encontrada exclusivamente na Venezuela. Empregando a mesma técnica WGS, Teixeira et al. (2020) avaliaram a diversidade genômica de isolados clínicos 
coletados na Argentina, Brasil, Bolívia, Paraguai, Peru e Venezuela e observaram a presença de espécies pouco frequente em determinadas regiões da América do Sul.

Questionamentos quanto à biologia, estudos epidemiológicos, evolutivos e avaliação da diversidade genética de espécies do gênero Paracoccidioides spp., são respondidos com diferentes tipos de ferramentas que a biologia molecular disponibiliza, mas algumas destas metodologias possuem limitações que podem dificultar o entendimento da frequência genotípica em determinada região.

\subsection{Agentes etiológicos da Paracoccidioidomicose (PCM) e sua distribuição geográfica no Brasil}

Os agentes etiológicos que causam a PCM são fungos termodimórficos pertencentes à família Ajellomycetaceae, ordem Onygenales, da classe Eurotiomycetes, que possuem a capacidade de se desenvolver em duas formas morfológicas distintas, a fase micelial (forma infectante) e a forma leveduriforme (forma patogênica) (GONZALEZ \& HERNANDEZ, 2016). Estudos filogenéticos realizados em agentes etiológicos da PCM identificaram espécies distintas do gênero Paracoccidioides spp (MATUTE et al., 2006; TEIXEIRA et al., 2009).

O clado brasiliensis é composto por cinco espécies filogenéticas sendo S1a e S1b pertencentes ao grupo parafilético distribuído no Brasil, Argentina, Paraguai, Peru e Venezuela; PS2 pertencente ao grupo monofilético distribuído no Brasil e Venezuela e; PS3 pertencente ao grupo monofilético encontrado predominantemente na Colômbia; PS4 grupo monofilético encontrado exclusivamente na Venezuela (MUÑOZ et al., 2016; TEIXEIRA et al., 2014a; CARRERO et al., 2008; MATUTE et al., 2006) (Figura 4). 


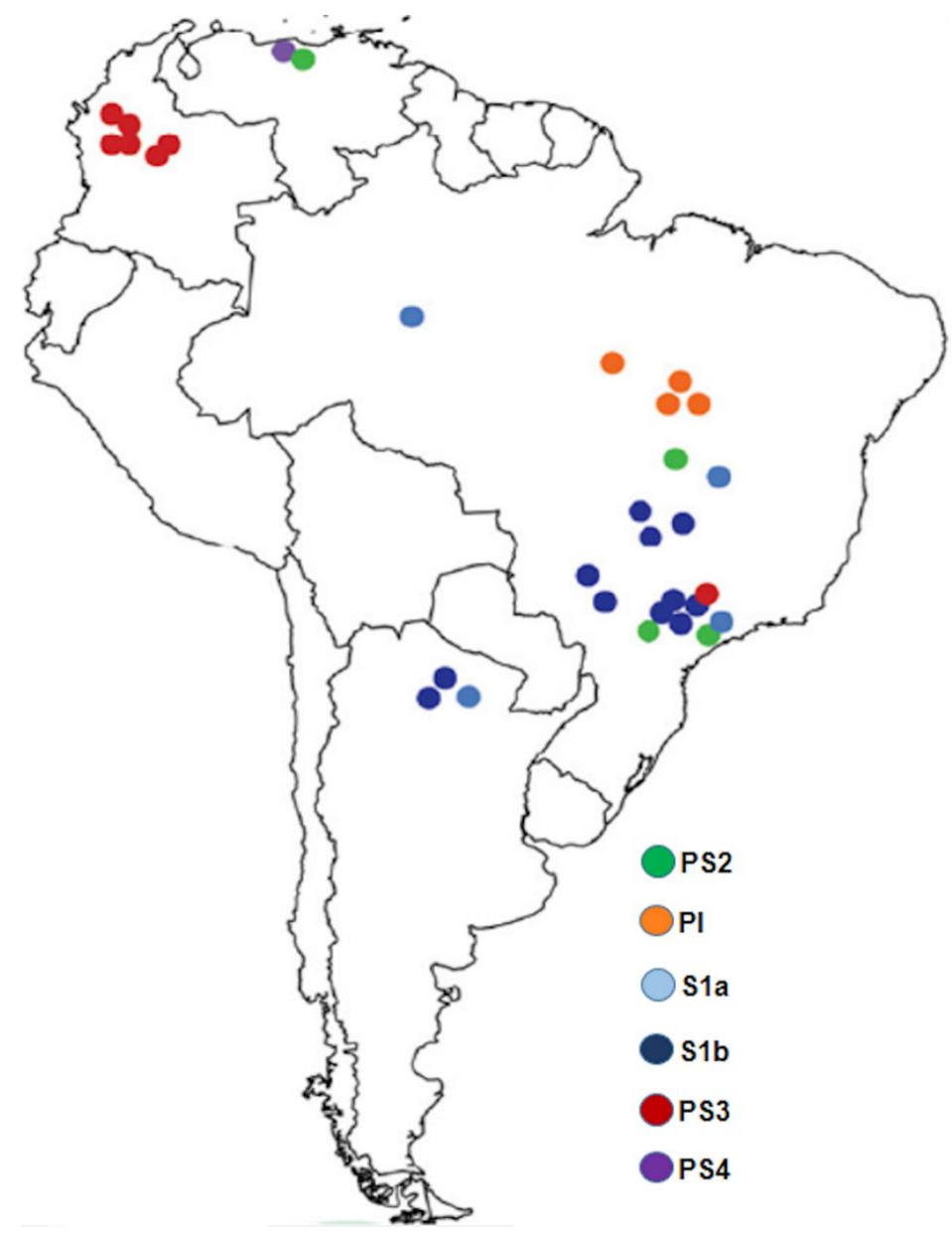

Figura 4. Distribuição geográfica de espécies do gênero Paracoccidioides spp. na América do Sul e Brasil. Legendas: P. americana (PS2) O); P. lutzii (PI) O) P. brasiliensis sensu stricto (S1a) $(\bigcirc)$; $P$. brasiliensis sensu stricto (S1b) $(\bigcirc)$ ); . restrepiensis (PS3) O); P. venezuelensis (PS4) O. Reproduzido e Adaptado de Muñoz e colaboradores. Genome diversity, recombination, and virulence across the major lineages of Paracoccidioides. mSphere 2016; 1(5): e00213-163. doi:10.1128/mSphere.00213-16.

P. lutzii, conhecido anteriormente como 'Pb01' no complexo P. brasiliensis foi considerado uma nova espécie baseada em análises filogenéticas e diferenças nas características morfológicas (TEIXEIRA et al., 2009). Teixeira et al. (2009) observaram que os isolados similares a "Pb01" possuem divergências em análises de 13 loci polimórficos em comparação aos três subgrupos de $P$. brasiliensis $\mathrm{S} 1$, 
PS2 e PS3 (MATUTE et al., 2006). A área endêmica de $P$. lutzii compreende os estados do Mato Grosso e Goiás, região Centro-Oeste do Brasil, e Amazônia (HAHN et al. 2019; MARQUES-DA- SILVA et al. 2012; TEIXEIRA et al. 2014b; THEODORO et al. 2012) (Figura 4).

Turissini et al. (2017) analisaram genes mitocondriais, nucleares e microssatélites propondo quatro novas espécies pertencentes ao gênero Paracoccidioides spp.: P. brasiliensis sensu stricto (S1a e S1b), P. americana (PS2), $P$. restrepensis (PS3), $P$. venezuelensis (PS4), que apresentam divergências genotípicas e micromorfológicas entre si, mas que constituem o complexo $P$. brasiliensis.

Estudos genotípicos indicam que a espécie causadora predominante da PCM no Brasil é $P$. brasiliensis sensu stricto (S1a e S1b). Sua ampla ocorrência geográfica compreende particularmente as regiões Sul e Sudeste do Brasil (Estados de Minas Gerais, São Paulo, Rio de Janeiro, Espirito Santo, Paraná e Rio Grande do Sul) (DE MACEDO et al., 2019; HRYCYK et al., 2018; SHIKANAI-YASUDA et al., 2017; GEGEMBAUER et al. 2014) (Figura 4).

Outra espécie do complexo $P$. brasiliensis que tem sido relatada na literatura como um dos agentes etiológicos da PCM é $P$. americana (PS2), identificadas em isolados do leste do Brasil. Recentemente, este agente etiológico foi relatado em casos de PCM no Estado do Rio de Janeiro, que é considerada uma área endêmica da PCM no Brasil e é encontrado com menor incidência em relação a $P$. brasiliensis sensu stricto (S1) (DE MACEDO et al., 2019; DE MACEDO et al., 2016). Além do estado do Rio de Janeiro, há relatos da presença deste genótipo em estados da região Sul (Rio Grande do Sul e Paraná) (ROBERTO et al., 2016; LENHARD-VIDAL et al. 2013; THEODORO et al. 2012) e região Sudeste (Estado de São Paulo e 
Minas Gerais) (DE MACEDO et al., 2019; HRYCYK et al., 2018; THEODORO et al., 2012; MATUTE et al., 2006).

A espécie filogenética 3 (PS3), agora conhecida como $P$. restrepiensis, foi caracterizada por Matute et al. (2006) e classificada como monofilética, aparentemente restrita à Colômbia e considerada uma linhagem evolutiva independente das outras espécies filogenéticas do complexo $P$. brasiliensis. No entanto, uma amostra deste fungo estudada por Restrepo - Moreno e Scheneidau JD em (1967), isolada de uma paciente que residia na região Sudeste (São Paulo, Brasil), foi identificada anos depois como $P$. restrepiensis (PS3). Recentemente, em pacientes com PCM que residem na cidade de Botucatu, localizada na região centro - oeste do estado de São Paulo, foi identificada a presença de $P$. restrepiensis (PS3) (PEREIRA et al., 2021). Na região Centro - Oeste do Brasil, estado do Mato Grosso do Sul, Mattos et al. (2021) identificaram P. restrepiensis (PS3) em amostras fúngicas isoladas de quatro pacientes locais, mostrando que a ocorrência desta espécie não é mais exclusiva da Colômbia e do estado de São Paulo, SP.

$P$. lutzii, espécie do gênero Paracoccidioides spp., ocorre principalmente na região Centro-Oeste do Brasil nos estados de Mato Grosso, Mato Grosso do Sul e Goiás. Estas áreas são consideradas com maior incidência de PCM causada por $P$. lutzii, mas a distribuição territorial deste agente etiológico ainda não é completamente conhecida (GEGEMBAUER et al., 2014). Há evidências da presença de $P$. lutzii em regiões Sul e Sudeste do Brasil, o qual foi isolado de um paciente que teve somente migração regional (TAKAIAMA et al., 2010). Arantes et al. (2016) observaram a presença de $P$. lutzii em amostras ambientais coletadas em áreas da região Sudeste (estado de São Paulo e Minas Gerais), mostrando a incidência desta 
espécie em uma área distante de sua região endêmica de maior prevalência (região Centro - Oeste) (HAHN et al. 2019).

A determinação da distribuição geográfica das espécies do gênero Paracoccidioides spp. requer estudos com dados epidemiológicos e clínicos, pois fatores importantes como a migração regional e o longo período de latência da PCM podem dificultar o reconhecimento do local exato da infecção e a ocorrência de cada genótipo nas regiões endêmicas de PCM (SHIKANAI-YASUDA et al., 2017; ARANTES et al., 2016).

\subsection{Aspectos sorológicos e diferenças antigênicas de espécies do complexo $P$. brasiliensis e $P$. Iutzii}

Paracoccidioides spp. e outros fungos podem produzir proteínas como, por exemplo, as glicoproteínas e glicoesfingolipídeos, que induzem a uma resposta do sistema imunológico do hospedeiro que pode ser expressa durante a infecção (DA SILVA et al., 2016). Estas moléculas são consideradas possíveis antígenos que os anticorpos de pacientes com PCM podem reconhecer (DA SILVA et al., 2016; CASSOTO, 1990). De acordo com relatos na literatura, alguns antígenos de Paracoccidioides spp. foram caracterizados e identificados a partir de moléculas extraídas da parede celular (antígenos somáticos), antígenos citoplasmáticos (intracelulares) e filtrado de cultura antígenos (exocelulares ou exoantígenos) ou cell free antigens (CFA - exoantígenos) (DA SILVA et al., 2016; CAMARGO et al., 2003; FAVA-NETTO, 1984; SAN-BLAS \& SAN-BLAS, 1989; DE CAMARGO et al., 1988; YARZÁBAL, 1982).

Os laboratórios de rotina hospitalar que executam técnicas sorológicas para o diagnóstico de PCM possuem grandes dificuldades em produzir os antígenos 
fúngicos devido à complexidade das etapas dos métodos para obter estas moléculas (DE CAMARGO, 2008). Ainda não há uma produção de antígenos que possam ser considerados padrão ouro para execução dos testes sorológicos (VIDAL et al., 2014). O método de produção de antígenos de Paracoccidioides spp. e de $P$. lutzii utilizado com mais frequência em laboratórios de pesquisa é o que envolve a liberação de proteínas extracelulares (exoantígenos), como CFA e o filtrado de cultura de células leveduriformes de Paracoccidioides spp. (GEGEMBAUER et al., 2014; DE CAMARGO, 2008). Como alternativa à produção de exoantígenos de Paracoccidioides spp., células miceliais vem sendo utilizadas para obter estas moléculas. O primeiro relato da obtenção de exoantígenos por meio de células miceliais de Paracoccidioides spp. foi descrito por Silva - Vergara et al. (2000), onde fragmentos de micélios de isolados clínicos foram inoculados em um meio de cultura liquido sintético e crescidos em temperatura ambiente. Observou-se reação antigênica dos exoantígenos miceliais frente a soros coletados de camundongos (SILVA - VERGARA et al., 2000). Bellíssimo - Rodrigues et al. (2010) avaliaram soros de pacientes diagnosticados com PCM e co - infecção por HIV utilizando exoantígenos miceliais por meio da técnica de imunodifusão dupla (IDD). Estes estudos mostram a existência de alternativa para a produção de antígenos de PCM utilizando a fase micelial (infectante) de Paracoccidioides spp.

Estudos comparativos de exoantígenos obtidos de células leveduriformes das espécies do complexo $P$. brasiliensis e $P$. lutzii, utilizando as técnicas de CFA e o filtrado de cultura, foram avaliados ao longo do tempo. Lacaz et al., (1999) compararam exoantígenos obtidos do isolado ambiental lbiá $(P$. brasiliensis sensu stricto (S1b)) e o clínico BAT ( $P$. restrepiensis (PS3)) encontrando diferenças quanto à fração proteica extracelular produzida por estas espécies do gênero 
Paracoccidioides spp. Em um estudo utilizando exoantígenos de espécies do complexo $P$. brasiliensis ( $P$. brasiliensis sensu stricto (S1) e $P$. restrepiensis (PS3)) e P. Iutzii, Machado et al. (2013) compararam a antigenicidade frente a soros de pacientes da região Sudeste (estado de São Paulo) e Centro - Oeste (estado do Mato Grosso) do Brasil. Exoantígeno da espécie P. restrepiensis (PS3) obteve maior eficácia contra os soros testados e também apresentou um perfil proteico que destacou a alta expressão de GP43 em relação a $P$. lutzii e outras espécies do complexo P. brasiliensis (MACHADO et al., 2013).

Exoantígenos obtidos de espécies do complexo $P$. brasiliensis e $P$. lutzii foram avaliados para observar diferenças de perfil proteico extracelulares e na antigenicidade. Gegembauer et al. (2014) avaliaram exoantígenos obtidos de isolados clínicos de $P$. lutzii e comparando a reatividade sorológica com espécie do complexo $P$. brasiliensis ( $P$. brasiliensis sensu stricto (S1b) e $P$. restrepiensis (PS3)): exoantígenos $P$. lutzii obtiveram porcentagem maior de soro reatividade frente a soros de pacientes cujo o isolado fúngico foi identificado como $P$. lutzii, em comparação a exoantígenos produzidos de cepas de espécies do complexo $P$. brasiliensis (GEGEMBAUER et al., 2014). Este resultado sorológico foi observado em estudos que avaliaram soros de pacientes coletados de vários centros médicos localizados na região Centro - Oeste do Brasil (estados do Mato Grosso e Mato Grosso do Sul) e Sudeste (estado de São Paulo), respectivamente, corroborando com os dados literários que sugerem que exoantígenos proveniente da espécie $P$. lutzii possui frações proteicas e reação antigênica diferentes de espécies do complexo P. brasiliensis (MATTOS et al., 2021; PEREIRA et al., 2020; DE ARRUDA GROSSKLAUS et al., 2016; QUEIROZ JUNIOR et al., 2014). 
A comparação da reatividade de exoantígenos de células miceliais de diferentes espécies de Paracoccidioides spp. pode contribuir para distinguir fenotipicamente tais espécies e produzir dados adicionais para esclarecer a variabilidade na detecção de anticorpos de acordo com a espécie e cepa produtora de antígeno e com a região geográfica de procedência do soro e de residência do paciente com PCM. 
2. JUSTIFICATIVA 


\section{JUSTIFICATIVA}

O intuito deste projeto foi realizar uma avaliação genotípica e da antigenicidade de isolados de Paracoccidioides spp. de pacientes da região e cidade de Ribeirão Preto, localizada no Nordeste do Estado de São Paulo, que foram tratados no Hospital das Clínicas de Ribeirão Preto - Faculdade de Medicina de Ribeirão Preto - Universidade de São Paulo, HCFMRP/USP. A macrorregião de Ribeirão Preto é uma área hiperendêmica de PCM e se destaca por percentuais relativamente elevados de pacientes com a forma aguda/subaguda e também de acometimento de mulheres (BELISSIMO-RODRIGUES et al., 2011).

A identificação genotípica das espécies do complexo $P$. brasiliensis e de $P$. lutzii na região e cidade de Ribeirão Preto, SP, Brasil, busca preencher lacuna no conhecimento de distribuição geográfica dessas espécies e também permitirá estabelecer sua relação com as formas clínicas de PCM e comparar a respectiva antigenicidade frente ao soros dos doentes.

Exoantígenos miceliais produzidos por diferentes espécies do complexo $P$. brasiliensis e $P$. lutzii e testados frentes a soros de pacientes, podem ser uma alternativa interessante para mostrar similaridades e diferenças fenotípicas entre tais espécies.

A identificação de espécies do complexo $P$. brasiliensis e $P$. lutzii no Sudeste do Brasil, juntamente com dados epidemiológicos dos pacientes contribuirá para entender a propagação destes agentes etiológicos da PCM no território brasileiro. 
3. OBJETIVOS 


\section{OBJETIVOS}

\subsection{Objetivo geral}

Caracterizar genotipicamente espécies e variantes de Paracoccidioides spp. isoladas de pacientes da região e cidade de Ribeirão Preto, SP, Brasil, relacionando os resultados com aspectos epidemiológicos e clínicos da PCM, assim como avaliar a reação de soros destes pacientes frente a exoantígenos produzidos pela fase micelial de espécies do complexo $P$. brasiliensis e de $P$. lutzii identificados por métodos moleculares.

\section{2 - Objetivos específicos}

1. Genotipagem de isolados clínicos e ambientais de Paracoccidioides spp por meio de técnicas de biologia molecular, incluindo: o sequenciamento do gene gp43 exon 2 loci e região ITS1-5.8S-ITS2 rDNA e a realização da técnica Polymerase Chain Reaction - Restriction Fragment Length Polymorphism do gene tub1 (tub1 - PCR RFLP);

2. Análise filogenética, para a avaliação evolutiva, dos isolados clínicos e ambientais de Paracoccidioides spp. a partir dos nucleotídeos reconhecidos pelo sequenciamento de gp43 exon 2 loci e região ITS1-5.8S-ITS2 rDNA;

3. Relacionar os dados genotípicos obtidos pela caracterização molecular dos isolados clínicos de Paracoccidioides spp. com os dados epidemiológicos e clínicos dos pacientes de PCM; 
4. Preparação de exoantígenos miceliais de cepas de referência e clínicas que representam espécies do complexo $P$. brasiliensis e $P$. lutzii e avaliar frações e concentrações de proteínas nessas amostras;

5. Avaliar a reação dos exoantígenos miceliais de espécies do gênero Paracoccidioides spp. frente a soros de pacientes com PCM cujo isolado fúngico foi identificado;

6. Comparar a reatividade dos exoantígenos pelos métodos de imunodifusão dupla (IDD) e contraimunoeletroforese (CIE). 
4. MATERIAIS E MÉTODOS 


\section{MATERIAIS E MÉTODOS}

\subsection{Isolados clínicos e ambientais de espécies do gênero Paracoccidioides spp. e suas condições de cultivo}

Para os estudos genotípicos e sorológicos utilizados neste estudo foram avaliados isolados fúngicos do gênero Paracoccidioides spp. oriundos de amostras clínicas de pacientes atendidos no Hospital das Clínicas da Faculdade de Medicina de Ribeirão Preto - Universidade de São Paulo (HCFMRP/USP) no período de 1975 a 2019, no total de quarenta e quatro (44); dois (2) isolados clínicos da região de Foz do Iguaçu - Estado do Paraná - PR; e quatro (4) cepas ambientais coletados na cidade de Ibiá - Minas Gerais - MG (SILVA - VERGARA et al., 1998; SILVA VERGARA et al., 2000) (Anexo 1 - Tabela Suplementar 1).

Previamente os isolados clínicos e ambientais foram classificados como pertencentes ao gênero Paracoccidioides spp. por meio de testes clássicos de identificação fúngica, incluindo caracterizações macroscópica, microscópica e termodimorfismo, realizados no Laboratório de Micologia do HCFMRP/USP. Os isolados de referência utilizados para a identificação molecular e testes sorológicos foram as cepas Pb18 (coleção do Laboratório de Investigação em Micologia Médica da Faculdade de Medicina de Ribeirão Preto), representante da espécie $P$. brasiliensis sensu stricto (S1b); Pbdog - EPM 194, representante da espécie $P$. americana (PS2) (ROBERTO et al, 2016); T2 - EPM 54, representante da espécie $P$. restrepiensis (PS3) (ROBERTO et al., 2016) e Pb01 que representa a espécie $P$. lutzii (TEIXEIRA et al., 2009). Estas cepas foram mantidas por repiques sucessivos em meio Ágar Sabouraud Dextrose (Oxoid ${ }^{\circledR}$ LTD - Thermo Fisher Scientifc ${ }^{\circledR}$, Basingstoke, Hampshire, England) acrescido $0,15 \mathrm{~g} / \mathrm{l}$ de succinato sódico de cloranfenicol (Blau Farmacêutica, Florianópolis, Brasil) e incubadas a $25^{\circ} \mathrm{C}$. 


\subsection{Caracterização molecular dos isolados clínicos e ambientais de espécies e variantes pertencentes ao gênero Paracoccidioides spp.}

4.2.1. Obtenção de DNA genômico dos isolados clínicos e ambientais de Paracoccidioides spp.

Para obter o DNA genômico (gDNA) dos isolados clínicos e ambientais avaliados neste estudo foram inoculados fragmentos de micélio em meio de cultura liquido sintético e modificado McVeigh e Morton (McM), descrito por Restrepo e Jimenez (1980), e incubados por 35 dias em temperatura constante de $25^{\circ} \mathrm{C}$, em um agitador orbital a 130 rpm (Infors HT - Ecotron ${ }^{\circledR}$, Bottmingen, Suíça). Após o período de crescimento fúngico, os micélios desenvolvidos foram coletados utilizando filtro Falcon $^{\circledR}$ Cell Strainer 40um Nylon (Corning ${ }^{\circledR}$, Tewksbury, MA, Estados Unidos) e submetidos a extração de gDNA conforme o método I (pérola de vidro tratada/fenolclorofórmio/álcool isoamilíco), com mínimas modificações, descrito por van Burik et al. (1998).

Aproximadamente $150 \mathrm{mg}$ de micélio dos isolados clínicos e ambientais avaliados neste estudo foram coletados e congelados em nitrogênio líquido. Após o congelamento, a massa micelial a ter extraído o gDNA foi adicionada em um tubo de microcentrífuga de $1,5 \mathrm{~mL}$ estéril (Corning ${ }^{\circledR}$, Tewksbury, MA, Estados Unidos) juntamente com $500 \mu \mathrm{L}$ pérola de vidro de vidro estéril (Sigma Aldrich ${ }^{\circledR}$, Inc. - St. Louis, MO, Estados Unidos) tratadas com ácido nítrico (Merck ${ }^{\circledR}$, Darmstadt, Alemanha) e $400 \mu \mathrm{L}$ de tampão de extração em um tubo de microcentrífuga de 1,5 $\mathrm{mL}$ estéril. Após este procedimento, as amostras foram agitadas vigorosamente em um agitador de tubos "vortex" (Nova ${ }^{\circledR}$, Piracicaba, SP, Brasil) por trinta segundos (30s) e em seguida resfriadas utilizando um recipiente com gelo (temperatura aproximadamente de $4^{\circ} \mathrm{C}$ ) por dois minutos $(2 \mathrm{~min}$.). Este procedimento foi repetido 
por 5 vezes. Ao término desta etapa a suspensão (célula e tampão de extração) foi transferida para um novo tudo de microcentrífuga de $1,5 \mathrm{~mL}$ estéril (Corning ${ }^{\circledR}$, Tewksbury, MA, Estados Unidos) e adicionado $500 \mu \mathrm{L}$ de tampão de extração e incubada a $65^{\circ} \mathrm{C}$ por 1 hora. Após o período de incubação, foi adicionado 0,5 volume de fenol / clorofórmio / álcool isoamilíco (24:24:1) previamente resfriado a temperatura de $4^{\circ} \mathrm{C}$, ambos da fabricante (Sigma Aldrich ${ }^{\circledR}$, Inc. - St. Louis, MO, Estados Unidos) e centrifugada a 12000 rpm a $4^{\circ} \mathrm{C}$ por 5 minutos (Eppendorf ${ }^{\circledR}$, Hamburgo, Alemanha). O sobrenadante foi retirado e transferido para um novo tubo de microcentrífuga de 1,5 mL estéril (Corning ${ }^{\circledR}$, Tewksbury, MA, Estados Unidos) e em seguida adicionado 0,5 volumes de clorofórmio / álcool isoamilíco (24:1) à temperatura de $4^{\circ} \mathrm{C}$ ambos da fabricante (Sigma Aldrich ${ }^{\circledR}$, Inc. - St. Louis, MO, Estados Unidos), etapa esta repetida 4 vezes. O sobrenadante foi coletado e transferido para um novo tubo de microcentrífuga de $1,5 \mathrm{~mL}$ estéril (Corning ${ }^{\circledR}$, Tewksbury, MA, Estados Unidos) e adicionado 2 volumes de etanol 100\% (Merck ${ }^{\circledR}$, Darmstadt, Alemanha) e 0,1 volume de Acetato de Sódio 10M (Sigma Aldrich ${ }^{\circledR}$, Inc. St. Louis, MO, Estados Unidos), ambos previamente resfriados à temperatura de $4^{\circ} \mathrm{C}$. Após, as amostras foram incubadas a uma temperatura de $-80^{\circ} \mathrm{C}$ por 24 horas e em seguida centrifugadas a 12000 rpm por 20 minutos à temperatura de $4^{\circ} \mathrm{C}$ (Eppendorf ${ }^{\circledR}$, Hamburgo, Alemanha). O sobrenadante foi descartado e o material genético precipitado como "pellet" foi lavado com etanol 70\% (Merck ${ }^{\circledR}$, Darmstadt, Alemanha) pelo método de centrifugação a 12000 rpm por 10 minutos a $4^{\circ} \mathrm{C}$ (Eppendorf, Hamburgo, Alemanha). O etanol 70\% foi completamente retirado da amostra por evaporação em temperatura ambiente e o precipitado ("pellet") ressuspendido em $50 \mu \mathrm{L}$ de água ultra pura esterilizada (Millipore ${ }^{\circledR}$, Burlington, MA, EUA). 
Após a extração, o DNA genômico foi submetido a um tratamento com RNase $A^{\circledR}$ (Thermo Fisher Scientifc Inc ${ }^{\circledR}$, Waltham, MA, Estados Unidos) na concentração de $300 \mathrm{ng} / \mu \mathrm{L}$, à $37^{\circ} \mathrm{C}$ por uma hora. A concentração do DNA genômico foi determinada através da utilização do NanoDrop $2000{ }^{\circledR}$ (Thermo Fisher Scientifc Inc ${ }^{\circledR}$, Waltham, MA, Estados Unidos) e sua integridade verificada em gel de agarose $1 \%$ diluído em tampão TBE 1x, utilizando marcador de peso molecular de $1 \mathrm{~Kb}$ Gene Ruler $^{\circledR}$ (Thermo Fisher Scientifc Inc ${ }^{\circledR}$, Waltham, MA, Estados Unidos), o intercalante de DNA SYBR ${ }^{\circledR}$ Safe DNA gel stain (Thermo Fisher Scientifc Inc ${ }^{\circledR}$, Waltham, MA, Estados Unidos) e visualizado no fotodocumentador ChemiDoc ${ }^{\mathrm{TM}} \mathrm{XRS}+$, utilizando o software Image Lab ${ }^{\text {TM }}$ (Bio - Rad ${ }^{\circledR}$, Hercules, CA, Estados Unidos).

\subsubsection{Confirmação do gênero Paracoccidioides spp. nos isolados clínicos e ambientais}

Cinquenta (50) gDNA dos isolados clínicos, ambientais e mais as cepas de referência avaliadas neste estudo foram submetidos a uma PCR convencional com o par de primers que amplificam o gene gp43 exon 2 loci (Tabela 1). Este gene codifica o antígeno 43-kDa glicoproteína imunodominante (GP43) e foi amplificado com o intuito de identificar e averiguar se os isolados realmente pertenciam ao gênero Paracoccidioides spp. Esta etapa foi realizada de acordo com a metodologia descrita por Cisalpino e colaboradores (1996). A reação de PCR foi realizada com o termociclador vapo.protect ${ }^{\circledR}$ (Eppendorf ${ }^{\circledR}$, Hamburgo, Alemanha) e a enzima Taq polimerse - GoTaq ${ }^{\circledR}$ Green Master Mix (Promega ${ }^{\circledR}$, Madison, WI, Estados Unidos), conforme instrução do fabricante. O volume final da reação de PCR foi de $25 \mu \mathrm{L}$, contendo $500 \mathrm{ng} / \mu \mathrm{L}$ de gDNA de cada isolado analisado. Os produtos da PCR, de tamanho aproximado 533 pb, tiveram a sua integridade verificada em gel de agarose 
2\% diluído em tampão TBE $1 \times$ utilizando o intercalante de DNA SYBR ${ }^{\circledR}$ Safe DNA gel stain (Thermo Fisher Scientifc Inc ${ }^{\circledR}$, Waltham, MA, Estados Unidos), marcador de peso molecular 100 bp Ladder, Ready-To-Use (Sinapse ${ }^{\circledR}$ Inc, Estados Unidos), seguida de visualização e fotografia no fotodocumentador ChemiDoc ${ }^{\mathrm{TM}} \mathrm{XRS}+\mathrm{e}$ o software Image Lab ${ }^{\text {TM }}$ (Bio - Rad®, Hercules, CA, Estados Unidos).

\subsubsection{Caracterização molecular dos isolados clínicos e ambientais do gênero Paracoccidioides spp. utilizando a técnica de Polymerase Chain Reaction - Restriction Fragment Length Polymorphism do gene tub1 (tub1 - PCR - RFLP)}

A caracterização molecular dos isolados clinicos e ambientais avaliados neste estudo foi determinada com a utilização da técnica Polymerase $\underline{\text { Chain }}$ Reaction -

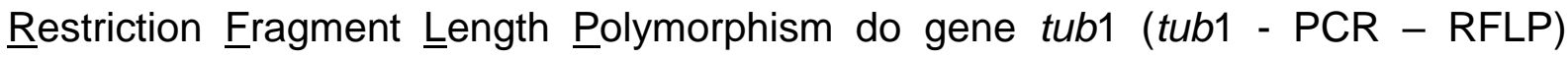
descrita por Roberto et al. (2016), com mínimas modificações. As reações de tub1 PCR-RFLP foram realizadas com o termociclador vapo.protect ${ }^{\circledR}$ (Eppendor $^{\circledR}$, Hamburgo, Alemanha) e a enzima Taq polimerse - GoTaq $^{\circledR}$ Green Master Mix (Promega ${ }^{\circledR}$, Madison, WI, Estados Unidos), conforme instrução do fabricante. O volume final da reação de PCR foi de $25 \mu \mathrm{L}$, contendo $500 \mathrm{ng} / \mu \mathrm{L}$ de DNA genômico e utilizando primers na concentração de $10 \mathrm{mM}$ e temperatura de anelamento que estão descritos na Tabela 1. Os produtos da PCR tub1, tamanho aproximado de 263 pares de bases $(\mathrm{pb})$, foram submetidos a dupla digestão com as endonucleases $B c / l$ e Mspl (Thermo Fisher Scientifc Inc ${ }^{\circledR}$, Waltham, MA, Estados Unidos) na concentração de $10 \mathrm{U} / \mu \mathrm{L}$ cada a $37^{\circ} \mathrm{C}$ por 16 horas, conforme instrução do fabricante. Os fragmentos gerados após a dupla digestão enzimática, foram comparados conforme descrito por Roberto et al. (2016) e visualizados em gel de agarose $3 \%$ diluído em tampão TBE $1 \times$ a $70 \mathrm{~V}$ por 140 minutos na presença de 
SYBR $^{\circledR}$ Safe DNA gel stain (Thermo Fisher Scientifc Inc ${ }^{\circledR}$, Waltham, MA, Estados Unidos) e marcador de peso molecular de 50 bp DNA ladder (Sinapse ${ }^{\circledR}$ Inc, Estados Unidos) seguida de visualização e fotografia no fotodocumentador ChemiDoc $^{\mathrm{TM}}$ XRS+ e o software Image Lab ${ }^{\mathrm{TM}}$ (Bio - Rad®, Hercules, CA, Estados Unidos).

Cepas não identificadas pela técnica de tub1 - PCR - RFLP foram submetidas ao sequenciamento da região ITS1-5.8S-ITS2 rDNA para a caracterização genotípica em espécies do complexo $P$. brasiliensis e ou $P$. lutzii.

\subsubsection{Sequenciamento do gene gp43 exon 2 loci e ITS1-5.8S-ITS2 rDNA dos isolados clínicos e ambientais do gênero Paracoccidioides spp.}

Para o sequenciamento de gp43 exon 2 loci para diferenciar espécies e variantes do gênero Paracoccidioides spp. e da região ITS1-5.8S-ITS2 rDNA de isolados cujo genótipo não foi identificado pelo método tub1 - PCR - RFLP, o gDNA de cada amostra clínica e ambiental foi submetido a uma PCR convencional utilizando o termociclador vapo.protect ${ }^{\circledR}$ (Eppendor ${ }^{\circledR}$, Hamburgo, Alemanha) e a enzima Taq polimerse - GoTaq ${ }^{\circledR}$ Green Master Mix (Promega ${ }^{\circledR}$, Madison, WI, Estados Unidos), conforme instrução do fabricante. $O$ volume final da reação de PCR foi de $25 \mu \mathrm{L}$, contendo $500 \mathrm{ng} / \mu \mathrm{L}$ de gDNA e utilizados primers na concentração de 10 mM e temperatura de anelamento de acordo com a descrição na Tabela 1. Os produtos de PCR de gp43 exon 2 (722 pb) e ITS1-5.8S-ITS2 rDNA (633 pb) foram visualizados em gel de agarose $2 \%$ diluído em tampão TBE 1x a 70V por 60 minutos na presença de SYBR ${ }^{\circledR}$ Safe DNA gel stain (Thermo Fisher Scientifc Inc ${ }^{\circledR}$, Waltham, MA, Estados Unidos) e marcador de peso molecular de 100 bp DNA ladder (Sinapse ${ }^{\circledR}$ Inc, Estados Unidos) seguida de visualização no fotodocumentador ChemiDoc $^{\mathrm{TM}}$ XRS+ e o software Image Lab ${ }^{\mathrm{TM}}$ (Bio - Rad®), Hercules, CA, Estados 
Unidos). Não ocorrendo amplificações inespecíficas, os amplicons foram purificados utilizando o kit Wizard ${ }^{\circledR}$ SV Gel and PCR Clean-UP System (Promega, Madison, WI, Estados Unidos), conforme instrução do fabricante, para retirada de impurezas que possam interferir no processo de sequenciamento genômico.

As sequências de nucleotídeos de cada isolado clínico e ambiental de Paracoccidioides spp. foram determinadas utilizando a plataforma do Centro de Pesquisa do Genoma Humano e Célula Tronco do Instituto de Biociências da Universidade de São Paulo (CEGH-CEL/IB-USP) com o sequenciador ABI3730 DNA Analyzer $^{\circledR}$ (Applied Biosystems, Foster City, CA, Estados Unidos) e empregando o BigDye $^{\circledR}$ Terminator v3.1 Cycle Sequencing Kit (Thermo Fisher Scientifc Inc ${ }^{\circledR}$, Waltham, MA, Estados Unidos), conforme instrução do fabricante. Os cromatogramas da região ITS1-5.8S-ITS2 rDNA e do gene gp43 exon 2 loci, foram analisadas com o software ChromasPro $^{\circledR}$ (ChromasPro ${ }^{\circledR}$ 2.6.5, Technelysium Pty Ltd, Tewantin QLD, Austrália) gerando arquivo .fasta. Cada arquivo representando as sequências de DNA de cada amostra de Paracoccidioides spp. foi comparado com a base de dados de nucleotídeos utilizando a ferramenta BLASTn - Basic Local Alignment Search Tool: https://blast.ncbi.nlm.nih.gov/Blast.cgi (ALTSCHUL et al., 1990), para a identificação de espécies e variedades de Paracoccidioides spp.

\subsubsection{Análises filogenéticas da região ITS1-5.8S-ITS2 rDNA e do gene gp43 exon 2 loci dos isolados clínicos e ambientais de Paracoccidioides spp.}

A análise filogenética dos isolados clínicos e ambientais de Paracoccidioides spp. foi realizada utilizando o método de máxima verossimilhança $(\mathrm{ML})$, onde o modelo evolutivo Tamura - Nei foi aplicado nas sequências ITS1-5.8S-ITS2 rDNA e o modelo Kimura 2 - parameter nas sequências de gp43 exon 2 loci, ambos com 
bootstrap de 1000 replicações conforme metodologia descrita por Hrycyk et al. (2018) e utilizando o software MEGA 6.0 (Molecular Evolutionary Genetics Analysis) (TAMURA et al., 2013). Na análise filogenética da região ITS1-5.8S-ITS2 rDNA foi incluída a sequência de Histoplasma capsulatum AMC_HC002 sob o número de acesso no GenBank KT275850.1 como grupo externo e para a análise do gene gp43 exon 2 loci, foi inserida a sequência de nucleotídeo de B1 - T1F1 como referência da variedade S1a de $P$. brasiliensis sensu stricto, sob o número de acesso no GenBank DQ003724.1 (HRYCYK et al., 2018).

\subsection{Análise dos dados epidemiológicos dos pacientes com isolamento fúngico de Paracoccidioides spp.}

Os prontuários médicos dos pacientes foram analisados para obter informações quanto à forma clínica da PCM e a procedência geográfica de cada indivíduo cujo Paracoccidioides spp. foi estudado genotipicamente. Os dados epidemiológicos, residência e a manifestação clínica do paciente, foram relacionados com os dados genotípicos dos isolados clínicos de Paracoccidioides spp. obtidos no estudo. 
Tabela 1. Primers específicos, tamanho dos produtos de PCR, temperaturas de anelamento e referências dos métodos utilizados para a caracterização molecular dos isolados clínicos e ambientais de Paracoccidioides spp..

\begin{tabular}{|c|c|c|c|c|c|}
\hline Genes & Primer & Sequência (5'->3') & $\begin{array}{c}\text { Temperatura } \\
\text { Anelamento } \\
\text { (ㄷ) }\end{array}$ & $\begin{array}{l}\text { Amplicon } \\
\text { (pb) }\end{array}$ & Referências \\
\hline \multirow[t]{2}{*}{ gp43 Exon 2 loci parcial } & $g p 43-E 2 F$ & CCA GGA GGC GTG CAG GTG TCC C & \multirow[t]{2}{*}{60} & \multirow[t]{2}{*}{533} & Cisalpino et al., 1996 \\
\hline & $g p 43-E 2 R$ & GCC CCC TCC GTC TTC CAT GTC C & & & \\
\hline tub1 & $\begin{array}{l}\text { tub1F } \\
\text { tub1R }\end{array}$ & $\begin{array}{l}\text { CTG GGA GGT ATG ATA ACA CTG C } \\
\text { CGT CGG GCT ATT CAG ATT TAA G }\end{array}$ & 60 & 263 & $\begin{array}{l}\text { Kasuga et al., } 2002 \\
\text { Roberto et al., } 2016\end{array}$ \\
\hline gp43 Exon 2 loci & $\begin{array}{l}P b \_g p 43-E 2 F \\
P b \_g p 43-E 2 R\end{array}$ & $\begin{array}{l}\text { CTA GAA TAT CTC ACT CCC AG } \\
\text { GCC CCC TCC GTC TTC CAT GTC C }\end{array}$ & 58 & 722 & $\begin{array}{l}\text { Matute et al., } 2006 \\
\text { Hrycyk et al., } 2018\end{array}$ \\
\hline ITS1-5.8S-ITS2 rDNA & $\begin{array}{l}\text { ITS } 1 \\
\text { ITS } 4\end{array}$ & $\begin{array}{l}\text { TCC GTA GGT GAA CCT GCG G } \\
\text { TCC TCC GCT TAT TGA TAT GC }\end{array}$ & 65 & 633 & $\begin{array}{l}\text { White et al., } 1990 \\
\text { Hrycyk et al., } 2018\end{array}$ \\
\hline
\end{tabular}

Autoria: Fonte Própria. 


\subsection{Avaliação da antigenicidade de isolados de Paracoccidioides spp.}

\subsubsection{Produção de exoantigenos da fase micelial de cepas de referência e clínicas de Paracoccidioides spp.}

Para maior compreensão da atividade antigênica de diferentes antígenos produzidos por espécies do complexo $P$. brasiliensis e $P$. lutzii, as cepas Pb18, HCRP180 e HCRP171, representantes da espécie $P$. brasiliensis sensu stricto (S1b e S1a); Pbdog - EPM 194 e HCRP199, representantes da espécie $P$. americana (PS2); T2 - EPM 54, representante da espécie $P$. restrepiensis (PS3) e Pb01 e HCRP191 representantes da espécie $P$. lutzii foram cultivadas para produzir exoantígenos na fase micelial do fungo.

Cada cepa representante das espécies e variantes do gênero Paracoccidioides spp. foi crescida em tubos de vidro (tubos de ensaio) contendo o meio de cultura Fava - Neto (FAVA - NETO et al., 1955) a $35^{\circ} \mathrm{C}$ por um período de 7 dias de crescimento. Após este período, os inóculos foram preparados a partir da coleta das células leveduriformes e adicionada uma solução de $2 \mathrm{~mL}$ de salina $0,9 \%$, em um tubo cônico estéril de $15 \mathrm{~mL}$ (Corning ${ }^{\circledR}$, Tewksbury, MA, Estados Unidos). As suspensões contendo as leveduras de cada espécies de Paracoccidioides spp. foram submetidas a um processo de liberação das microcolônias de fungos por passagens repetidas em uma seringa de $10 \mathrm{~mL}$ de vidro estéril e agulha hipodérmica de calibre $21 \mathrm{G} 1^{1 / 2}$ (BD PrecisionGlide ${ }^{\circledR}$, Curitiba, PR, Brasil). Após esta etapa, as células foram transferidas para um tubo cônico estéril de $50 \mathrm{~mL}$ (Corning ${ }^{\circledR}$, Tewksbury, MA, Estados Unidos) onde, o filtro Falcon ${ }^{\circledR}$ Cell Strainer $40 \mu \mathrm{m}$ Nylon (Corning ${ }^{\circledR}$, Tewksbury, MA, Estados Unidos) foi acoplado com objetivo de reter impurezas na suspensão celular. As células leveduriformes foram contadas em uma câmera de Neubauer e o inóculo ajustado para $2 \times 10^{6}$ por $\mathrm{mL}$. A viabilidade celular 
das cepas de referência e clínicas de Paracoccidioides spp. foi verificada com a adição de uma solução $0,4 \%$ de azul de Trypan (Thermo Fisher Scientifc Inc ${ }^{\circledR}$, Waltham, MA, Estados Unidos) e observada em microscópio juntamente com a etapa da contagem das células, conforme descrito por Camargo et al. (2003).

A produção de exoantígenos foi realizada de duas maneiras: (i) volume de $250 \mu \mathrm{L}$ na concentração de $5 \times 10^{5}$ células de cada isolado de referência e clínico do complexo $P$. brasiliensis e da espécie $P$. lutzii, foi inoculado em cada um de quatro (4) tubos cônicos de $50 \mathrm{~mL}$ (Corning ${ }^{\circledR}$, Tewksbury, MA, Estados Unidos) contendo 25 $\mathrm{mL}$ de meio de cultura liquido sintético e modificado McVeigh e Morton (McM) e incubados por 30 e 60 dias, respectivamente, em uma temperatura constante a $25^{\circ} \mathrm{C}$ em um agitador orbital (Infors HT - Ecotron ${ }^{\circledR}$, Bottmingen, Suíça) a 130 rpm; (ii) 1 $\mathrm{mL}$ na concentração de $2 \times 10^{6}$ células de cada cepa de referência e clínica foi inoculada em $100 \mathrm{~mL}$ de meio de cultura liquido McVeigh e Morton (McM) em um Erlenmeyer de $250 \mathrm{~mL}$ e incubados a temperatura ambiente por 30 e 60 dias, respectivamente, na forma de crescimento estático (sem agitação). Antes do processo de coleta do exoantígenos, foi observado em ambos os métodos se houve uma possível contaminação, se confirmado o frasco contendo o inóculo era excluído do experimento.

Após o período de crescimento, para ambos os métodos de produção de exoantígenos o meio de cultura e o micélio formado durante o desenvolvimento fúngico foram submetidos a um processo de filtragem utilizando o Falcon ${ }^{\circledR}$ Cell Strainer $40 \mu \mathrm{m}$ Nylon (Corning ${ }^{\circledR}$, Tewksbury, MA, Estados Unidos) para a separação de ambos. O meio de cultura coletado foi submetido a diálise utilizando Dialysis sacks de $35 \mathrm{~mm}$ para retenção de proteínas acima de 12 kDa (Sigma Aldrich ${ }^{\circledR}$, Inc. St. Louis, MO, Estados Unidos). Este procedimento foi realizado por uma etapa de 
troca osmótica com solução de PBS $1 x$ estéril à $4^{\circ} \mathrm{C}$, sendo e realizadas quatro (4) trocas do tampão no período de 24 horas. Após a diálise, o volume $(\mathrm{mL})$ do líquido no interior dos sacos de diálise foi concentrado para $10 \%$ do seu volume, processo este realizado na temperatura de $4^{\circ} \mathrm{C}$ em tempo de até 96 horas. $\mathrm{O}$ volume final (aproximadamente $10 \mathrm{~mL}$ ) dos exoantígenos miceliais foi coletado dos sacos de diálise e armazenado em frascos âmbar estéreis e congelados a $-20^{\circ} \mathrm{C}$.

O exoantígeno micelial de HCRPBAT utilizado neste estudo, foi obtido pelo método de crescimento estacionário e incubando fragmentos de micélio em meio de cultura liquido sintético e modificado McVeigh e Morton (McM) à temperatura ambiente por 60 dias. Este exoantígeno foi produzido no ano de 1989 e armazenado $\mathrm{a}-20^{\circ} \mathrm{C}$

\subsubsection{Critério de seleção de exoantígenos miceliais de Paracoccidioides spp. para utilização nos testes de antigenicidade}

Os exoantígenos miceliais, produzidos a partir das cepas de referência e clínicas de cada espécie representantes do complexo $P$. brasiliensis e de $P$. lutzii, foram previamente testados quanto a sua reatividade antigênica frente a soros controle positivos de PCM utilizando a técnica de imunodifusão dupla (IDD). Os exoantígenos de cada espécie e cepa com maior reatividade frente ao pool de soros foram selecionados para a realização dos testes sorológicos utilizando as técnicas de IDD e CIE.

Estes exoantígenos selecionados também foram submetidos a uma avaliação de perfil proteico pelo método de eletroforese SDS - PAGE e também tiveram determinada a concentração proteica pelo método de Bradford, métodos descritos por Camargo et al. (2003). 


\subsubsection{Precipitação de proteínas a partir das frações miceliais produzidos pelas} cepas de referência e clínica das espécies do complexo $P$. brasiliensis e de $P$. lutzii

As proteínas foram precipitadas a partir das soluções de exoantígenos miceliais produzidos pelas cepas de referência e clínica das espécies do complexo P. brasiliensis e de P. lutzii, conforme descrito por Cocio et al. (2016), com modificações: $5 \mathrm{~mL}$ da solução contendo as proteínas extracelulares (exoantigenos) de cada cepa de referência e clínica foram filtrados em Falcon ${ }^{\circledR}$ Cell Strainer $40 \mu \mathrm{m}$ Nylon (Corning ${ }^{\circledR}$, Tewksbury, MA, Estados Unidos) e em seguida adicionado 6X o volume de acetona (LS Chemicals ${ }^{\circledR}$, Ribeirão Preto, SP, Brasil), previamente refrigerada a $-20 \stackrel{\circ}{\mathrm{C}}$ por 24 horas. Após, a solução de acetona com exoantígenos foi centrifugada a $4000 \mathrm{rpm}$ a $4^{\circ} \mathrm{C}$ durante 60 minutos (Eppendorf ${ }^{\oplus}$, Hamburgo, Alemanha). As proteínas extracelulares sedimentadas foram ressuspendidas em 100 $\mu \mathrm{L}$ em água ultra pura estéril (Millipore ${ }^{\circledR}$, Burlington, MA, EUA) para determinação da concentração de proteína pelo método de Bradford e avaliar perfil e integridade proteica em gel de eletroforese SDS-PAGE.

\subsubsection{Determinação da concentração de proteínas precipitadas a partir das frações miceliais produzidos das cepas de referência e clínica}

A concentração de proteínas precipitadas a partir das soluções contendo produtos liberados em caldo de cultura pelas cepas de referência e clínica de cada espécie do gênero Paracoccidioides spp. foi determinada pelo método de Bradford (1976). O reagente Protein Assay Dye Reagent Concentrate (Bradford) (Bio - Rad®, Hercules, CA, Estados Unidos) foi preparado em uma concentração 1:5 sendo, 1mL do reagente e $4 \mathrm{~mL}$ de água ultra pura estéril (Millipore ${ }^{\circledR}$, Burlington, MA, EUA). A 
curva padrão foi determinada utilizando Soro Albumina Bovina (Sigma Aldrich ${ }^{\circledR}$, Inc. St. Louis, MO, Estados Unidos) usando as concentrações de 2,0 mg/mL, 1,5 mg/mL, $1,0 \mathrm{mg} / \mathrm{mL}, 0,75 \mathrm{mg} / \mathrm{mL}, 0,5 \mathrm{mg} / \mathrm{mL}, 0,25 \mathrm{mg} / \mathrm{mL}, 0,125 \mathrm{mg} / \mathrm{mL}$ e $0,025 \mathrm{mg} / \mathrm{mL}$.

Foram adicionados $180 \mu \mathrm{L}$ do reagente de Bradford e $20 \mu \mathrm{L}$ das soluções de curva padrão (Albumina), $20 \mu \mathrm{L}$ das amostras e $20 \mu \mathrm{L}$ água ultra pura estéril (Branco) em uma placa para cultivo de células de 96 poços fundo chato (Kasvi ${ }^{\circledR}$, Pinhais, PR, Brasil) em um volume final de $200 \mu \mathrm{L}$, em duplicata. A absorbância de cada amostra contendo exoantígenos foi obtida utilizando um leitor de microplacas de absorbância iMARK $^{\text {TM }}$ (Bio - Rad®, Hercules, CA, Estados Unidos) no comprimento de onda de $595 \mathrm{~nm}$, leitura realizada em duplicata. A concentração proteica de cada cepa avaliada neste estudo foi determinada através de um cálculo correlacionando valores de absorbância da curva padrão $\left(\mathrm{r}^{2}\right)$ com as das suspensões antigênicas, em duplicata, e calculada uma média dos valores das massas em $\mu \mathrm{g} / \mathrm{mL}$.

\subsubsection{Verificação de perfil proteico de exoantígenos miceliais de espécies do gênero Paracoccidioides spp.}

Para verificar e avaliar o perfil proteico de cada amostra contendo exoantígenos de espécies do gênero Paracoccidioides spp., foi aplicado $50 \mu \mathrm{g}$ de proteína da amostra em gel 10\% SDS (policrilamida - dodecil - sulfato de sódio), utilizando-se sistema de eletroforese Mini PROTEAN ${ }^{\circledR} 3$ Cell (Bio - Rad ${ }^{\circledR}$, Hercules, CA, Estados Unidos), conforme método descrito por Sambrook \& Russel (2001). Foi adicionado o marcador de peso molecular Precision Plus Protein ${ }^{T M}$ Kaleidoscope ${ }^{\mathrm{TM}}$ Standards (Bio - Rad ${ }^{\circledR}$, Hercules, CA, Estados Unidos) nos géis SDS produzidos para esta etapa. As amostras foram preparadas em um tampão onde foi adicionado 
$\beta$ - mercaptoetanol para o fracionamento em SDS-PAGE. A corrida eletroforética foi realizada com uma corrente elétrica de $100 \mathrm{~V}$ por 80 minutos, utilizando-se tampão de corrida (Tris - HCL $25 \mathrm{mM}$, Glicina $19 \mathrm{mM}$, SDS $0,1 \%(\mathrm{p} / \mathrm{v})$ ), todos produtos Sigma Aldrich ${ }^{\circledR}$.

Após a eletroforese, o gel SDS foi submetido a coloração por Nitrato de Prata $\left(\mathrm{AgNO}_{3}\right)$. O gel foi colocado em solução A (50\% de Metanol, 10\% de Ácido Acético e $40 \%$ de água ultra pura (v/v)) e incubado por uma (1) hora submetido a uma agitação orbital de aproximadamente 50 rpm (Fanem ${ }^{\circledR}$, Guarulhos, SP, Brasil). Após a incubação do gel, descartou-se a Solução A e adicionou-se a Solução B (95\% de água ultra e $5 \%$ de metanol $(\mathrm{v} / \mathrm{v}))$ por 15 minutos em agitação orbital a $50 \mathrm{rpm}$. Descartou-se a Solução B e lavou-se 5 vezes por 5 minutos cada com água ultra pura em agitação orbital a $50 \mathrm{rpm}$. Após as lavagens, foi adicionada a Solução C $\left(0,1 \mathrm{~g}\right.$ de $\mathrm{Na}_{2} \mathrm{~S}_{2} \mathrm{O}_{3}$ em $500 \mathrm{~mL}$ de água ultra pura $\left.(\mathrm{p} / \mathrm{v})\right)$ por 2 minutos e reservandose $10 \mathrm{~mL}$ para ser adicionado na Solução E. Realizou-se então lavagens com água ultra pura por 3 vezes por 30 segundos cada. Foi adicionada a Solução D $(0,8 \mathrm{~g}$ de $\mathrm{AgNO}_{3}$ solubilizado em $400 \mathrm{~mL}$ de água ultra pura $\left.(\mathrm{p} / \mathrm{v})\right)$ e incubando-se por 10 minutos em agitação orbital de aproximadamente 50 rpm. Lavou-se com água ultra pura por 3 vezes por 30 segundos cada. Foi adicionada a Solução $E(10 \mathrm{~mL}$ da Solução $\mathrm{C}, 30 \mathrm{~g}$ de $\mathrm{CaCO}_{3}, 500 \mu \mathrm{L}$ de formaldeído $37 \%$ e completado para um (1) litro de água ultra pura $(\mathrm{p} / \mathrm{v}))$. Incubou-se com $150 \mathrm{~mL}$ da Solução $\mathrm{E}$ por 30 segundos ou até se observar que o líquido ficou com a coloração "marrom". Descartou-se o líquido e adicionou-se mais Solução E, observando a reação por aproximadamente de 60 a 120 segundos, controlando o tempo para não aumentar o "background" do gel. Bloqueou-se a reação química da Solução E adicionando 
Solução $\mathrm{F}$ (7g de EDTA em $500 \mathrm{~mL}$ de água ultra pura) e incubou-se por 10 minutos. Após, foi realizada uma única lavagem com água ultra pura.

Depois do processo de coloração com $\mathrm{AgNO}_{3}$, foi fotodocumentado o gel e selando com plástico para mantê-lo em boas condições.

\subsubsection{Verificação de antigenicidade das frações miceliais de espécies do gênero Paracoccidioides spp. frente a soros de pacientes com PCM}

\subsubsection{Soros de pacientes com PCM utilizados nos testes sorológicos}

Para a antigenicidade das frações miceliais de espécies diferentes do gênero Paracoccidioides spp., foram utilizados soros de 15 pacientes com PCM dos quais Paracoccidioides spp. isolado em cultura foi genotípado conforme descrito anteriormente. Estes soros foram coletados no período de 1985 a 2019 e tinham anticorpos contra pool de antígenos de leveduras de Paracoccidioides spp. rompidas com ultrassom, cujo título obtido no laboratório de sorologia do HC - FMRP/USP é mostrado no Anexo 2 - Tabela Suplementar 2. Soros de outros pacientes cujo isolado de Paracoccidioides spp. foi genotípado não estavam disponíveis para a avaliação dos antígenos do fungo.

\subsubsection{Avaliação das amostras contendo exoantígenos miceliais de espécies} do gênero Paracoccidioides spp. utilizando a técnica de imunodifusão dupla (IDD)

O teste IDD foi realizado conforme método descrito por Bellissimo Rodrigues et al. (2010) onde placas de vidro com medida de $8 \times 10 \mathrm{~cm}$ foram recobertas com agarose do tipo II (Sigma Aldrich ${ }^{\circledR}$, Inc. - St. Louis, MO, Estados Unidos) diluída em um tampão TBE 1x, pH 8,0. Após solidificado, o gel foi e 
perfurado com molde metálico para formar um poço central e seis periféricos (Figura $5 A)$.

O orifício central foi preenchido com $80 \mu \mathrm{L}$ de soros dos pacientes e nos periféricos aplicados $80 \mu \mathrm{L}$ das amostras com exoantígenos miceliais de cada espécie do gênero Paracoccidioides spp. Um dos poços periféricos foi preenchido com controle positivo, representado por pool de antígenos oriundos do rompimento das células leveduriformes por sonicação, contendo as cepas Pb18 - P. brasiliensis sensu stricto (S1b), Pb339 - P. brasiliensis sensu stricto (S1b), BAT - P. restrepiensis (PS3), BOAS - P. brasiliensis sensu stricto (S1b).

Após a aplicação dos soros e exoantígenos, as placas foram incubadas por 72 horas em uma câmara montada em uma placa de petri de diâmetro 150x15 mm com algodões umedecidos estéreis. Depois, as placas foram imergidas em solução de Citrato de Sódio $5 \%$ por 1 hora e em seguida a salina 0,9\% por 24 horas. Após, o gel foi submetido à secagem em temperatura ambiente por 24 horas e em seguida corado com solução de Coomassie Brilliant Blue R - 250 (Sigma Aldrich ${ }^{\circledR}$, Inc. - St. Louis, MO, Estados Unidos). A formação de uma ou mais linhas de precipitação entre o poço do soro e dos exoantígenos foi considerada reação positiva e indicativa de antigenicidade da respectiva amostra.

\subsubsection{Avaliação das amostras contendo exoantígenos miceliais de espécies do gênero Paracoccidioides spp. utilizando a técnica de contraimunoeletroforese (CIE)}

A CIE foi realizada, conforme método descrito por Cocio et al. (2021) e Bellissimo - Rodrigues et al. (2010), com modificações, em placas de vidro de 8 x 10 cm cobertas com gel de agarose tipo II (Sigma Aldrich ${ }^{\circledR}$, Inc. - St. Louis, MO, Estados 
Unidos) diluído em tampão TBE 1x, pH 8,0. Duas filas paralelas de poços perfurados no gel receberam, respectivamente, $5 \mu \mathrm{L}$ do exoantígeno e $10 \mu \mathrm{L}$ o soro do paciente a ser testado (Figura 5B).

A fim de que ocorresse a reação antigênica, a placa foi colocada em cuba de eletroforese, e submetida a uma corrente elétrica por 60 minutos a $15 \mathrm{~mA}$ (miliampéreres), com o antígeno mais próximo do pólo negativo. Após, as placas foram imergidas em solução de Citrato de Sódio 5\% por 1 hora e em seguida a salina $0,9 \%$ por 24 horas. Após, o gel foi submetido a secagem em temperatura ambiente por 24 horas e em seguida corado com Coomassie Brilliant Blue R - 250 (Sigma Aldrich ${ }^{\circledR}$, Inc. - St. Louis, MO, Estados Unidos). 
A.

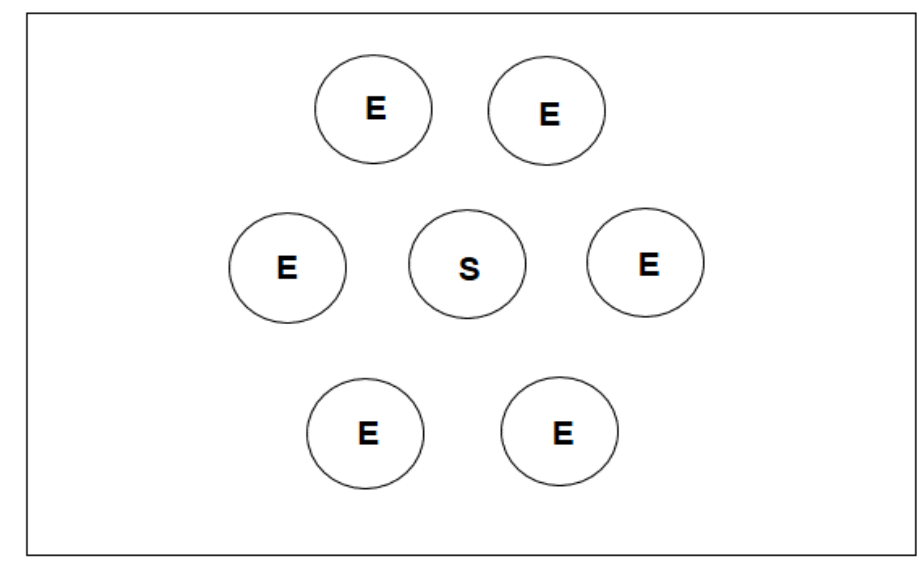

B.

\begin{tabular}{|cccccccccc|}
\hline 0 & 0 & 0 & 0 & 0 & 0 & 0 & 0 & 0 & Exoantigenos \\
0 & 0 & 0 & 0 & 0 & 0 & 0 & 0 & 0 & Soros \\
0 & 0 & 0 & 0 & 0 & 0 & 0 & 0 & 0 Exoantigenos \\
0 & 0 & 0 & 0 & 0 & 0 & 0 & 0 & 0 & Soros \\
\hline
\end{tabular}

Figura 5: Representação esquemática das placas dos testes sorológicos utilizados neste trabalho. A. Técnica de imunodifusão dupla (IDD) - S: soro do paciente e E: Exoantígenos. B. Técnica de contraímunoeletroforese (CIE). Autoria: Fonte Própria. 


\subsection{Estatística}

Foi usada estatística descritiva simples para os resultados de reatividade de exoantígenos e na comparação entre genótipos e formas clínicas de PCM.

\section{6. Ética}

O estudo foi aprovado pelo Comitê de Ética em Pesquisa do Hospital das Clínicas da Ribeirão Preto, da Faculdade de Medicina de Ribeirão Preto FMRP/USP Universidade de São Paulo (Protocolo HCRP no 4456/2017) (Anexo 3). 
5. RESULTADOS 


\section{RESULTADOS}

5.1. Caracterização molecular dos isolados clínicos e ambientais de Paracoccidioides spp.

\subsubsection{Verificação molecular do gênero Paracoccidioides spp.}

O DNA genômico dos isolados clinicos, ambientais e cepas de referências avaliados neste estudo foram submetidos a PCR convencional para amplificar parcialmente o gene gp43 exon 2 loci, o qual confirmou que todas as amostras fúngicas pertencem ao gênero Paracoccidioides spp. (Figura 6).


Figura 6: Amplificação parcial do gene gp43 exon 2 loci por PCR convencional das cepas de referência (Pb18: $P$. brasiliensis sensu stricto (S1b); Pbdog - EPM 194: $P$. americana (PS2); T2 - EPM 54: P. restrepiensis (PS3); Pb_01: P. lutzii.) e dos isolados clínicos (001 a 200, FOZ_1, FOZ_2, BAT, BOAS e TONI) e ambientais (IBIÁ, IBIÁT1, IBIÁT2 e IBIÁT3) de avaliados neste estudo para confirmação do 
gênero Paracoccidioides spp., conforme verificado em gel de agarose 2\%. M: 100 bp Ladder, Ready-To-Use (Sinapse ${ }^{\circledR}$ Inc, Estados Unidos) e CN: controle negativo. Autoria: Fonte Própria.

\subsubsection{Identificação das espécies dos isolados clínicos e ambientais de Paracoccidioides spp. pela técnica PCR - RFLP do gene tub1}

Os isolados clínicos e ambientais, já confirmados como pertencentes ao gênero Paracoccidioides spp., foram submetidos à técnica de PCR - RFLP do gene tub1, sendo observada amplificação do produto da PCR no tamanho aproximado de 263 pb (Figura 7). Dos 49 isolados submetidos a técnica RFLP, 43 isolados clínicos e 4 ambientais foram identificados como pertencentes a $P$. brasiliensis sensu stricto (S1), onde a enzima Bcll reconheceu o sitio de restrição gerando dois (2) fragmentos, um (1) de 155 pb e um (1) de 108 pb (Figura 8). Para o isolado HCRP199, ambas as enzimas reconheceram 2 (dois) sítios de restrições distintos gerando 3 (três) fragmentos, um (1) de 62 pb, um (1) de 93 pb e um (1) de 108 pb, o classificando como P. americana (PS2) (Figura 8). O isolado HCRPBAT foi identificado como $P$. restrepiensis (PS3), não possuindo sitio de clivagem para as endonucleases Bcll e Mspl, portanto foi observado que o gene tub1 do isolado clínico analisado neste estudo manteve sua total integridade (263 pb) (Figura 8 e Tabela 2).

Somente para o isolado HCRP191 não ocorreu à amplificação do gene tub1, assim excluído da técnica PCR - RFLP e submetido ao sequenciamento da região ITS1-5.8S-ITS2 rDNA para verificar a qual espécie pertence - se, do complexo $P$. brasiliensis ou P. lutzii (Figura 7). 

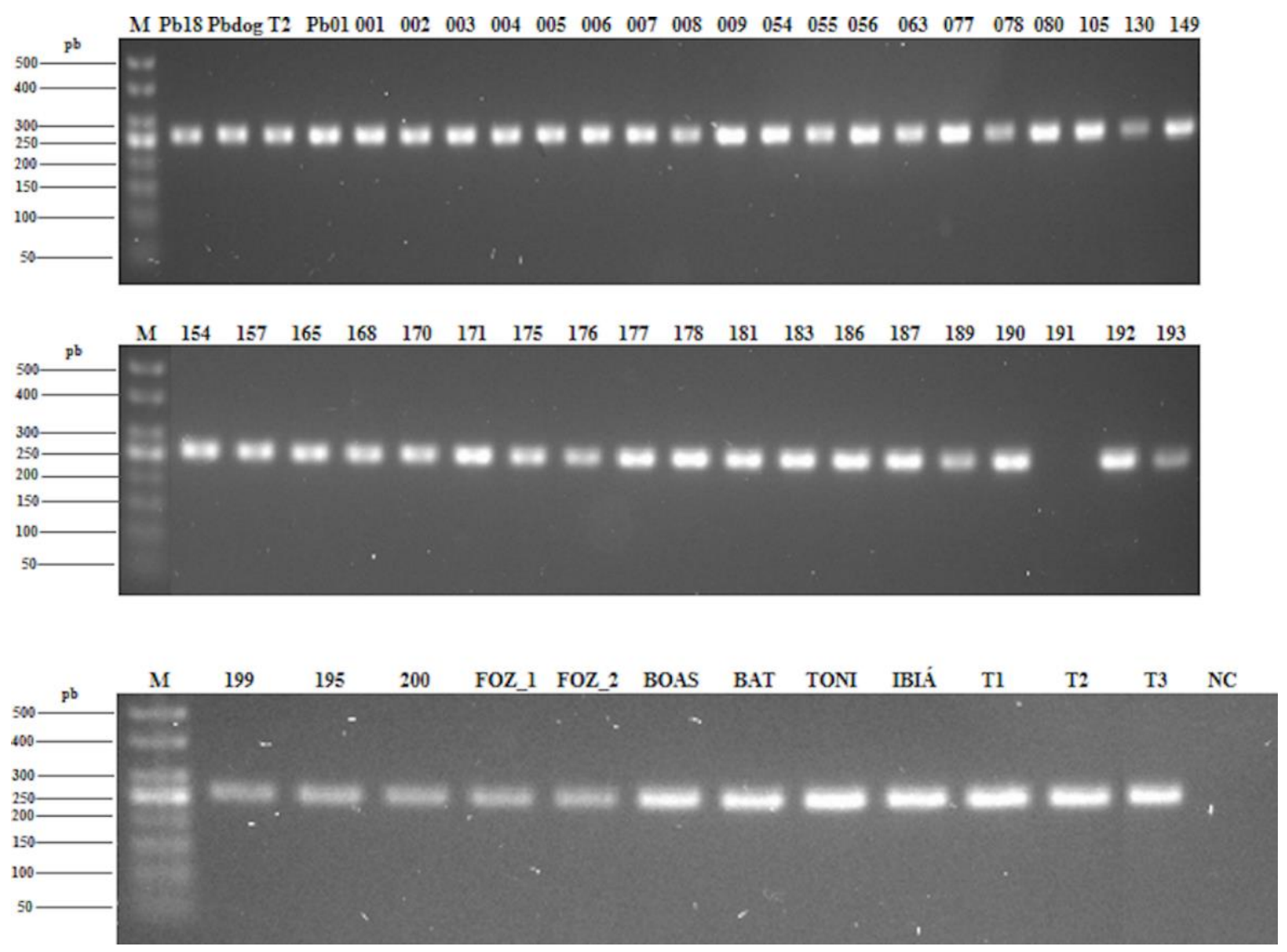

Figura 7: Amplificação do gene tub1 para realização da técnica PCR-RFLP nas cepas de referência (Pb18: P. brasiliensis sensu stricto (S1b); Pbdog - EPM 194: $P$. americana (PS2); T2 - EPM 54: P. restrepiensis (PS3); Pb_01: P. lutzii.) e dos isolados clínicos (001 a 200, FOZ_1, FOZ_2, BAT, BOAS e TONI) e ambientais (IBIÁ, IBIÁT1, IBIÁT2 e IBIÁT3) de Paracoccidioides spp. avaliados neste estudo. Todos os isolados tiveram o gene tub1 amplificado, exceto o isolado HCRP191. M: marcador de peso molecular de 50 bp DNA ladder (Sinapse $\AA^{\circledR}$ Inc, Estados Unidos) e NC: controle negativo. Autoria: Fonte Própria; Publicado na revista Journal of Fungi em 07/08/2020 - Cocio et al., 2020. 


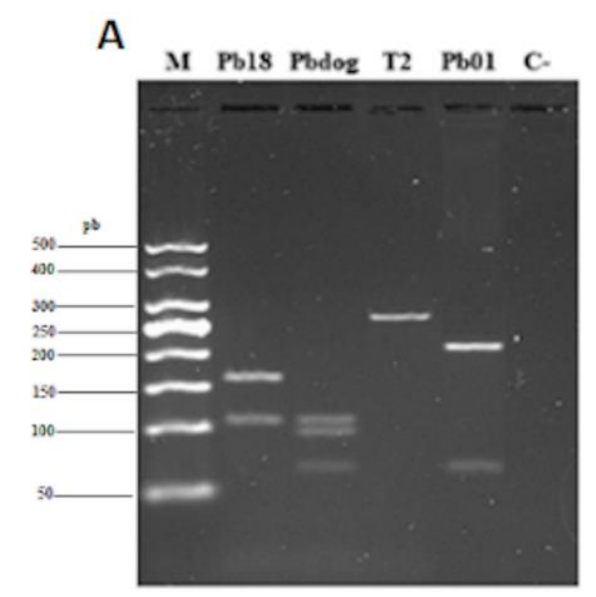

B


Figura 8: Padrões de fragmentos obtidos após a digestão com as endonucleases Bcll e Mspl, mostrando similaridade dos isolados clínicos e ambientais com as cepas de referência. (A) Gel de Agarose 3\% com as cepas de referências Pb18: $P$. brasiliensis sensu stricto (S1b); Pbdog - EPM 194: P. americana (PS2); T2 - EPM 54: P. restrepiensis (PS3); Pb_01: P. lutzii. (B) Gel de Agarose 3\% com isolados clínicos (001 a 200, FOZ_1, FOZ_2, BAT, BOAS e TONI) e ambientais (IBIÁ, IBIÁT1, 
IBIÁT2 e IBIÁT3) de Paracoccidioides spp. caracterizados neste estudo. A maioria dos isolados mostrou padrão de digestão enzimática compatível com $P$. brasiliensis sensu stricto (S1), mas os isolados HCRP199 e HCRPBAT tiveram padrão similar, respectivamente, $P$. americana (PS2) e $P$. restrepiensis (PS3). M: marcador de peso molecular de 50 bp DNA ladder (Sinapse® Inc, Estados Unidos) e NC: Negative Control. Autoria: Fonte Própria; Publicado na revista Journal of Fungi em 07/08/2020 - Cocio et al., 2020.

\subsubsection{Sequenciamento da região ITS1-5.8S-ITS2 rDNA para identificação de espécies do complexo $\boldsymbol{P}$. brasiliensis e de $\boldsymbol{P}$. Iutzii}

Devido a não identificação molecular do isolado HCRP191 pela técnica PCR RFLP do gene tub1, foi necessário realizar o sequenciamento da região ITS1-5.8SITS2 rDNA para classificá-lo em espécie do complexo $P$. brasiliensis e ou como $P$. lutzii.

A cepa HCRP191 apresentou 99,50\% de similaridade com a sequência de nucleotídeos ITS de Pb01 ( $P$. lutzii) (EU870297.1), assim o identificando como pertencente a esta espécie. Foi observado na análise filogenética de máxima verossimilhança $(\mathrm{ML})$ adotando o modelo evolutivo Tamura - Nei que existe um distanciamento evolutivo de HCRP191 frente as espécies pertencentes ao complexo P. brasiliensis e H. capsulatum AMC HCO02 (Tabela 2 e Figura 9).

A sequência de ITS1-5.8S-ITS2 de HCRP191 foi depositada no GenBank: https://www.ncbi.nlm.nih.gov/genbank/ sob o número de acesso MK886790. 


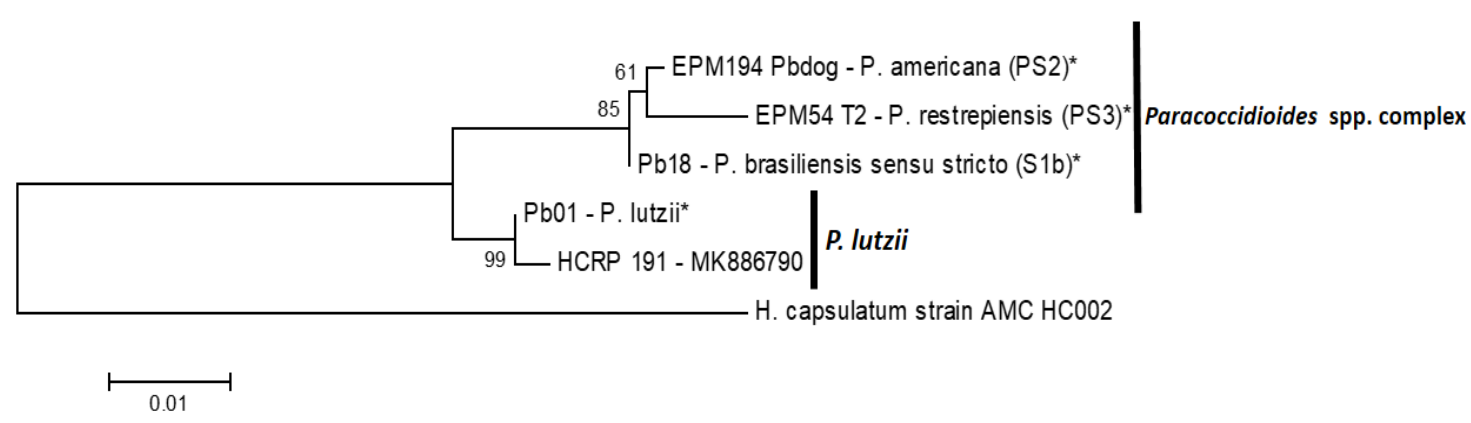

Figura 9: Análise filogenética da região ITS1-5.8S-ITS2 rDNA do isolado HCRP191 em comparação com as cepas de referência $\left(^{\star}\right)$; estas também foram sequenciadas para este estudo e tinham $100 \%$ de identidade com as sequências depositadas no GenBank sob o número de acesso: [Pb18 - B17 ( $P$. brasiliensis sensu stricto (S1b)), EPM194 - Pbdog- (P. americana (PS2)) e EPM54 - T2 (P. restrepiensis (PS3)) - KT155977.1 para três cepas de referência; Pb01 — EU870297.1 (P. lutzii)] e H. capsulatum AMC_HCO02 são um grupo externo. A história evolutiva foi medida pelo método de máxima verossimilhança $(\mathrm{ML})$ baseado no modelo de Tamura-Nei. A alta similaridade com Pb01 identifica HCRP 191 como P. lutzii. Autoria: Fonte Própria; Publicado na revista Journal of Fungi em 07/08/2020 - Cocio et al., 2020.

\subsubsection{Análise filogenética utilizando o sequenciamento do gene gp43 exon 2 loci para identificação de espécies e variedades do complexo $P$. brasiliensis e P. Iutzii}

Pela análise de nucleotídeos de gp43 exon 2 loci obtidas no sequenciamento, 47 cepas foram identificadas como $P$. brasiliensis sensu stricto (S1), sendo 5 isolados pertencentes a variedade S1a com 100\% de similaridade a DQ003724.1 B1 - T1F1 (S1a) e 42 isolados pertencentes a variedade S1b com 100\% de similaridade a DQ003729.1 B17 - Pb18. O isolado HCRP191 foi identificado como pertencente a espécie P. lutzii, apresentando 100\% de similaridade à sequência de EU870196.1 
Pb01 (P. lutzii). O isolado HCRP199 caracterizado como P. americana (PS2), apresentou 100\% de similaridade a sequência de nucleotídeos de gp43 exon 2 loci da cepa EPM194 - Pbdog - DQ003736.1. O isolado HCRPBAT foi identificado como pertencente à espécie $P$. restrepiensis (PS3), mostrando 100\% de similaridade com a cepa referência KT251008.1-T2-EPM54 (Tabela 2 e Figura 10).

As sequências de gp43 exon 2 loci dos isolados clínicos e ambientais foram depositadas no GenBank: https://www.ncbi.nlm.nih.gov/genbank/ sob o número de acesso MK909758 a MK909806 e para o isolado HCRPBAT o número de acesso é MH484614 (Tabela 2). 
Tabela 2. Caracterização genotípica dos isolados clinicos de Paracoccidioides spp.: Método de identificação e código de acesso

GenBank.

\begin{tabular}{|c|c|c|c|}
\hline \multirow[b]{2}{*}{ Isolado } & \multicolumn{2}{|c|}{ Método de identificação } & \multirow[b]{2}{*}{ GenBank } \\
\hline & $\begin{array}{c}\text { PCR-RFLP } \\
\text { tub1 }\end{array}$ & Sequenciamento gp43 exon 2 & \\
\hline HCRP 001 & P. brasiliensis sensu stricto $\mathrm{S} 1$ & P. brasiliensis sensu stricto S1b & MK909758 \\
\hline HCRP 002 & P. brasiliensis sensu stricto $\mathrm{S} 1$ & P. brasiliensis sensu stricto $\mathrm{S} 1 \mathrm{~b}$ & MK909759 \\
\hline HCRP 003 & P. brasiliensis sensu stricto $\mathrm{S} 1$ & P. brasiliensis sensu stricto $\mathrm{S} 1 \mathrm{~b}$ & MK909760 \\
\hline HCRP 004 & P. brasiliensis sensu stricto $\mathrm{S} 1$ & P. brasiliensis sensu stricto $\mathrm{S} 1 \mathrm{~b}$ & MK909761 \\
\hline HCRP 005 & P. brasiliensis sensu stricto $\mathrm{S} 1$ & P. brasiliensis sensu stricto $\mathrm{S} 1 \mathrm{~b}$ & MK909762 \\
\hline HCRP 006 & P. brasiliensis sensu stricto $\mathrm{S} 1$ & P. brasiliensis sensu stricto S1b & MK909763 \\
\hline HCRP 007 & P. brasiliensis sensu stricto $\mathrm{S} 1$ & P. brasiliensis sensu stricto $\mathrm{S} 1 \mathrm{~b}$ & MK909764 \\
\hline HCRP 008 & P. brasiliensis sensu stricto $\mathrm{S} 1$ & P. brasiliensis sensu stricto $\mathrm{S} 1 \mathrm{~b}$ & MK909765 \\
\hline HCRP 009 & P. brasiliensis sensu stricto $\mathrm{S} 1$ & P. brasiliensis sensu stricto $\mathrm{S} 1 \mathrm{~b}$ & MK909766 \\
\hline HCRP 054 & P. brasiliensis sensu stricto $\mathrm{S} 1$ & P. brasiliensis sensu stricto S1a & MK909767 \\
\hline HCRP 055 & P. brasiliensis sensu stricto $\mathrm{S} 1$ & P. brasiliensis sensu stricto $\mathrm{S} 1 \mathrm{~b}$ & MK909768 \\
\hline HCRP 056 & P. brasiliensis sensu stricto $\mathrm{S} 1$ & P. brasiliensis sensu stricto $\mathrm{S} 1 \mathrm{~b}$ & MK909769 \\
\hline HCRP 063 & P. brasiliensis sensu stricto $\mathrm{S} 1$ & P. brasiliensis sensu stricto $\mathrm{S} 1 \mathrm{~b}$ & MK909770 \\
\hline HCRP 077 & P. brasiliensis sensu stricto $\mathrm{S} 1$ & P. brasiliensis sensu stricto $\mathrm{S} 1 \mathrm{~b}$ & MK909771 \\
\hline HCRP 078 & P. brasiliensis sensu stricto $\mathrm{S} 1$ & P. brasiliensis sensu stricto $\mathrm{S} 1 \mathrm{~b}$ & MK909772 \\
\hline HCRP 080 & P. brasiliensis sensu stricto $\mathrm{S} 1$ & P. brasiliensis sensu stricto $\mathrm{S} 1 \mathrm{a}$ & MK909773 \\
\hline HCRP 105 & P. brasiliensis sensu stricto $\mathrm{S} 1$ & P. brasiliensis sensu stricto $\mathrm{S} 1 \mathrm{~b}$ & MK909774 \\
\hline HCRP 130 & P. brasiliensis sensu stricto $\mathrm{S} 1$ & P. brasiliensis sensu stricto $\mathrm{S} 1 \mathrm{~b}$ & MK909775 \\
\hline HCRP 149 & P. brasiliensis sensu stricto $\mathrm{S} 1$ & P. brasiliensis sensu stricto $\mathrm{S} 1 \mathrm{a}$ & MK909776 \\
\hline HCRP 154 & P. brasiliensis sensu stricto $\mathrm{S} 1$ & P. brasiliensis sensu stricto $\mathrm{S} 1 \mathrm{~b}$ & MK909777 \\
\hline
\end{tabular}

Autoria: Fonte Própria. 
Tabela 2. Caracterização genotípica dos isolados clinicos de Paracoccidioides spp.: Método de identificação e código de acesso GenBank (Continuação).

\section{Método de identificação}

\begin{tabular}{|c|c|c|c|}
\hline Isolado & $\begin{array}{c}\text { PCR-RFLP } \\
\text { tub1 }\end{array}$ & Sequenciamento gp43 exon 2 & GenBank \\
\hline HCRP 157 & P. brasiliensis sensu stricto $\mathrm{S} 1$ & P. brasiliensis sensu stricto $\mathrm{S} 1 \mathrm{~b}$ & MK909778 \\
\hline HCRP 165 & P. brasiliensis sensu stricto $\mathrm{S} 1$ & P. brasiliensis sensu stricto $\mathrm{S} 1 \mathrm{~b}$ & MK909779 \\
\hline HCRP 168 & P. brasiliensis sensu stricto $\mathrm{S} 1$ & P. brasiliensis sensu stricto $\mathrm{S} 1 \mathrm{~b}$ & MK909780 \\
\hline HCRP 170 & P. brasiliensis sensu stricto $\mathrm{S} 1$ & P. brasiliensis sensu stricto $\mathrm{S} 1 \mathrm{~b}$ & MK909781 \\
\hline HCRP 171 & P. brasiliensis sensu stricto $\mathrm{S} 1$ & P. brasiliensis sensu stricto $\mathrm{S} 1 \mathrm{a}$ & MK909782 \\
\hline HCRP 175 & P. brasiliensis sensu stricto $\mathrm{S} 1$ & P. brasiliensis sensu stricto $\mathrm{S} 1 \mathrm{~b}$ & MK909783 \\
\hline HCRP 176 & P. brasiliensis sensu stricto $\mathrm{S} 1$ & P. brasiliensis sensu stricto $\mathrm{S} 1 \mathrm{~b}$ & MK909784 \\
\hline HCRP 177 & P. brasiliensis sensu stricto $\mathrm{S} 1$ & P. brasiliensis sensu stricto $\mathrm{S} 1 \mathrm{~b}$ & MK909785 \\
\hline HCRP 178 & P. brasiliensis sensu stricto $\mathrm{S} 1$ & P. brasiliensis sensu stricto $\mathrm{S} 1 \mathrm{~b}$ & MK909786 \\
\hline HCRP 181 & P. brasiliensis sensu stricto $\mathrm{S} 1$ & P. brasiliensis sensu stricto $\mathrm{S} 1 \mathrm{~b}$ & MK909787 \\
\hline HCRP 183 & P. brasiliensis sensu stricto $\mathrm{S} 1$ & P. brasiliensis sensu stricto $\mathrm{S} 1 \mathrm{~b}$ & MK909788 \\
\hline HCRP 186 & P. brasiliensis sensu stricto $\mathrm{S} 1$ & P. brasiliensis sensu stricto $\mathrm{S} 1 \mathrm{~b}$ & MK909789 \\
\hline HCRP 187 & P. brasiliensis sensu stricto $\mathrm{S} 1$ & P. brasiliensis sensu stricto $\mathrm{S} 1 \mathrm{~b}$ & MK909790 \\
\hline HCRP 189 & P. brasiliensis sensu stricto $\mathrm{S} 1$ & P. brasiliensis sensu stricto $\mathrm{S} 1 \mathrm{~b}$ & MK909791 \\
\hline HCRP 190 & P. brasiliensis sensu stricto $\mathrm{S} 1$ & P. brasiliensis sensu stricto $\mathrm{S} 1 \mathrm{~b}$ & MK909792 \\
\hline *HCRP 191 & Não Identificado & P. lutzii & MK909806 MK886790 \\
\hline HCRP 192 & P. brasiliensis sensu stricto $\mathrm{S} 1$ & P. brasiliensis sensu stricto $\mathrm{S} 1 \mathrm{~b}$ & MK909793 \\
\hline HCRP 193 & P. brasiliensis sensu stricto $\mathrm{S} 1$ & P. brasiliensis sensu stricto $\mathrm{S} 1 \mathrm{a}$ & MK909794 \\
\hline HCRP 195 & P. brasiliensis sensu stricto $\mathrm{S} 1$ & P. brasiliensis sensu stricto $\mathrm{S} 1 \mathrm{~b}$ & MK909795 \\
\hline
\end{tabular}

Legenda: *HCRP191 não teve o gene tub1 amplificado e foi identificado pelo sequenciamento de gp43 Exon 2 loci e ITS1/ITS4 rDNA. Autoria: Fonte Própria. 
Tabela 2. Caracterização genotípica dos isolados clinicos de Paracoccidioides spp.: Método de identificação e código de acesso GenBank (Continuação).

\begin{tabular}{|c|c|c|c|}
\hline \multirow[b]{2}{*}{ Isolado } & \multicolumn{2}{|c|}{ Método de identificação } & \multirow[b]{2}{*}{ GenBank } \\
\hline & $\begin{array}{c}\text { PCR-RFLP } \\
\text { tub1 }\end{array}$ & Sequenciamento gp43 exon 2 & \\
\hline HCRP 199 & P. americana (PS2) & P. americana (PS2) & MK909796 \\
\hline HCRP 200 & P. brasiliensis sensu stricto $\mathrm{S} 1$ & P. brasiliensis sensu stricto $\mathrm{S} 1 \mathrm{~b}$ & MK909797 \\
\hline HCRP FOZ_1 & P. brasiliensis sensu stricto $\mathrm{S} 1$ & P. brasiliensis sensu stricto $\mathrm{S} 1 \mathrm{~b}$ & MK909798 \\
\hline HCRP FOZ_2 & P. brasiliensis sensu stricto $\mathrm{S} 1$ & P. brasiliensis sensu stricto $\mathrm{S} 1 \mathrm{~b}$ & MK909799 \\
\hline HCRP BAT & P. restrepiensis (PS3) & P. restrepiensis (PS3) & MH484614 \\
\hline HCRP BOAS & P. brasiliensis sensu stricto $\mathrm{S} 1$ & P. brasiliensis sensu stricto $\mathrm{S} 1 \mathrm{~b}$ & MK909800 \\
\hline HCRP TONI & P. brasiliensis sensu stricto $\mathrm{S} 1$ & P. brasiliensis sensu stricto $\mathrm{S} 1 \mathrm{~b}$ & MK909805 \\
\hline
\end{tabular}

Autoria: Fonte Própria.

Tabela 2A. Caracterização genotípica dos isolados ambientais de Paracoccidioides spp.: Método de identificação, código de acesso GenBank e Referências.

Método de identificação

\begin{tabular}{|c|c|c|c|c|c|c|c|}
\hline Isolado & Hospedeiro & Fonte & $\begin{array}{c}\text { Origem } \\
\text { geográfica }\end{array}$ & $\begin{array}{c}\text { PCR-RFLP } \\
\text { tub1 }\end{array}$ & Sequenciamento gp43 exon 2 & GenBank & Referências \\
\hline HCRPIBIA & Ambiente & Solo & Ibiá - MG & P. brasiliensis sensu stricto $\mathrm{S} 1$ & P. brasiliensis sensu stricto $\mathrm{S} 1 \mathrm{~b}$ & MK909801 & $\begin{array}{c}\text { Silva - Vergara et } \\
\text { al., } 1998\end{array}$ \\
\hline HCRPIBIAT1 & Tatu & Baço & Ibiá - MG & P. brasiliensis sensu stricto $\mathrm{S} 1$ & P. brasiliensis sensu stricto $\mathrm{S} 1 \mathrm{~b}$ & MK909802 & $\begin{array}{c}\text { Silva - Vergara et } \\
\text { al., } 2000\end{array}$ \\
\hline HCRPIBIAT2 & Tatu & $\begin{array}{c}\text { Baço, } \\
\text { Fígado e } \\
\text { Pulmão }\end{array}$ & lbiá - MG & P. brasiliensis sensu stricto $\mathrm{S} 1$ & P. brasiliensis sensu stricto $\mathrm{S} 1 \mathrm{~b}$ & MK909803 & $\begin{array}{c}\text { Silva - Vergara et } \\
\text { al., } 2000\end{array}$ \\
\hline HCRPIBIAT3 & Tatu & $\begin{array}{l}\text { Baço e } \\
\text { Pulmão }\end{array}$ & Ibiá - MG & P. brasiliensis sensu stricto $\mathrm{S} 1$ & P. brasiliensis sensu stricto $\mathrm{S} 1 \mathrm{~b}$ & MK909804 & $\begin{array}{c}\text { Silva - Vergara et } \\
\text { al., } 2000\end{array}$ \\
\hline
\end{tabular}

Legenda: MG - Estado de Minas Gerais. Autoria: Fonte Própria; Publicado na revista Journal of Fungi em 07/08/2020 - Cocio et al., 2020. 


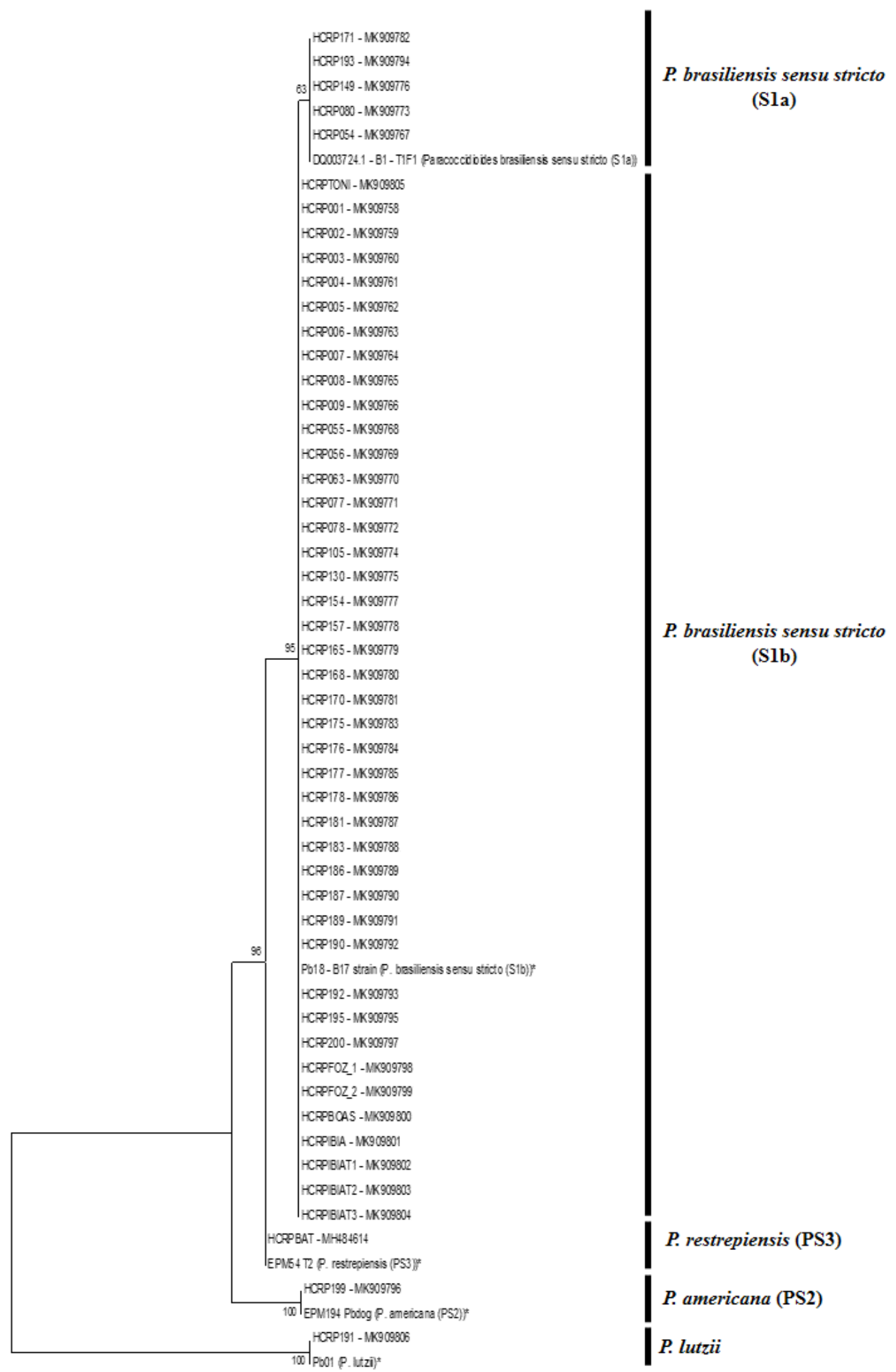

Figura 10: Análise filogenética gp43 exon 2 loci dos isolados clínicos e ambientais de Paracoccidioides spp. em comparação com as cepas de referência $\left({ }^{*}\right)$; que também foram sequenciadas para este estudo e tinham 100\% de identidade com as 
sequências depositadas no GenBank sob o número de acesso: [Pb18 — B17 — DQ003729.1 (P. brasiliensis sensu stricto (S1b); EPM194 - Pbdog - DQ003736.1 (P. americana (PS2); EPM54 - T2 - KT251008.1 ( $P$. restrepiensis (PS3); Pb01 EU870196.1 (P. lutzii)]. A história evolutiva foi medida pelo método de máxima verossimilhança $(\mathrm{ML})$ com base no modelo Kimura parâmetro. Autoria: Fonte Própria; Publicado na revista Journal of Fungi em 07/08/2020 - Cocio et al., 2020.

\subsubsection{Procedência geográfica dos pacientes e forma clínica de PCM}

Dos 46 isolados de origem clínica caracterizados genotipicamente neste estudo, 67,4\% dos pacientes manifestaram a forma crônica e 32,6\% manifestaram a forma sub-aguda da PCM. Avaliando a manifestação clínica da PCM por espécie do complexo $P$. brasiliensis e espécie $P$. lutzii, dos 46 isolados clínicos genotípados, 38 foram caracterizados como $P$. brasiliensis sensu stricto variante $\mathrm{S} 1 \mathrm{~b}$, cujos pacientes $65,8 \%$ apresentaram a forma crônica e 34,2\% a forma sub-aguda. Dos cinco isolados clínicos identificados como $P$. brasiliensis sensu stricto variante S1a, 60,0\% dos pacientes manifestaram a forma crônica e $40 \%$ a forma sub-aguda. Os pacientes dos isolados HCRP 191 (P. lutzii) e HCRP 199 (P. americana-PS2) apresentaram a forma crônica. HCRP BAT ( $P$. restrepiensis-PS3) foi isolado de paciente com a forma sub-aguda da doença (Tabela 3).

Analisando a procedência geográfica dos 46 pacientes, trinta e nove (39) residiam na cidade e região de Ribeirão Preto, SP, Brasil. Os pacientes dos isolados HCRP 063 ( $P$. brasiliensis sensu stricto S1b), HCRP 191 ( $P$. lutzii) e HCRP 199 ( $P$. americana-PS2) realizaram migração para Ribeirão Preto, SP, Brasil partindo de área anteriores de residência, respectivamente, os Estados do Maranhão, Mato Grosso e Paraná. Seis (6) pacientes adquiriram a PCM enquanto residiam em outras 
áreas endêmicas do Sudeste e Sul do Brasil (Estado de Minas Gerais - 4 e Estado do Paraná - 2) (Figura 11 e Tabela 3). 


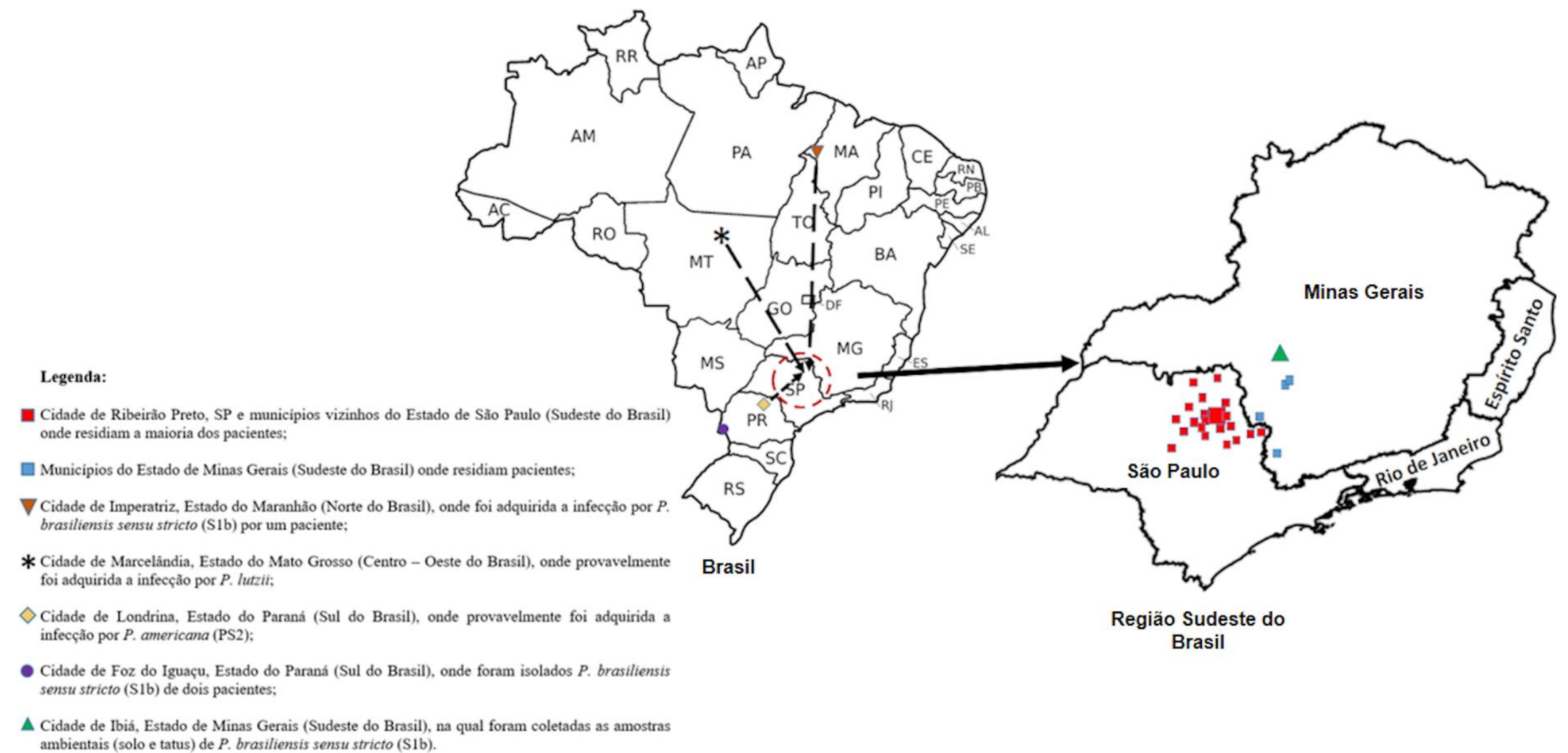

Autoria: Fonte Própria; Publicado na revista Journal of Fungi em 07/08/2020 - Cocio et al., 2020.

Figura 11. Mapa do Brasil, com destaque para os Estados de São Paulo e Minas Gerais, mostrando a área geográfica centrada por Ribeirão Preto, SP (1 $\left(\begin{array}{l}1 \\ \vdots\end{array}\right)$, onde residiam a maior parte dos pacientes, a migração de alguns pacientes que adquiriram a infecção por Paracoccidioides spp. em outras regiões (- - - - - $\rightarrow$ ) e o local de coleta dos isolados ambientais $(\boldsymbol{\Delta})$. 
Tabela 3. Forma clínica da PCM, residência dos pacientes e região brasileira onde provavelmente ocorreu a infecção por espécies do complexo $P$. brasiliensis e $P$. lutzii.

\begin{tabular}{|c|c|c|c|c|c|c|c|c|c|c|c|}
\hline \multirow{2}{*}{$\begin{array}{c}\text { Espécies } \\
\text { Paracoccidioides } \\
\text { spp. }\end{array}$} & \multirow[t]{2}{*}{$\begin{array}{l}\text { Número } \\
\text { Total }\end{array}$} & \multicolumn{2}{|c|}{ Forma Clínica - n (\%) } & \multicolumn{4}{|c|}{$\begin{array}{l}\text { Origem geográfica dos pacientes } \\
\text { com } P C M-n(\%)\end{array}$} & \multicolumn{4}{|c|}{$\begin{array}{l}\text { Local da infecção por Paracoccidioides } \\
\text { spp. nas regiões brasileiras - n }(\%)\end{array}$} \\
\hline & & Ag/Subaguda & Crônica & SP & MG & PR & MA & SE & $\mathbf{S}$ & $\mathbf{N E}$ & $\mathrm{CO}$ \\
\hline $\begin{array}{c}\text { P. brasiliensis } \\
\text { sensu stricto }(\mathrm{S} 1 \mathrm{~b})\end{array}$ & 38 & $13(34,2)$ & $25(65,8)$ & $31(81,6)$ & $4(10,5)$ & $2(5,3)$ & $1(2,6)$ & $35(92,1)$ & $2(5,3)$ & $1(2,6)$ & - \\
\hline $\begin{array}{c}\text { P. brasiliensis } \\
\text { sensu stricto }(\mathbf{S 1 a})\end{array}$ & 5 & $2(40,0)$ & $3(60,0)$ & $5(100,0)$ & - & - & - & $5(100,0)$ & - & - & - \\
\hline $\begin{array}{l}\text { P. americana } \\
\text { (PS2) }\end{array}$ & 1 & - & $1(100)$ & $1(100)$ & - & - & - & - & $1(100,0)$ & - & - \\
\hline $\begin{array}{l}\text { P. restrepiensis } \\
(\mathrm{PS3})\end{array}$ & 1 & $1(100)$ & - & $1(100)$ & - & - & - & $1(100,0)$ & - & - & - \\
\hline P. lutzii & 1 & - & $1(100)$ & $1(100)$ & - & - & - & - & - & - & $1(100,0)$ \\
\hline $\begin{array}{c}\text { P. brasiliensis } \\
\text { sensu stricto (S1b) } \\
*\end{array}$ & 4 & - & - & & $4(100)$ & & & $4(100,0)$ & - & - & - \\
\hline
\end{tabular}

Sudeste; S - Sul; NE - Nordeste; CO - Centro Oeste. (*): Isolados ambientais.

Autoria: Fonte Própria; Publicado na revista Journal of Fungi em 07/08/2020 - Cocio et al., 2020. 
5.2. Avaliação da antigenicidade de exoantígenos miceliais de cepas de referência $\mathrm{e}$ isolados clínicos de diferentes espécies do complexo $\boldsymbol{P}$. brasiliensis e de $P$. Iutzii

5.2.1. Seleção dos exoantígenos miceliais produzidos de diferentes cepas de referência e isolados clínicos do gênero Paracoccidioides spp.

Os exoantígenos miceliais que foram submetidos a avaliações sorológicas, dosagem e perfil proteico foram selecionados através da técnica IDD a partir da reação de imunoprecipitação frente a um pool de soros, utilizado como controle positivo. Os que tiveram a melhor antigenicidade frente ao pool de soros foram: Pb18: P. brasiliensis sensu stricto (S1b) - Agitação, 60 dias de incubação; EPM194 - Pbdog: P. americana (PS2) - Cultura estática, 30 dias de incubação; EPM54 - T2: P. restrepiensis (PS3) - Cultura estática, 60 dias de incubação; Pb01: P. lutzii Cultura estática, 60 dias de incubação; HCRP171: $P$. brasiliensis sensu stricto (S1a) - Agitação, 60 dias de incubação; HCRP199: P. americana (PS2) - Agitação, 60 dias de incubação; HCRP191: P lutzii - Agitação, 60 dias de incubação; HCRPBAT: P. restrepiensis (PS3) - Cultura estática, 60 dias de incubação (produzido em 07/07/1989).

Outros isolados e produtos de cultivos não foram avaliados quanto a antigenicidade por volume insuficiente, baixa reatividade frente ao pool de soros positivos ou contaminação de cultura.

\subsubsection{Concentração proteica dos produtos contendo exoantígenos miceliais de cepas de referência e clínica do gênero Paracoccidioides spp.}

Os exoantigenos miceliais de cada espécie do gênero Paracoccidioides spp. (Pb18: P. brasiliensis sensu stricto (S1b) - Agitação, 60 dias de incubação; EPM194 - Pbdog: P. americana (PS2) - Cultura estática, 30 dias de incubação; EPM54 - T2: 
P. restrepiensis (PS3) - Cultura estática, 60 dias de incubação; Pb01: P. lutzii Cultura estática, 60 dias de incubação; HCRP171: P. brasiliensis sensu stricto (S1a) - Agitação, 60 dias de incubação; HCRP199: P. americana (PS2) - Agitação, 60 dias de incubação; HCRP191: P lutzii - Agitação, 60 dias de incubação; HCRPBAT: P. restrepiensis (PS3) - Cultura estática, 60 dias de incubação) tiveram suas proteínas precipitadas e submetidas à quantificação de sua concentração pelo método de Bradford. As concentrações proteicas $(\mu \mathrm{g} / \mathrm{mL})$ de cada cepa de referência e clínica avaliadas neste estudo estão descritas na Tabela 4.

Tabela 4: Concentração proteica das cepas de referência e clínica de espécies de Paracoccidioides spp. e de $P$. lutzii.

\begin{tabular}{lc}
\multicolumn{1}{c}{ Amostras / Método e Período de incubação } & Concentração em \\
\hline Pb18: P. brasiliensis sensu stricto (S1b) - Agitação, 60 dias & $\mu \mathrm{g} / \mathbf{m L}$ \\
\hline HCRP171: P. brasiliensis sensu stricto (S1a) - Agitação, 60 dias & $\mathbf{1 1 , 2}$ \\
\hline EPM194 - Pbdog: P. americana (PS2) - Cultura estática, 30 dias & $\mathbf{2 8 , 3}$ \\
\hline HCRP199: P. americana (PS2) - Agitação, 60 dias & $\mathbf{1 2 7 , 5}$ \\
\hline EPM54 - T2: P. restrepiensis (PS3) - Cultura estática, 60 dias & $\mathbf{3 8 , 6}$ \\
\hline HCRPBAT: P. restrepiensis (PS3) - Cultura estática, 60 dias & $\mathbf{3 2 , 4}$ \\
\hline Pb01: P. lutzii - Cultura estática, 60 dias & $\mathbf{7 , 1}$ \\
\hline HCRP191: $P$ lutzii - Agitação, 60 dias & $\mathbf{9 , 8}$ \\
\hline Autoria: Fonte Próprla & $\mathbf{8 , 6}$ \\
\hline
\end{tabular}

Autoria: Fonte Própria 


\subsubsection{Análise de perfil de proteínas extracelulares contendo exoantígenos} miceliais de cepas de referência e clínica de espécies do gênero Paracoccidioides spp.

As proteínas extracelulares secretadas em meio liquido McVeigh e Morton das cepas avaliadas neste estudo foram separadas em gel de policrilamida SDS PAGE $10 \%$. Verificou-se que de um modo geral as cepas de referência produziram mais frações proteicas do que as clínicas, sugerindo a produção de exoantígenos miceliais em condições favoráveis de crescimento (Figura 12A). Foram observadas diversas frações entre 25 e 150 kDa, sendo feita a análise comparativa daquelas com 43, 60 e 70 kDa, conforme mostram a Tabela 5 e Figura 12B.

Tabela 5. Perfil proteico e intensidade de expressão dos isolados clínico e de referência de Paracoccidioides spp

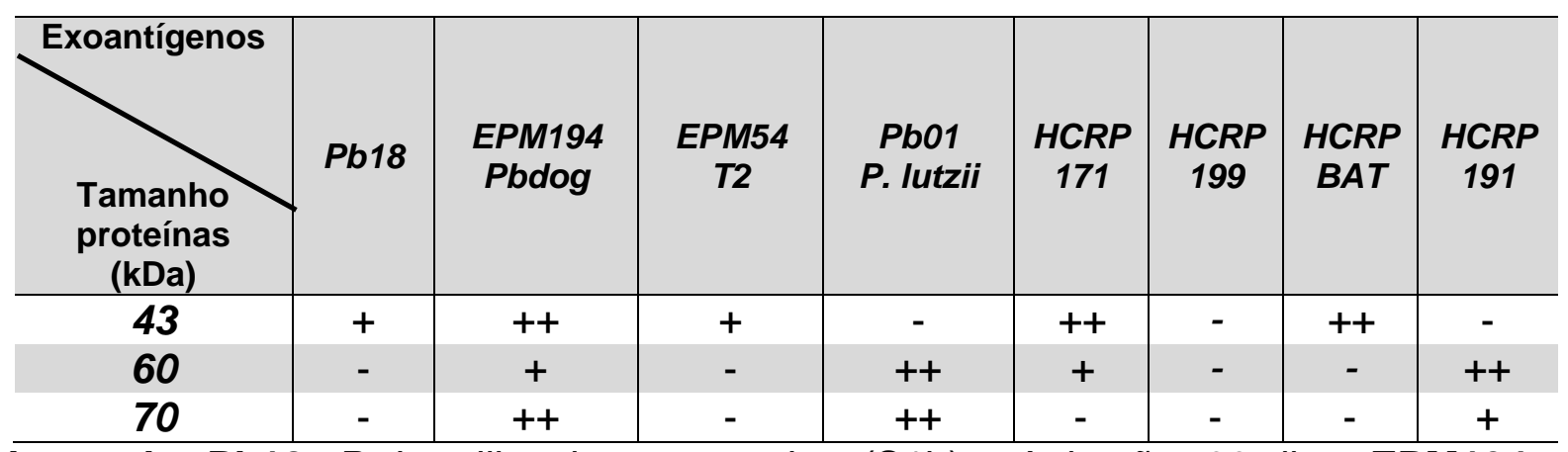

Legenda: Pb18: P. brasiliensis sensu stricto (S1b) - Agitação, 60 dias; EPM194 Pbdog: P. americana (PS2) - Cultura estática, 30 dias; EPM54 - T2: $P$. restrepiensis (PS3) - Cultura estática, 60 dias; Pb01: P. lutzii - Cultura estática, 60 dias; HCRP171: P. brasiliensis sensu stricto (S1a) - Agitação, 60 dias; HCRP199: P. americana (PS2) - Agitação, 60 dias; HCRPBAT: P. restrepiensis (PS3) - Cultura estática, 60 dias; HCRP191: P. lutzii - Agitação, 60 dias. (+) baixo nível de expressão; (++) alto nível de expressão; (-) ausência de expressão. Autoria: Fonte Própria 
Figura 12. Gel de Policrilamida SDS - PAGE 10\% para a avaliação do perfil proteico dos produtos extracelulares de espécies do gênero Paracoccidioides spp. avaliados neste estudo.

A.
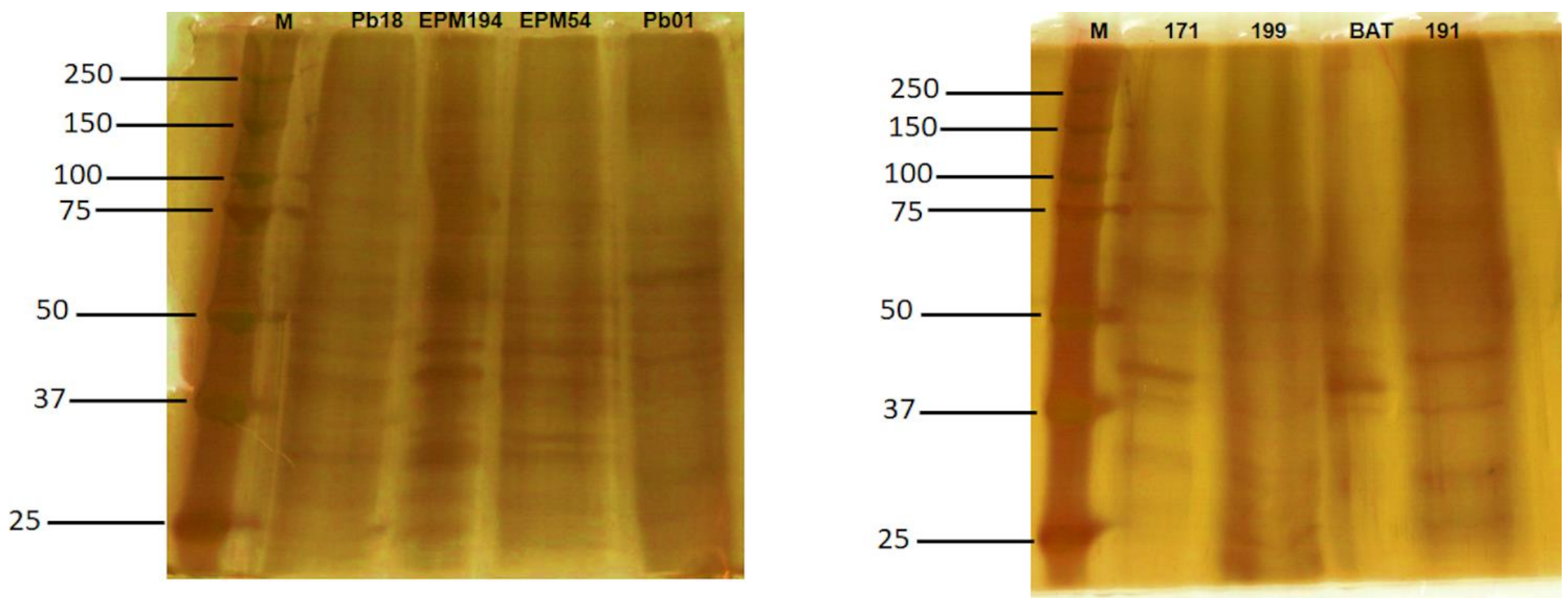

Legenda: A. Gel sem demarcação dos tamanhos aproximados em kDa. M: Marcador de peso molecular. Pb18: $P$. brasiliensis sensu stricto (S1b) - Agitação, 60 dias; EPM194 - Pbdog: P. americana (PS2) - Cultura estática, 30 dias; EPM54 - T2: $P$. restrepiensis (PS3) - Cultura estática, 60 dias; Pb01: $P$. lutzii - Cultura estática, 60 dias; HCRP171: $P$. brasiliensis sensu stricto (S1a) - Agitação, 60 dias; HCRP199: P. americana (PS2) - Agitação, 60 dias; HCRPBAT: P. restrepiensis (PS3) - Cultura estática, 60 dias; HCRP191: P lutzii - Agitação, 60 dias. Autoria: Fonte Própria. 
Figura 12. Gel de Policrilamida SDS - PAGE 10\% para a avaliação do perfil proteico dos produtos extracelulares de espécies do gênero Paracoccidioides spp. avaliados neste estudo. Continuação.

B.

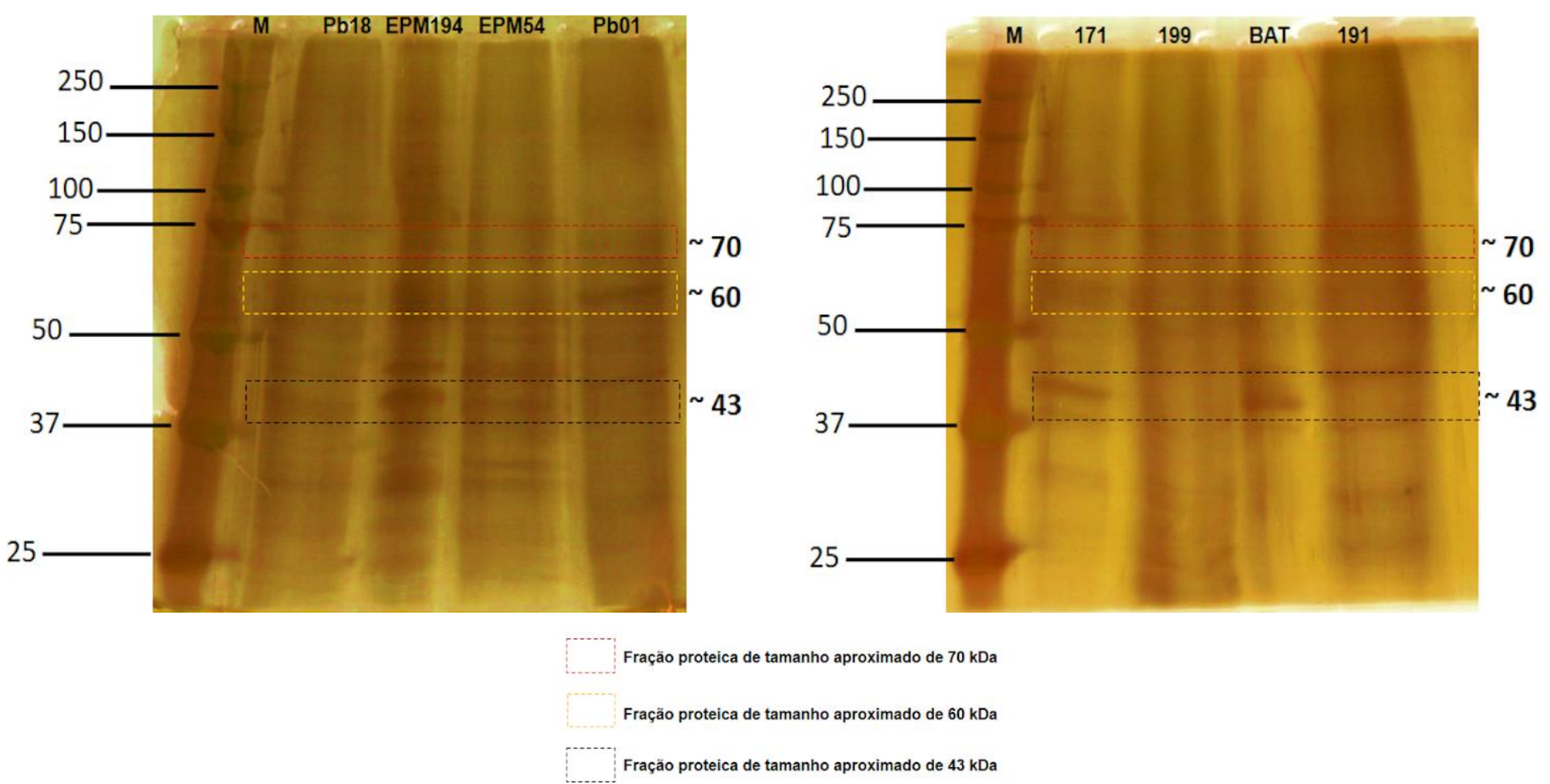

Legenda: B. Gel com demarcação dos tamanhos aproximados $(\mathrm{kDa})$ dos possíveis antígenos produzidos. M: Marcador de peso molecular. Pb18: P. brasiliensis sensu stricto (S1b) - Agitação, 60 dias; EPM194 - Pbdog: P. americana (PS2) - Cultura estática, 30 dias; EPM54 - T2: P. restrepiensis (PS3) - Cultura estática, 60 dias; Pb01: P. lutzii - Cultura estática, 60 dias; HCRP171: P. brasiliensis sensu stricto (S1a) Agitação, 60 dias; HCRP199: P. americana (PS2) - Agitação, 60 dias; HCRPBAT: P. restrepiensis (PS3) - Cultura estática, 60 dias; HCRP191: P lutzii - Agitação, 60 dias. Autoria: Fonte Própria. 


\subsubsection{Antigenicidade dos exoantígenos miceliais produzidos por diferentes espécies de cepas de referência e clínicas de Paracoccidioides spp. frente soros de pacientes}

No total foram testados soros de 15 pacientes com PCM e cujos isolados fúngicos tiveram seus genótipos identificados (Anexo 2 - Tabela Suplementar 2). Pela técnica IDD foi possível observar que os exoantígenos miceliais produzidos a partir de cepas de referência e clínicas e que pertencem a espécies do complexo $P$. brasiliensis ( $P$. brasiliensis sensu stricto (S1), $P$. americana (PS2) e $P$. restrepiensis (PS3) tiveram reação positiva, formando uma ou duas bandas de imunoprecipitado com todos os soros testados (100\%) (Tabela 6 e Figuras 13, 14 e 15). Pb01 ( $P$. lutzii) não apresentou reatividade com os soros 14 e 15 (Tabela 6 e Figura 15). HCRP191 (P. lutzii) não apresentou reatividade com os soros 1, 2, 3, 6, 7, 10, 13 e 15 (Tabela 6 e Figuras 13, 14 e 15). Os exoantígenos miceliais produzidos pela cepa de referência Pb01 (P.lutzii) e HCRP191 ( $P$. lutzii) tiveram detecção de anticorpos de $86,7 \%$, e $53,3 \%$, respectivamente. Além da presença de bandas, foi avaliada a identidade das linhas de precipitação entre os diferentes exoantígenos colocados nos poços periféricos. Observa-se que para a maioria dos soros existe identidade entre as bandas de precipitado, principalmente no teste com os exoantígenos de cepas do complexo P. brasiliensis (Figuras 13, 14 e 15). Os soros 4, 6, 9 e 12 apresentaram uma linha de precipitação mais fraca e próxima ao poço do soro, onde o imunoprecipitado produzido por Pb01 ( $P$. lutzii) (poço E) não tem identidade com os demais, formados na reação com exoantígenos do complexo $P$. brasiliensis, sugerindo uma reação com molécula antigênica diferente (Figuras 13, 14 e 15). O mesmo aspecto de não identidade foi observado com o exoantígeno HCRP191 ( $P$. lutzii) (poço $\mathrm{H}$ ) reagindo com os soros 4 e 14 (Figura 13 e 15). O soro 10, de 
paciente cujo o isolado fúngico foi identificado como $P$. lutzii, reagiu com todos os exoantígenos miceliais testados, porém com linha de precipitação mais localizada próximo ao poço central (soro) e com baixa intensidade na reatividade, sugerindo conter um anticorpo em baixo título contra fração antigênica presente em todos exoantígenos avaliados, porém provavelmente diferente da fração antigênica principal reconhecida pelos soros de pacientes infectados pelo complexo $P$. brasiliensis (Figuras 13, 14 e 15).

A antigenicidade de exoantígenos miceliais do complexo $P$. brasiliensis e espécie $P$. Iutzii foi também avaliada utilizando a técnica de CIE, onde foram testados frente aos soros 1, 5, 10, 13 e 15, cujos isolados fúngicos obtidos dos respectivos pacientes foram identificados como $P$. brasiliensis sensu stricto (S1a e S1b), $P$. americana (PS2), $P$. lutzii e $P$. restrepiensis (PS3). Observou-se que para os soros testados, os exoantígenos miceliais produzidos por espécies do complexo P. brasiliensis mostraram reatividade com todos (100\%). O exoantígeno Pb01 ( $P$. lutzii) não foi reativo com os soros 1, 5, 13 e 15, mas positivo com o soro 10, tendo uma reatividade de $20 \%$ (Tabela 8 ). O exoantígeno HCRP191 ( $P$. lutzii) foi reativo somente com o soro 1, apresentando a mesma porcentagem de reatividade de $\mathrm{Pb01}$ (P. lutzii), 20\% (Tabela 8).

Relacionando os resultados obtidos pelas técnicas IDD e CIE observamos que os exoantígenos miceliais produzidos a partir das espécies do complexo $P$. brasiliensis tiveram $100 \%$ de reatividade frente aos soros testados em ambas as técnicas sorológicas (Tabela 9). Os exoantigenos miceliais produzidos a partir da cepa de referência Pb01 ( $P$. lutzii) e por HCRP191, tiveram comportamento antigênico diferente, sendo mais reativos na IDD do que na CIE (Tabela 9). 
Figura 13. Imunodifusão dupla de exoantígenos miceliais de espécies do complexo $P$. brasiliensis e $P$. lutzii frente a soros 1 a 6 de pacientes com PCM.

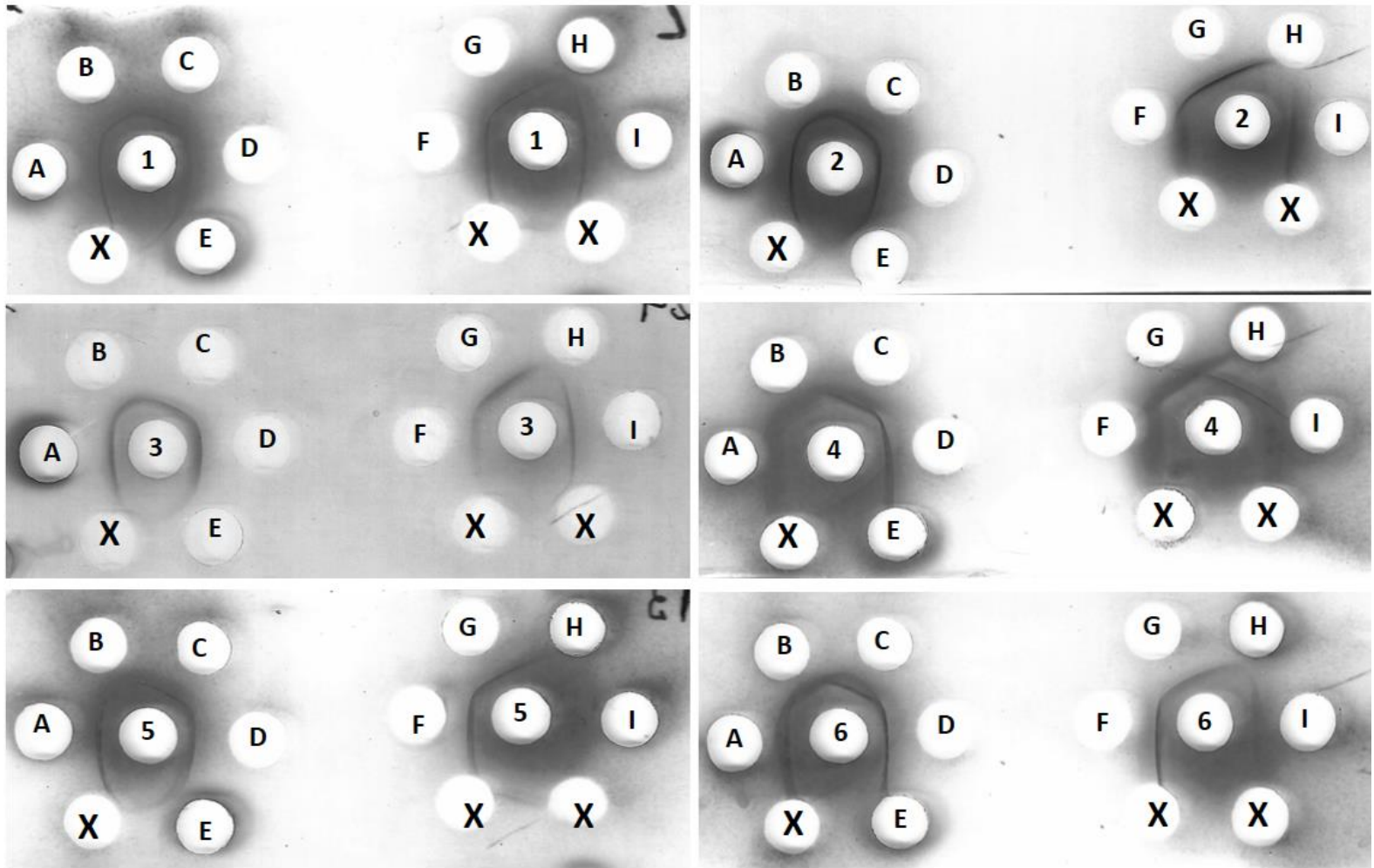

Legenda: Soros de pacientes testados de 1 a 6; Exoantígenos miceliais: A: pool de antígenos obtidos por sonicação de leveduras de Paracoccidioides spp. (Controle); B: Pb18: P. brasiliensis sensu stricto (S1b) - Agitação 60 dias; C: EPM194 - Pbdog: P. americana (PS2) - Estática 30 dias; D: EPM54 - T2: P. restrepiensis (PS3) Estática 60 dias; E: Pb01: P. lutzii - Estática 60 dias; B: Pb18 - P. brasiliensis sensu stricto (S1b); C: EPM194 - Pbdog - P. americana (PS2); D: EPM54 - T2 - P. restrepiensis (PS3); E: Pb01 - P. lutzii; F: HCRPBAT - P. restrepiensis (PS3); G: HCRP171 - P. brasiliensis sensu stricto (S1a); H: HCRP191 - P. lutzii; I: HCRP199 P. americana (PS2) e X: poço vazio, sem aplicação de antígenos. Autoria: Fonte Própria. 
Figura 14. Imunodifusão dupla de exoantígenos miceliais de espécies do complexo $P$. brasiliensis e $P$. lutzii frente a soros 7 a 12 de pacientes com PCM

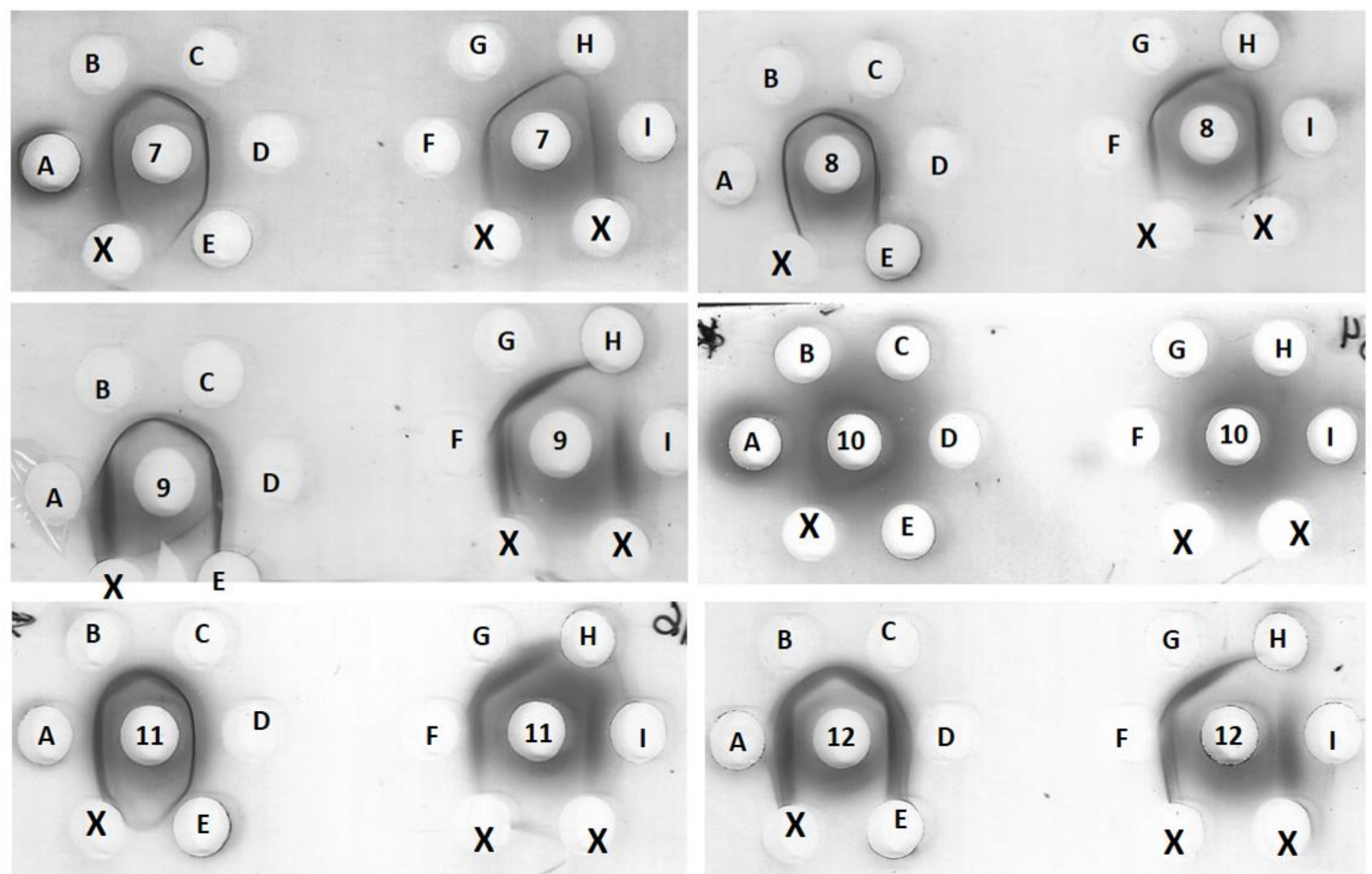

Legenda: Soros de pacientes testados de 7 a 12; Exoantígenos miceliais: A: pool de antígenos obtidos por sonicação de leveduras de Paracoccidioides spp. (Controle); B: Pb18: P. brasiliensis sensu stricto (S1b) - Agitação 60 dias; C: EPM194 - Pbdog: P. americana (PS2) - Estática 30 dias; D: EPM54 - T2: P. restrepiensis (PS3) Estática 60 dias; E: Pb01: P. lutzii - Estática 60 dias; B: Pb18 - P. brasiliensis sensu stricto (S1b); C: EPM194 - Pbdog - P. americana (PS2); D: EPM54 - T2 - P. restrepiensis (PS3); E: Pb01 - P. lutzii; F: HCRPBAT - P. restrepiensis (PS3); G: HCRP171 - P. brasiliensis sensu stricto (S1a); H: HCRP191 - P. lutzii; I: HCRP199 P. americana (PS2) e X: poço vazio, sem aplicação de antígenos. Autoria: Fonte Própria. 
Figura 15. Imunodifusão dupla de exoantígenos miceliais de espécies do complexo $P$. brasiliensis e $P$. lutzii frente a soros 13 a 15 de pacientes com PCM

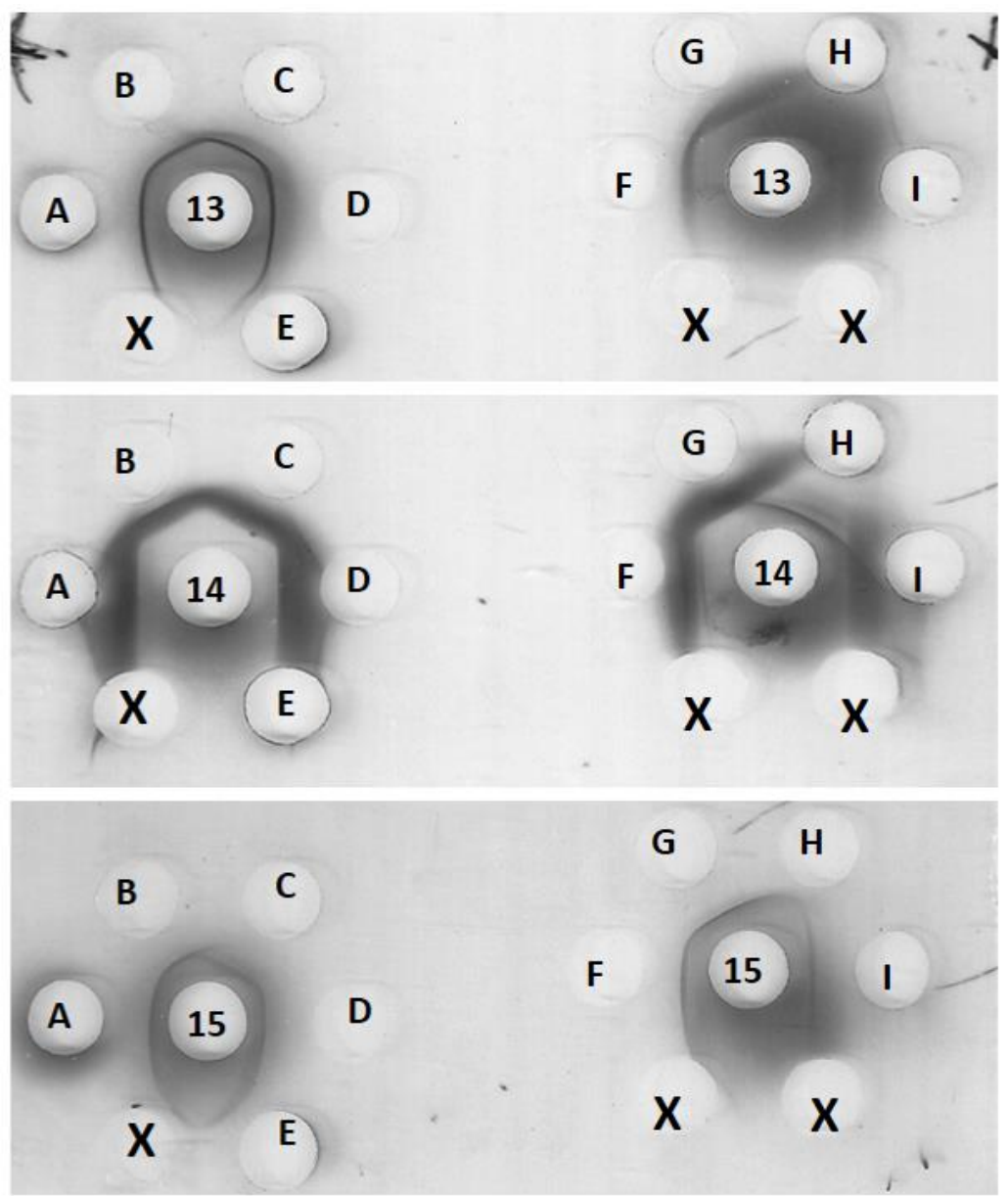

Legenda: Soros de pacientes testados de 13 a 15; Exoantígenos miceliais: A: pool de antígenos obtidos por sonicação de leveduras de Paracoccidioides spp. (Controle); B: Pb18: P. brasiliensis sensu stricto (S1b) - Agitação 60 dias; C: EPM194 - Pbdog: P. americana (PS2) - Estática 30 dias; D: EPM54 - T2: P. restrepiensis (PS3) - Estática 60 dias; E: Pb01: P. lutzii - Estática 60 dias; B: Pb18 P. brasiliensis sensu stricto (S1b); C: EPM194 - Pbdog - P. americana (PS2); D: EPM54 - T2 - P. restrepiensis (PS3); E: Pb01 - P. lutzii; F: HCRPBAT - P. restrepiensis (PS3); G: HCRP171 - P. brasiliensis sensu stricto (S1a); H: HCRP191 - P. lutzii; I: HCRP199 - P. americana (PS2) e X: poço vazio, sem aplicação de antígenos. Autoria: Fonte Própria. 
Tabela 6. Detecção de anticorpos pelo método de imunodifusão dupla (IDD) com uso de exoantigenos miceliais de espécies do gênero Paracoccidioides spp. em soros de pacientes com PCM.

\begin{tabular}{|c|c|c|c|c|c|c|c|c|}
\hline Exoantigenos & Pb18 & $\begin{array}{c}\text { EPM194 } \\
\text { Pbdog }\end{array}$ & $\begin{array}{c}\text { EPM54 } \\
\text { T2 }\end{array}$ & $\begin{array}{c}\text { Pb01 } \\
\text { P. } \\
\text { Iutzii }\end{array}$ & $\begin{array}{c}H C R P \\
171\end{array}$ & $\begin{array}{c}\text { HCRP } \\
199\end{array}$ & $\begin{array}{c}H C R P \\
B A T\end{array}$ & $\begin{array}{c}H C R P \\
191\end{array}$ \\
\hline 1 & + & + & + & + & + & + & + & - \\
\hline 2 & + & + & + & + & + & + & + & - \\
\hline 3 & + & + & + & + & + & + & + & - \\
\hline 4 & + & + & + & + & + & + & + & + \\
\hline 5 & + & + & + & + & + & + & + & + \\
\hline 6 & + & + & + & + & + & + & + & - \\
\hline 7 & + & + & + & + & + & + & + & - \\
\hline 8 & + & + & + & + & + & + & + & + \\
\hline 9 & + & + & + & + & + & + & + & + \\
\hline 10 & + & + & + & + & + & + & + & + \\
\hline 11 & + & + & + & + & + & + & + & + \\
\hline 12 & + & + & + & + & + & + & + & + \\
\hline 13 & + & + & + & + & + & + & + & - \\
\hline 14 & + & + & + & - & + & + & + & + \\
\hline 15 & + & + & + & - & + & + & + & - \\
\hline
\end{tabular}

Legenda: Soros de pacientes testados na IDD: 1 a 15. Exoantígenos - Pb18: $P$. brasiliensis sensu stricto (S1b) - Agitação, 60 dias; EPM194 - Pbdog: P. americana (PS2) - Cultura estática, 30 dias; EPM54 - T2: P. restrepiensis (PS3) - Cultura estática, 60 dias; Pb01: P. lutzii - Cultura estática, 60 dias; HCRP171: P. brasiliensis sensu stricto (S1a) - Agitação, 60 dias; HCRP199: P. americana (PS2) - Agitação, 60 dias HCRPBAT: $P$. restrepiensis (PS3) - Cultura estática, 60 dias; HCRP191: $P$. lutzii - Agitação, 60 dias. (+): Soros com reação positiva; (-): Soros com reação negativa. Autoria: Fonte própria. 
Tabela 7. Positividade de 15 soros de PCM testados pelo método imunodifusão dupla (IDD) contra exoantígenos miceliais de diferentes cepas de referência e clínica de Paracoccidioides spp.

\begin{tabular}{|c|c|c|c|c|c|c|c|c}
\hline Exoantígenos & Pb18 & $\begin{array}{c}\text { EPM194 } \\
\text { Pbdog }\end{array}$ & $\begin{array}{c}\text { EPM54 } \\
\text { T2 }\end{array}$ & $\begin{array}{c}\text { Pb01 } \\
\boldsymbol{P} \text {. lutzii }\end{array}$ & $\begin{array}{c}\text { HCRP } \\
\mathbf{1 7 1}\end{array}$ & $\begin{array}{c}\text { HCRP } \\
\mathbf{1 9 9}\end{array}$ & $\begin{array}{c}\text { HCRP } \\
\text { BAT }\end{array}$ & $\begin{array}{c}\text { HCRP } \\
\mathbf{1 9 1}\end{array}$ \\
\hline $\begin{array}{c}\text { Resultados } \\
\text { Positiva }\end{array}$ & $\begin{array}{c}15(100,0) \\
\text { Negativa }\end{array}$ & $\begin{array}{c}15(100,0) \\
0(0,0)\end{array}$ & $\begin{array}{c}15(100,0) \\
0(0,0)\end{array}$ & $\begin{array}{c}13(86,7) \\
2(13,3)\end{array}$ & $\begin{array}{c}15(100,0) \\
0(0,0)\end{array}$ & $\begin{array}{c}15(100,0) \\
0(0,0)\end{array}$ & $\begin{array}{c}15(100,0) \\
0(0,0)\end{array}$ & $\begin{array}{c}8(53,3) \\
7(46,7)\end{array}$ \\
\hline
\end{tabular}

Legenda: Pb18: P. brasiliensis sensu stricto (S1b) - Agitação, 60 dias; EPM194 Pbdog: P. americana (PS2) - Cultura estática, 30 dias; EPM54 - T2: $P$. restrepiensis (PS3) - Cultura estática, 60 dias; Pb01: P. lutzii - Cultura estática, 60 dias; HCRP171: P. brasiliensis sensu stricto (S1a) - Agitação, 60 dias; HCRP199: P. americana (PS2) - Agitação, 60 dias HCRPBAT: P. restrepiensis (PS3) - Cultura estática, 60 dias; HCRP191: P. lutzii - Agitação, 60 dias. Autoria: Fonte Própria.

Tabela 8. Positividade de 5 soros de PCM testados pelo método contraimunoeletroforese $(\mathrm{CIE})$ frente aos exoantígenos miceliais de cepas de referência e clínicas de Paracoccidioides spp.

\begin{tabular}{|c|c|c|c|c|c|c|c|c}
\hline Exoantígenos & Pb18 & $\begin{array}{c}\text { EPM194 } \\
\text { Pbdog }\end{array}$ & $\begin{array}{c}\text { EPM54 } \\
\text { T2 }\end{array}$ & $\begin{array}{c}\text { Pb01 } \\
\text { P. lutzii }\end{array}$ & $\begin{array}{c}\text { HCRP } \\
\mathbf{1 7 1}\end{array}$ & $\begin{array}{c}\text { HCRP } \\
\mathbf{1 9 9}\end{array}$ & $\begin{array}{c}\text { HCRP } \\
\text { BAT }\end{array}$ & $\begin{array}{c}\text { HCRP } \\
\mathbf{1 9 1}\end{array}$ \\
\hline $\begin{array}{c}\text { Reação } \\
\text { Positiva }\end{array}$ & $\begin{array}{c}5(100,0) \\
\text { Negativa }\end{array}$ & $\begin{array}{c}5(100,0) \\
0(0,0)\end{array}$ & $\begin{array}{c}5(100,0) \\
0(0,0)\end{array}$ & $\begin{array}{l}1(20,0) \\
4(80,0)\end{array}$ & $\begin{array}{c}5(100,0) \\
0(0,0)\end{array}$ & $\begin{array}{c}5(100,0) \\
0(0,0)\end{array}$ & $\begin{array}{c}5(100,0) \\
0(0,0)\end{array}$ & $\begin{array}{c}1(20,0) \\
4(80,0)\end{array}$ \\
\hline
\end{tabular}

Legenda: Pb18: P. brasiliensis sensu stricto (S1b) - Agitação, 60 dias; EPM194 Pbdog: P. americana (PS2) - Cultura estática, 30 dias; EPM54 - T2: $P$. restrepiensis (PS3) - Cultura estática, 60 dias; Pb01: P. lutzii - Cultura estática, 60 dias; HCRP171: P. brasiliensis sensu stricto (S1a) - Agitação, 60 dias; HCRP199: P. americana (PS2) - Agitação, 60 dias HCRPBAT: P. restrepiensis (PS3) - Cultura estática, 60 dias; HCRP191: P. lutzii - Agitação, 60 dias. Autoria: Fonte Própria. 
Tabela 9. Comparação da detecção de anticorpos específicos em cinco soros de PCM conforme as espécies de Paracoccidioides spp. e as técnicas de IDD e CIE.

\begin{tabular}{c|c|c|c}
\hline Exoantígenos & Espécies do complexo P. brasiliensis & $\begin{array}{c}\boldsymbol{P} \text { Pb01 } \\
\text { P. lutzii }\end{array}$ & $\begin{array}{c}\boldsymbol{H C R} \\
\mathbf{1 9 1}\end{array}$ \\
\hline Reação & & $86,7 \%$ & $53,3 \%$ \\
\hline IDD & $100 \%$ & $20 \%$ & $20 \%$ \\
\hline
\end{tabular}

Legenda: Espécies do complexo P. brasiliensis - Pb18: P. brasiliensis sensu stricto (S1b) - Agitação, 60 dias; EPM194 - Pbdog: P. americana (PS2) - Cultura estática, 30 dias; EPM54 - T2: P. restrepiensis (PS3) - Cultura estática, 60 dias; HCRPBAT: P. restrepiensis (PS3) - Cultura estática, 60 dias; HCRP171: $P$. brasiliensis sensu stricto (S1a) - Agitação, 60 dias; HCRP199: P. americana (PS2) Agitação, 60 dias. (PS2) e Espécie P. Iutzii - Pb01: P. lutzii - Cultura estática, 60 dias; HCRP191: P lutzii - Agitação, 60 dias. Autoria: Fonte Própria. 


\section{DISCUSSÃO}




\section{DISCUSSÃO}

\subsection{Espécies filogenéticas de Paracoccidioides spp. isoladas de amostras clínicas e ambientais em área hiperendêmica de paracoccidioidomicose no sudeste do Brasil.}

A eco - epidemiologia de espécies do complexo $P$. brasiliensis e $P$. lutzii tem o conhecimento de sua distribuição geográfica dificultado devido a fatores como a migração de pacientes entre diferentes regiões endêmicas da PCM, o longo período de latência da forma crônica da PCM e a dificuldade de obter isolados ambientais (solo) e clínicos desse fungo (THEODORO et al., 2012). O primeiro objetivo deste estudo foi avaliar genotipicamente isolados clínicos e ambientais de Paracoccidioides spp. provenientes de uma única e definida área endêmica de PCM, abrangendo parcialmente os estados de São Paulo e Minas Gerais, no sudeste brasileiro (BELLISSIMO - RODRIGUES et al., 2011; SILVA - VERGARA et al., 2000; SILVA - VERGARA et al., 1998). Adicionalmente, dois isolados de pacientes da região de Foz do Iguaçu, PR, sul do Brasil também foram avaliados.

Dos isolados clínicos caracterizados genotipicamente neste estudo, observouse maior prevalência da espécie $P$. brasiliensis sensu stricto (S1a e S1b) na cidade e região de Ribeirão Preto, SP, Brasil, assim confirmando relatos na literatura sobre a alta incidência desta espécie filogenética na América do Sul e no Brasil, particularmente na região Sudeste e Sul (HRYCYK et al., 2018; SHIKANAI-YASUDA et al., 2017; GEGEMBAUER et al., 2014). A variedade prevalente de $P$. brasiliensis sensu stricto entre os isolados clínicos avaliados neste estudo é S1b, que foi identificado em $38 / 46(82,6 \%)$ dos pacientes. Exceto um paciente que aparentemente adquiriu a infecção fúngica no estado do Maranhão, os demais pacientes residiam nos estados de São Paulo, Minas Gerais e Paraná. A variante S1a foi identificada em 5/46 pacientes com procedência geográfica de cidades da 
região de Ribeirão Preto, SP (Tabela 4). A distribuição geográfica conjunta de $P$. brasiliensis sensu stricto S1a e S1b mostra que 40/43 indivíduos permaneceram em estados do Sudeste desde o nascimento ou se deslocaram dos estados contíguos de Minas Gerais e do Paraná para a região de Ribeirão Preto, SP, Brasil onde manifestaram a PCM (Figura 7). Não foi encontrada relação entre a área geográfica de residência dos pacientes e as variantes genotípicas $\mathrm{S} 1 \mathrm{a}$ e ou $\mathrm{S} 1 \mathrm{~b}$ de $P$. brasiliensis sensu stricto. Em um dos casos de PCM ocasionado por P. brasiliensis sensu stricto S1b (isolado HCRP 170 - Tabela 3), o paciente tinha AIDS e teve várias recidivas de PCM oportunista até o seu óbito. A prevalência de $P$. brasiliensis sensu stricto em países da América do Sul foi mostrada em um estudo filogenético e populacional utilizando genomas completos de 31 isolados clínicos de Paracoccidioides spp. de diferentes regiões de alguns países deste continente, no qual identificou - se P. brasiliensis sensu stricto S1a como variante predominante na Argentina e que a variante S1b distribuiu-se entre o Paraguai e Argentina (TEIXEIRA et al., 2020). Ainda neste estudo foi evidenciada a ocorrência de genótipos com algum grau de mistura (admixed) entre S1a e S1b (TEIXEIRA et al., 2020). Dessa forma, é importante ressaltar que a diferenciação e/ou classificação entre os genótipos S1a e S1b baseada apenas em dois marcadores moleculares empregados (padrão RFLP do gene tub1 e polimorfismo de gp43 exon 2 loci) pode levar a resultados diferentes daquele obtidos pela análise do genoma completo, porém sem alterar a classificação no grupo S1. Portanto, a diferenciação das variantes de $P$. brasiliensis sensu stricto (S1a e $\mathrm{S} 1 \mathrm{~b}$ ) realizadas neste estudo tem a limitação de metodologia empregada.

A espécie filogenética PS2 ( $P$. americana) tem sido isolada com menor prevalência de pacientes e amostras ambientais nas áreas endêmicas da região Sul 
(Estados do Paraná e Rio Grande do Sul) e Sudeste do país (Estados de Minas Gerias, São Paulo e Rio de Janeiro) (DE MACEDO et al., 2019; HRYCYK et al., 2018; ROBERTO et al., 2016; LENHARD-VIDAL et al. 2013; THEODORO et al. 2012; MATUTE et al., 2006). O isolado HCRP 199 (P. americana - PS2) avaliado neste estudo, foi obtido de paciente masculino de 57 anos que apresentou a forma crônica da PCM, e embora residente em Ribeirão Preto, SP, tinha vivido longo tempo no estado do Paraná (cidade de Londrina). $P$. americana (PS2) também foi isolado de cão com linfadenomegalia generalizada em Curitiba, PR (de FARIAS et al., 2011). Adicionalmente, em regiões rurais da cidade de Botucatu, SP, $P$. americana (PS2) foi isolado de tatus, mostrando que esta espécie é endêmica no sudeste do Brasil (HRYCYK et al., 2018). Recentemente, ocorreu no estado do Rio de Janeiro o isolamento de $P$. americana (PS2) em pacientes apresentando a forma crônica de PCM (de MACEDO et al., 2019). Em outros países da América Latina, como Venezuela, Uruguai e Argentina também foi isolada a espécie $P$. americana (PS2) de pacientes com PCM (ROBERTO et al., 2016).

Outra espécie que tem sido identificada em áreas endêmicas do Brasil é $P$. restrepiensis (PS3), que possuí distribuição geográfica centrada na Colômbia. O isolado HCRP BAT, identificado como genótipo PS3, foi obtido de um paciente de 33 anos, do sexo masculino, que apresentou a forma sub-aguda da PCM. O paciente, que nasceu e morava em uma cidade da região de Ribeirão Preto, SP, não possuía históricos de viagens para outras regiões geográficas do território brasileiro e países da América Latina, sugerindo aquisição do fungo naquela região do sudeste do Brasil. Independentemente, o isolado HCRP BAT (também denominado Pb 327-B) já tinha sido avaliado juntamente com amostras de $P$. brasiliensis de diferentes países da América do Sul utilizando técnicas como RAPD e RFLP, onde foi agrupado 
próximo a isolados de $P$. brasiliensis (PS3) exclusivos da Colômbia (NINO - VEJA et al., 2000; CALCAGNO et al., 1998). Recentemente, foram identificados como $P$. restrepiensis (PS3) dois isolados de pacientes da cidade de Botucatu, localizado na região centro - oeste do estado de São Paulo, mostrando presença deste genótipo na região Sudeste do Brasil (PEREIRA et al., 2021). Além do estado de São Paulo, foram identificados como $P$. restrepiensis (PS3) três (3) isolados clínicos da região Centro Oeste (estado do Mato Grosso do Sul), ressaltando - se que um dos pacientes migrou do estado do Paraná (região Sul do Brasil) (MATTOS et al., 2021). Em países da América Latina, como Argentina e Peru, foi também identificado casos de PCM por P. restrepiensis (PS3) (TEIXEIRA et al., 2020). Com o surgimento de evidências da presença da espécie filogenética PS3 em outra regiões, observa-se que este genótipo não está mais restrito ao território colombiano, podendo ter ocorrido uma distribuição de $P$. restrepiensis (PS3) para outros países da América do Sul. Sugeriu-se que as características filogeográficas de $P$. restrepiensis (PS3) sejam devido a possível expansão biogeográfica relativamente recente de S1 para o território colombiano, associado a eventos de barreiras geográficas representadas pelo surgimento da cordilheira dos Andes e submersão do território pela formação do lago Pebas-Solimões (TEIXEIRA et al., 2014a; WESSELINGH et al., 2006). O surgimento de $P$. restrepiensis (PS3) no Brasil não está esclarecido dentro do processo de especiação destas filogenias, devido à ausência de barreira geográfica no território brasileiro (TEIXEIRA et al., 2014a).

A espécie $P$. lutzii possui distribuição geográfica predominante na região Centro-Oeste do Brasil, nos estados de Mato Grosso, Mato Grosso do Sul e Goiás, e não é usual o seu isolamento no sudeste brasileiro (HAHN et al., 2019; GEGEMBAUER et al., 2014). O isolado HCRP 191 (P. lutzii) foi obtido de um 
paciente do sexo masculino de 55 anos, que apresentou a forma crônica da PCM. Era morador da cidade de Ribeirão Preto, SP, Brasil, contudo tinha nascido no estado do Paraná, região Sul e tinha histórico de trabalho e residência por longo tempo em áreas rurais de municípios da região Centro - Oeste, onde provavelmente adquiriu a infecção fúngica, que se manifestou como PCM anos mais tarde, na região Sudeste do Brasil. É possível que $P$. lutzii viva saprofíticamente no Sudeste e Sul do Brasil, pois o isolado denominado IFM 54648 (ou LDR 2) genotipicamente similar a Pb01 ( $P$. lutzii), foi obtido de paciente residente em Londrina, $\mathrm{PR}$, mas que também tinha residido em Botucatu, SP (TAKAIAMA et al., 2010). Ademais, vestígios moleculares de $P$. lutzii foram encontrados em amostras de solo e aerosol de tocas de tatus na região Sudeste do Brasil - Estado de São Paulo e Minas Gerais (ARANTES et al., 2016; ARANTES et al., 2013), sugerindo que esta espécie não é encontrada exclusivamente na região Centro - Oeste do Brasil.

Os isolados ambientais aqui avaliados foram coletados há aproximadamente 20 anos na cidade de Ibiá, estado de Minas Gerais, e mantidos desde então no local deste estudo. O isolado lbiá é proveniente de solo de plantação de café e os outros três isolados (lbiá T1, Ibiá T2 e Ibiá T3) foram obtidos de tatus (Dasypus novemcinctus) capturados no mesmo município, cujo território é vizinho de região onde pacientes tiveram PCM (SILVA - VERGARA et al., 1998; SILVA - VERGARA et al., 2000). Ibiá T1 (denominado EPM 101) foi previamente identificado como $P$. brasiliensis sensu stricto pelo método PCR - RFLP do gene tub1 (ROBERTO et al., 2016). Um estudo filogenético que inclui amostras de solo e de tatus coletados na cidade de Botucatu, SP, mostrou que $P$. brasiliensis sensu stricto S1a e S1b considerados principais agentes da PCM humana, foram também observados em amostras ambientais do Sudeste do Brasil, utilizando três marcadores moleculares 
(padrão RFLP do gene tub1, polimorfismo de gp43 exon 2 loci e sequenciamento da região ITS1-5.8S-ITS2 rDNA) (HRYCYK et al., 2018). Em um recente trabalho, Bagagli et al. (2021) realizaram sequenciamento de nova geração (NGS) de nove isolados coletados de tatus (Dasypus novemcinctus) das regiões Amazônica, cidade de Botucatu (região Sudeste) e do estado do Mato Grosso (região Centro Oeste). Cinco (5) isolados coletados na região Sudeste foram identificados como $P$. brasiliensis sensu stricto variedade S1a, divergindo da variedade encontrada na cidade de Ibiá, MG e identificada neste estudo como S1b. Mas, em dois isolados coletados na região Amazônica, a caracterização genotípica identificou uma mistura entre as variedades S1 (BAGAGLI et al., 2021). Isto sugere que a metodologia empregada neste estudo pode ter limitações para distinguir variedades S1a e S1b em isolados ambientais do gênero Paracoccidioides spp.

Os dados genotípicos obtidos neste estudo, podem contribuir para o conhecimento das espécies de Paracoccidioides spp. e mostram que o fator migração de humanos deverá ser considerado na determinação da biogeografia deste gênero.

\subsubsection{Relação entre os dados genotípicos e epidemiológicos de pacientes com PCM da região e cidade de Ribeirão Preto, SP, Brasil}

A maioria dos casos de PCM apresenta a forma crônica da doença (SHIKANAI-YASUDA et al., 2017). Além da origem geográfica e dados genotípicos a manifestação clínica da PCM é uma característica importante para compreender a patogenicidade de espécies do complexo $P$. brasiliensis e de $P$. lutzii. Em estudos recentes, foi avaliada a associação de agentes etiológicos ( $P$. brasiliensis sensu stricto (S1a e S1b), P. americana (PS2) e P. lutzii) nas regiões Sudeste e Centro - 
Oeste do Brasil com a respectiva forma clínica, tendo sido observado que a maioria dos pacientes tinham a forma crônica da doença, independente da espécie do gênero Paracoccidioides spp. (de MACEDO et al., 2019; HAHN et al., 2019; ARANTES et al., 2016). Neste estudo, a forma crônica da PCM foi observada na maioria dos casos atribuídos a $P$. brasiliensis sensu stricto (38 caracterizados como S1b e 5 como S1a) e nos pacientes infectados por $P$. americana (PS2) e $P$. lutzii. O paciente infectado por $P$. restrepiensis (PS3) tinha a forma sub-aguda da PCM, contudo em sua maioria os isolados clínicos PS3 correspondem a casos da forma crônica (PEREIRA et al., 2021; MATTOS et al., 2021). Não tem sido possível associar as espécies filogenéticas com a forma clínica da PCM, pois neste e em outros estudos a forma crônica da doença tem sido predominante em casos relacionados a diferentes genótipos de Paracoccidioides spp. (HAHN et al., 2019; SHIKANAI-YASUDA et al., 2017).

Aparentemente, o genótipo (espécies e variantes) não determina a forma clínica da doença, ou seja, o tipo de manifestação não é exclusiva de uma determinada espécie do gênero Paracoccidioides spp.

\subsection{Antigenicidade de exoantígenos miceliais de espécies do gênero Paracoccidioides spp.}

Além de métodos clássicos de identificação fúngica (morfológica) e técnicas de biologia molecular, os testes sorológicos tem sido um grande aliado para auxiliar no diagnóstico de PCM (DA SILVA et al., 2016). Em diferentes centros médicos do país, vários métodos de obtenção de antígenos e protocolos dos testes sorológicos vem sendo aplicados em soros de pacientes com suspeita de PCM (DA SILVA et al., 2016). Os antígenos mais utilizados, principalmente em pesquisa clínica, são 
aqueles obtidos através de proteínas extracelulares de leveduras, ou exocelulares, que provém de métodos de produção como "cell - free antígen" (CFA) e filtragem do meio de cultura (DA SILVA et al., 2016).

As frações proteicas extracelulares obtidas de células miceliais e mostradas por eletroforese SDS - PAGE, revelaram maior quantidade de bandas proteicas em cepas de referência do que em isolados clínicos (Figura 12A). Estas diferenças entre as cepas avaliadas neste estudo sugerem que cada organismo fúngico pode apresentar variações genéticas entre si e este fator poderia contribuir para produção de exoantígenos específicos para cada espécie do complexo $P$. brasiliensis e $P$. lutzii (DE ARRUDA GROSSKLAUS et al., 2016; BATISTA JR et al., 2010). Além disto, os exoantígenos miceliais com período de incubação por 60 dias produziram mais moléculas proteicas do que culturas com 30 dias de incubação, independente se a cultura com o fungo foi submetida a agitação ou estática.

Alguns estudos avaliaram frações proteicas de Paracoccidioides spp. obtidas a partir de proteínas extracelulares oriundas de leveduras, tanto isolados clínicos, como ambientais de diversas regiões do Brasil. Nestes trabalhos, a proteína mais avaliada constantemente em diferentes espécies do gênero Paracoccidioides spp., é a glicoproteína - 43 kDa, ou GP43, considerada como uma proteína específica (epítopo - antígeno) de espécies do complexo $P$. brasiliensis e eventualmente em $P$. lutzii com a finalidade de diagnóstico da PCM (CAMARGO et al., 2003; CISALPINO et al., 1996; MENDES - GIANINI et al., 1989; PUCCIA et al., 1986). Além de GP43, proteínas de tamanhos variados entre 60 e 70 kDa têm sido frequentemente observadas em isolados clínicos da espécie $P$. lutzii e podem ser considerados como potenciais antígenos específicos desta espécie (ASSOLINI et al., 2021; 
QUEIROZ - JUNIOR et al., 2014; GEGEMBAUER et al., 2014). Contudo, estas frações também são observadas no complexo $P$. brasiliensis.

Como mostrado em exoantígenos produzidos a partir de células leveduriformes de Paracoccidioides spp., a proteína GP43 também foi observada nas frações proteicas produzidas por células miceliais de cepas de referência e clínicas de espécies do complexo $P$. brasiliensis e $P$. lutzii avaliadas neste estudo. A ausência de expressão de GP43 foi observada na cepa de referência Pb01: P. lutzii - Cultura estática, 60 dias de incubação e cepa clínica HCRP191: P lutzii Agitação, 60 dias de incubação, que pertencem a mesma espécie (Tabela 5 e Figura 12B). A cepa clínica HCRP199: P. americana (PS2) - Agitação, 60 dias de incubação não apresentou expressão de GP43 (Tabela 5 e Figura 12B), ao contrário do observado na cepa de referência EPM194 - Pbdog: P. americana (PS2) Cultura estática, 30 dias, pertencente a mesma espécie que apresentou a molécula proteica de tamanho $43 \mathrm{kDa}$. Estas características de presença ou não de moléculas antigênicas, principalmente de GP43, já foram descritos em estudos prévios onde foram utilizados exoantígenos produzidos por células leveduriformes de diferentes espécies de Paracoccidioides spp.. Independentemente do método utilizado para a obtenção de exoantígenos, foi observada a presença de GP43 em diferentes intensidades de expressão em isolados clínicos e ambientais de espécies do complexo $P$. brasiliensis e $P$. lutzii (DE ARRUDA GROSSKLAUS et al., 2016; GEGEMBAUER et al., 2014; MACHADO et al., 2013; BERZAGHI et al., 2005; CAMARGO et al., 2003). Portanto, a presença ou não de GP43 em exoantígenos miceliais produzidos por cepas pertencentes as espécies do complexo $P$. brasiliensis e $P$. lutzii sugere que o tipo morfológico e a metodologia empregada para obter 
estas moléculas antigênicas são considerados fatores importantes para a produção de determinadas proteínas.

$\mathrm{Na}$ avaliação dos exoantigenos miceliais deste estudo, além de GP43, foram observados proteínas de tamanho aproximado de 60 e 70 kDa que são considerados possíveis moléculas antigênicas reconhecidos por soros de pacientes com PCM. As cepas de referência e clínica pertencentes a espécie $P$. lutzii, produziram em alta expressão possíveis moléculas antigênicas de tamanho aproximado de 60 e 70 kDa (Tabela 5 e Figura 12B). Em estudos analisando perfil antigênico de exoantigenos produzidos de células leveduriformes de isolados clínicos de $P$. lutzii foram observadas frações proteicas de tamanho 60 e 70 kDa e a ausência ou baixa expressão de GP43 (DE ARRUDA GROSSKLAUS et al., 2016; GEGEMBAUER et al., 2014; QUEIROZ - JUNIOR et al., 2014; MACHADO et al., 2013). Foi observado nestes estudos que as cepas clínicas de espécies do complexo $P$. brasiliensis não produziram proteínas de 60 e 70 kDa, sugerindo que estas possam ser exclusivas da espécie P. lutzii (DE ARRUDA GROSSKLAUS et al., 2016; GEGEMBAUER et al., 2014; QUEIROZ - JUNIOR et al., 2014). Tais achados não foram confirmados no presente estudo, pois $P$. americana (PS2) (EPM194 Pbdog) e HCRP171: P. brasiliensis sensu stricto (S1a), do complexo P. brasiliensis, produziram fração proteica com 60 kDa (DE ARRUDA GROSSKLAUS et al., 2016; GEGEMBAUER et al., 2014; QUEIROZ - JUNIOR et al., 2014). Assolini et al. (2021) observaram a baixa expressão de proteína de tamanho 70 kDa em exoantígeno produzido por células leveduriformes em cepa da espécie $P$. americana (PS2) e sua ausência em $P$. restrepiensis (PS3), resultados similares aos do presente estudo (Tabela 5 e Figura 12B). Estes últimos estudos e resultados aqui apresentados mostram que exoantígenos miceliais contém frações proteicas, como 
GP43, 60 e 70 kDa, importantes para o diagnóstico sorológico da PCM, as quais podem ser expressas. Estes resultados mostram que exoantígenos miceliais avaliados nestes estudo produzem frações proteicas e que contém proteínas consideradas possíveis antígenos importantes para o diagnóstico de PCM como a GP43, 60 e $70 \mathrm{kDa}$, estas podendo ser expressas de maneiras diferentes para cada espécie do gênero Paracoccidioides spp. Estas características observadas podem ser explicadas por possíveis alterações nos níveis de expressão proteica, fatores pós transcrição, alteração e variação das formas proteicas, condições de cultivo, variação genética e também os diferentes métodos utilizados para obter estes antígenos (DA SILVA et al., 2016; MACHADO et al., 2013; BERZAGHI et al., 2005).

Para avaliar a reatividade de soros de pacientes cuja espécie de Paracoccidioides spp. foi identificada pelos métodos de biologia molecular empregado neste estudo, utilizamos as técnicas imunodifusão dupla (IDD) e contraimunoeletroforese $(\mathrm{CIE})$ que nos auxiliaram a responder questionamento quanto a diferenças que possam existir em exoantígenos de diferentes espécies do complexo $P$. brasiliensis e $P$. lutzii.

Nos testes utilizando a técnica IDD observamos que os exoantígenos miceliais das espécies que pertencem ao complexo $P$. brasiliensis tiveram $100 \%$ de reatividade frente aos soros testados (Tabela 7). Exoantígenos produzidos por $P$. lutzii (Pb01 e HCRP191) não obtiveram o mesmo desempenho quanto à reação frente a estes soros, comparando com os antígenos do complexo $P$. brasiliensis (Tabela 7). Para os soros cujos isolados fúngicos foram identificados como pertencentes as espécies do complexo $P$. brasiliensis, os exoantígenos de $P$. lutzii (Pb01 e HCRP191) obtiveram reação positiva de 86,7\% e 53,3\%, respectivamente (Tabela 7). Além das reações antígeno - anticorpo, foi observada a identidade das 
linhas de precipitação entre os diferentes exoantígenos frente aos soros avaliados neste estudo. Os imunoprecipitados relacionados com antígenos das espécies do complexo $P$. brasiliensis formaram bandas interligadas frente aos soros dos pacientes correspondentes, sugerindo que as frações moleculares possam ser idênticas. Conforme estudos prévios demonstraram, a banda mais intensa e frequentemente formada entre os antígenos do complexo $P$. brasiliensis e soros de pacientes infectados por estas espécies é decorrente da ligação de anticorpos à GP43 (DE ARRUDA GROSSKLAUS et al., 2016; GEGEMBAUER et al., 2014; MACHADO et al., 2013; BERZAGHI et al., 2005; CAMARGO et al., 2003; SILVA VERGARA et al., 1998). Quanto aos exoantígenos de $P$. lutzii, tanto a cepa de referência quanto a clínica, apresentaram uma linha de precipitação não idêntica ou com identidade parcial frente a alguns pacientes infectados por espécies do complexo $P$. brasiliensis. A diferença entre as reações antigênicas e a não identidade das linhas de precipitação comparadas entre as espécies do complexo $P$. brasiliensis e $P$. lutzii sugere que há componentes antigênicos presentes em $P$. lutzii que podem ser específicos e exclusivos para esta espécie (GEGEMBAUER et al., 2014). Embora a imunoprecipitação no gel tenha sido distinta, observamos que exoantígenos $P$. lutzii reagiram com alguns soros de pacientes cujos isolados fúngicos pertencem a espécies do complexo $P$. brasiliensis. Este resultado não condiz com o relato de Gegembauer et al. (2014) onde foi verificado que exoantígenos $P$. lutzii obtidos de células leveduriformes não reagem com soros de pacientes que foram infectados por espécies do complexo $P$. brasiliensis.

Comparando as técnicas sorológicas utilizadas neste estudo, imunodifusão dupla (IDD) e countraimunoelétroforese (CIE), observamos que há diferenças de sensibilidade quando empregados exoantígenos miceliais produzidos a partir das 
cepas de referência e clínica pertencentes a espécie $P$. lutzii (Tabela 9). Exoantígenos produzidos de cepas do complexo $P$. brasiliensis, obtiveram sensibilidade de $100 \%$ frente aos soros avaliados neste estudo em ambas as técnicas. Porém, para exoantígenos $P$. lutzii a sensibilidade em IDD foi maior em relação à CIE (Tabela 9). Este resultado sugere que além da variação genética e dos diferentes componentes antigênicos dos exoantígenos miceliais das espécies do gênero Paracoccidioides spp. a características dos testes sorológicos empregados neste estudo foi um fator na avaliação de antigenicidade. Bellissimo - Rodrigues et al. (2010) avaliaram soros de pacientes HIV - positivos com PCM, comparando as técnicas IDD e CIE. Foi observado que a sensibilidade de IDD é baixa comparando com CIE, confirmando a maior sensibilidade deste último método (DA SILVA et al., 2016; BELLISSIMO - RODRIGUES et al., 2010). Na CIE só participam da formação dos imunoprecipitados antígenos com carga elétrica negativa (SIQUEIRA \& LACAZ, 1991), isto e a diferença na composição antigênica poderiam explicar a menor reatividade de exoantígenos miceliais avaliados neste estudo utilizando esta técnica.

Exoantígenos miceliais podem ser uma alternativa de produção de moléculas antigênicas, verificando-se que reagem com soros de pacientes com PCM utilizando diferentes técnicas sorológicas em gel para a detecção de anticorpos anti Paracoccidioides. 


\section{CONCLUSÃO}

1. Em sua maioria os isolados clínicos de Paracoccidioides spp. submetidos a tipagem molecular foram identificados como a espécie $P$. brasiliensis sensu stricto (variantes S1a e S1b), mostrando sua predominância no nordeste do Estado de São Paulo e no sudoeste de Minas Gerais como causa de PCM humana.

2. O isolamento de P. restrepiensis (PS3) em caso autóctone de PCM da região de Ribeirão Preto, SP revela certa diversidade genética de Paracoccidioides spp. nesta área geográfica.

3. $\mathrm{O}$ isolamento de $P$. americana (PS2) e de $P$. lutzii de pacientes com longa permanência em outras áreas endêmicas do Brasil mostra a importância do histórico epidemiológico dos doentes de PCM na determinação da distribuição geográfica das espécies de Paracoccidioides spp.

4. Paracoccidioides spp. isolados de fontes ambientais de lbiá, MG, foram identificados como $P$. brasiliensis sensu stricto (S1b), similarmente aos isolados de doentes de PCM residentes em área próxima ao sudoeste do Estado de Minas Gerais.

5. Não se encontrou associação das diferentes espécies e variantes identificadas com as formas clínicas aguda - subaguda ou crônica da PCM. 
6. Tal como as leveduras, o micélio de espécies do complexo $P$. brasiliensis e $P$. lutzii é fonte de moléculas antigênicas para testes sorológicos de imunoprecipitação em gel.

7. Apesar de variabilidade na presença e na quantidade de frações proteicas, os exoantígenos das espécies do complexo $P$. brasiliensis reagiram uniformemente com soros de pacientes infectados por diferentes espécies deste complexo, formando bandas de imunocomplexos idênticas entre si e sugerindo a presença de uma molécula antigênica comum secretada ou excretada in vivo.

8. A menor reatividade e a não - identidade das bandas de imunoprecipitados na reação em gel dos soros de pacientes com PCM com exoantígenos de $P$. lutzii, comparativamente a exoantígenos de espécies do complexo $P$. brasiliensis, sugerem que a antigenicidade de $P$. lutzii depende de molécula diferente daquela envolvida nas reações imunes do complexo $P$. brasiliensis, provavelmente por diferença fenotípica metabólica entre as espécies. 


\section{REFERÊNCIAS BIBLIOGRÁFICAS}

1. ALTSCHUL, S. F.; GISH, W.; MILLER, W.; MYERS, E. W.; LIPMAN, D. J. Basic local alignment search tool. J Mol Biol, 215, n. 3, p. 403-410, 1990.

2. ARANTES, T. D.; THEODORO, R. C.; DA GRACA MACORIS, S. A.; BAGAGLI, E. Detection of Paracoccidioides spp. in environmental aerosol samples. Med Mycol, 51, n. 1, p. 83-92, 2013.

3. ARANTES, T. D.; THEODORO, R. C.; TEIXEIRA MDE, M.; BOSCO SDE, M.; BAGAGLI, E. Environmental Mapping of Paracoccidioides spp. in Brazil Reveals New Clues into Genetic Diversity, Biogeography and Wild Host Association. PLoS Negl Trop Dis, 10, n. 4, p. e0004606, 2016.

4. ASSOLINI, J. P.; LENHARD-VIDAL, A.; CARLA, S. d. O.; TANO, Z. N.; SANO, A. et al. Distinct Pattern of Paracoccidioides lutzii, P. restrepiensis and $P$. americana Antigens Recognized by $\mathrm{IgE}$ in Human Paracoccidioidomycosis. Current Microbiology, p. 1-7, 2021.

5. BAGAGLI, E.; MATUTE, D. R.; GARCES, H. G.; TENORIO, B. G.; GARCES, A. G. et al. Paracoccidioides brasiliensis Isolated from Nine-Banded Armadillos (Dasypus novemcinctus) Reveal Population Structure and Admixture in the Amazon Basin. J Fungi (Basel), 7, n. 1, 2021.

6. BATISTA JR, J.; DE CAMARGO, Z. P.; FERNANDES, G. F.; VICENTINI, A. P.; FONTES, C. J. F. et al. Is the geographical origin of a Paracoccidioides brasiliensis isolate important for antigen production for regional diagnosis of paracoccidioidomycosis? Mycoses, 53, n. 2, p. 176-180, 2010.

7. BELLISSIMO-RODRIGUES, F.; BOLLELA, V. R.; DA FONSECA, B. A. L.; MARTINEZ, R. Endemic paracoccidioidomycosis: relationship between clinical presentation and patients' demographic features. Sabouraudia, 51, n. 3, p. 313-318, 2013.

8. BELLISSIMO-RODRIGUES, F.; MACHADO, A. A.; MARTINEZ, R. Paracoccidioidomycosis epidemiological features of a 1,000-cases series from a hyperendemic area on the southeast of Brazil. Am J Trop Med Hyg, 85, n. 3, p. 546550, 2011.

9. BELLISSIMO-RODRIGUES, F.; VITALI, L. H.; MARTINEZ, R. Serological diagnosis of paracoccidioidomycosis in HIV-coinfected patients. Mem Inst Oswaldo Cruz, 105, n. 7, p. 904-907, 2010. 
10. BERZAGHI, R.; SILVA, S. H. M. d.; CAMARGO, Z. P. d. Variable gp43 Secretion by Paracoccidioides brasiliensis Clones Obtained by Two Different Culture Methods. Journal of Clinical Microbiology, 43, n. 1, p. 491-493, 2005.

11. BRADFORD, M. M. A rapid and sensitive method for the quantitation of microgram quantities of protein utilizing the principle of protein-dye binding. Anal Biochem, 72, p. 248-254, 1976.

12. CALCAGNO, A. M.; NINO-VEGA, G.; SAN-BLAS, F.; SAN-BLAS, G. Geographic discrimination of Paracoccidioides brasiliensis strains by randomly amplified polymorphic DNA analysis. J Clin Microbiol, 36, n. 6, p. 1733-1736, 1998.

13. CAMARGO, Z.; RODRIGUES, A. Paracoccidioides complex. Pocket Guide to Mycological Diagnosis, 78, p. 125-134, 2019.

14. CAMARGO, Z. P.; BERZAGHI, R.; AMARAL, C. C.; SILVA, S. H. Simplified method for producing Paracoccidioides brasiliensis exoantigens for use in immunodiffusion tests. Med Mycol, 41, n. 6, p. 539-542, 2003.

15. CARRERO, L. L.; NINO-VEGA, G.; TEIXEIRA, M. M.; CARVALHO, M. J. A.; SOARES, C. M. et al. New Paracoccidioides brasiliensis isolate reveals unexpected genomic variability in this human pathogen. Fungal Genetics and Biology, 45, n. 5, p. 605-612, 2008.

16. CASOTTO, M. Characterization of the cellular antigens of Paracoccidioides brasiliensis yeast form. Journal of Clinical Microbiology, 28, n. 6, p. 1188-1193, 1990.

17. CISALPINO, P. S.; PUCCIA, R.; YAMAUCHI, L. M.; CANO, M. I.; DA SILVEIRA, J. F. et al. Cloning, characterization, and epitope expression of the major diagnostic antigen of Paracoccidioides brasiliensis. J Biol Chem, 271, n. 8, p. 4553$4560,1996$.

18. COCIO, T. A. Caracterização funcional do gene codificador de uma proteína com peptídeo sinal, masA, de Aspergillus fumigatus. (Mestrado) -, Faculdade de Ciências Farmacêuticas de Ribeirão Preto - Universidade de São Paulo. 2016.

19. COCIO, T. A.; MARTINEZ, R. Serological diagnosis of paracoccidioidomycosis using a Paracoccidioides spp. comercial antigen and the counterimmunoelectrophoresis method. The Brazilian Journal of Infectious Diseases, p. 101607, 2021. 
20. DA SILVA, J. d. F.; DE OLIVEIRA, H. C.; MARCOS, C. M.; ASSATO, P. A.; FUSCO-ALMEIDA, A. M. et al. Advances and challenges in paracoccidioidomycosis serology caused by Paracoccidioides species complex: an update. Diagnostic Microbiology and Infectious Disease, 84, n. 1, p. 87-94, 2016.

21. DE ARRUDA GROSSKLAUS, D.; TAKAHARA, D. T.; KRUGER, C. S.; GONZAGA, A. M.; DE CAMARGO, Z. P. et al. Profile of exoantigens from clinical isolates of Paracoccidioides lutzii IN Mato Grosso, Brazil. Revista de Patologia Tropical/Journal of Tropical Pathology, 45, n. 3, p. 265-272, 2016.

22. DE CAMARGO, Z.; UNTERKIRCHER, C.; CAMPOY, S. P.; TRAVASSOS, L. R. Production of Paracoccidioides brasiliensis exoantigens for immunodiffusion tests. Journal of Clinical Microbiology, 26, n. 10, p. 2147-2151, 1988.

23. DE CAMARGO, Z. P. Serology of paracoccidioidomycosis. Mycopathologia, 165 , n. 4, p. 289, 2008.

24. DE FARIAS, M. R.; CONDAS, L. A.; RIBEIRO, M. G.; BOSCO SDE, M.; MURO, M. D. et al. Paracoccidioidomycosis in a dog: case report of generalized lymphadenomegaly. Mycopathologia, 172, n. 2, p. 147-152, 2011.

25. DE MACEDO, P. M.; ALMEIDA-PAES, R.; DE MEDEIROS MUNIZ, M.; OLIVEIRA, M. M. E.; ZANCOPÉ-OLIVEIRA, R. M. et al. Paracoccidioides brasiliensis PS2: First Autochthonous Paracoccidioidomycosis Case Report in Rio de Janeiro, Brazil, and Literature Review. Mycopathologia, 181, n. 9, p. 701-708, 2016.

26. DE MACEDO, P. M.; TEIXEIRA, M. M.; BARKER, B. M.; ZANCOPEOLIVEIRA, R. M.; ALMEIDA-PAES, R. et al. Clinical features and genetic background of the sympatric species Paracoccidioides brasiliensis and Paracoccidioides americana. PLoS Negl Trop Dis, 13, n. 4, p. e0007309, 2019.

27. FAVA, N. Quantitative Studies on the Fixation of Complement in South American Blastomycosis, with Polysaccharide Antigen. Arquivos de Cirurg. Clin. e Exper., 18, n. 5/6, p. 197-254, 1955.

28. FAVA NETTO, C. Durabilidade do antigeno polissacarideo de Paracoccidioides brasiliensis. Rev. microbiol, p. 27-32, 1984.

29. GegembaueR, G.; ARAUJO, L. M.; PEREIRA, E. F.; RODRIGUES, A. M.; PANIAGO, A. M. et al. Serology of paracoccidioidomycosis due to Paracoccidioides lutzii. PLoS Negl Trop Dis, 8, n. 7, p. e2986, 2014. 
30. GONZALEZ, A.; HERNANDEZ, O. New insights into a complex fungal pathogen: the case of Paracoccidioides spp. Yeast, 33, n. 4, p. 113-128, 2016.

31. HAHN, R. C.; RODRIGUES, A. M.; DELLA TERRA, P. P.; NERY, A. F.; HOFFMANN-SANTOS, $H$. D. et al. Clinical and epidemiological features of paracoccidioidomycosis due to Paracoccidioides lutzii. PLoS Negl Trop Dis, 13, n. 6, p. e0007437, 2019.

32. HRYCYK, M. F.; GARCIA GARCES, H.; BOSCO, S. M. G.; DE OLIVEIRA, S. L.; MARQUES, S. A. et al. Ecology of Paracoccidioides brasiliensis, $P$. lutzii and related species: infection in armadillos, soil occurrence and mycological aspects. Med Mycol, 56, n. 8, p. 950-962, 2018.

33. KASUGA, T.; WHITE, T. J.; TAYLOR, J. W. Estimation of nucleotide substitution rates in Eurotiomycete fungi. Mol Biol Evol, 19, n. 12, p. 2318-2324, 2002.

34. LACAZ C. DA, S.; VIDAL, M. S.; HEINS-VACCARI, E. M.; DE MELO, N. T.; DEL NEGRO, G. M. et al. Paracoccidioides brasiliensis. A mycologic and immunochemical study of two strains. Rev Inst Med Trop Sao Paulo, 41, n. 2, p. 7986, 1999.

35. LENHARD-VIDAL, A.; ASSOLINI, J.; ONO, M.; BREDT, C.; SANO, A. et al. Paracoccidioides brasiliensis and $P$. lutzii antigens elicit different serum IgG responses in chronic paracoccidioidomycosis. Mycopathologia, 176, n. 5-6, p. 345352, 2013.

36. MACHADO, G. C.; MORIS, D. V.; ARANTES, T. D.; SILVA, L. R. F.; THEODORO, R. C. et al. Cryptic species of Paracoccidioides brasiliensis: impact on paracoccidioidomycosis immunodiagnosis. Memórias do Instituto Oswaldo Cruz, 108, n. 5, p. 637-643, 2013.

37. MARQUES-DA-SILVA, S. H.; RODRIGUES, A. M.; DE HOOG, G. S.; SILVEIRA-GOMES, F.; CAMARGO, Z. P. Occurrence of Paracoccidioides lutzii in the Amazon region: description of two cases. Am J Trop Med Hyg, 87, n. 4, p. 710-714, 2012.

38. MARTINEZ, R. New Trends in Paracoccidioidomycosis Epidemiology. J Fungi (Basel), 3, n. 1, p.: E1, 2017.

39. MATOS, W. B.; DOS SANTOS, G. M.; SILVA, V. E.; ROSARIO GONCALVES, E. G.; SILVA, A. R. Paracoccidioidomycosis in the state of Maranhao, Brazil: 
geographical and clinical aspects. Rev Soc Bras Med Trop, 45, n. 3, p. 385-389, 2012.

40. MATTOS, K.; COCIO, T. A.; CHAVES, E. G. A.; BORGES, C. L.; VENTURINI, J. et al. An update on the occurrence of Paracoccidioides species in the Midwest region, Brazil: Molecular epidemiology, clinical aspects and serological profile of patients from Mato Grosso do Sul State. PLoS Negl Trop Dis, 15, n. 4, p. e0009317, 2021.

41. MATUTE, D. R.; MCEWEN, J. G.; PUCCIA, R.; MONTES, B. A.; SAN-BLAS, G. et al. Cryptic speciation and recombination in the fungus Paracoccidioides brasiliensis as revealed by gene genealogies. Mol Biol Evol, 23, n. 1, p. 65-73, 2006.

42. MENDES-GIANNINI, M. J.; BUENO, J. P.; SHIKANAI-YASUDA, M. A.; FERREIRA, A. W.; MASUDA, A. Detection of the 43,000-molecular-weight glycoprotein in sera of patients with paracoccidioidomycosis. Journal of Clinical Microbiology, 27, n. 12, p. 2842-2845, 1989.

43. MUÑOZ, J. F.; FARRER, R. A.; DESJARDINS, C. A.; GALLO, J. E.; SYKES, $S$. et al. Genome diversity, recombination, and virulence across the major lineages of Paracoccidioides. mSphere, 1, n. 5, 2016.

44. NINO-VEGA, G. A.; CALCAGNO, A. M.; SAN-BLAS, G.; SAN-BLAS, F.; GOODAY, G. W. et al. RFLP analysis reveals marked geographical isolation between strains of Paracoccidioides brasiliensis. Med Mycol, 38, n. 6, p. 437-441, 2000.

45. PEREIRA, B. A. S.; AMORIM, B. C.; MARÇON, C.; SILVA, J. d. F.; CAVALCANTE, R. d. S. et al. Patogenicidade e imunogenicidade de isolados clínicos do gênero Paracoccidioides e sua associação com a gravidade dos pacientes. The Brazilian Journal of Infectious Diseases, 25, p. 101437, 2021.

46. PEREIRA, E. F.; GeGeMBAUER, G.; CHANG, M. R.; CAMARGO, Z. P. d.; NUNES, T. F. et al. Comparison of clinico-epidemiological and radiological features in paracoccidioidomycosis patients regarding serological classification using antigens from Paracoccidioides brasiliensis complex and Paracoccidioides lutzii. PLoS neglected tropical diseases, 14, n. 8, p. e0008485, 2020.

47. PINHEIRO, B. G.; HAHN, R. C.; CAMARGO, Z. P. d.; RODRIGUES, A. M. Molecular Tools for Detection and Identification of Paracoccidioides Species: Current Status and Future Perspectives. Journal of Fungi, 6, n. 4, p. 293, 2020. 
48. PUCCIA, R.; SCHENKMAN, S.; GORIN, P. A.; TRAVASSOS, L. R. Exocellular components of Paracoccidioides brasiliensis: identification of a specific antigen. Infection and Immunity, 53, n. 1, p. 199-206, 1986.

49. QUEIROZ JUNIOR, L. d. P.; DE CAMARGO, Z. P.; TADANO, T.; RODRIGUES, A. M.; TAKARARA, D. T. et al. Serological and antigenic profiles of clinical isolates of Paracoccidioides spp. from Central Western Brazil. Mycoses, 57, n. 8, p. 466-472, 2014.

50. RAMOS, E. S. M.; SARAIVA LDO, E. Paracoccidioidomycosis. Dermatol Clin, 26, n. 2, p. 257-269, vii, 2008.

51. RESTREPO-MORENO, A.; SCHNEIDAU, J. D., Jr. Nature of the skin-reactive principle in culture filtrates prepared from Paracoccidioides brasiliensis. $\mathbf{J}$ Bacteriol, 93, n. 6, p. 1741-1748, 1967.

52. RESTREPO, A.; CANO, L. E.; GONZALEZ, A. The power of the small: the example of Paracoccidioides brasiliensis conidia. Revista do Instituto de Medicina Tropical de São Paulo, 57, p. 5-10, 2015.

53. RESTREPO, A.; JIMENEZ, B. E. Growth of Paracoccidioides brasiliensis yeast phase in a chemically defined culture medium. J Clin Microbiol, 12, n. 2, p. 279-281, 1980.

54. ROBERTO, T. N.; RODRIGUES, A. M.; HAHN, R. C.; DE CAMARGO, Z. P. Identifying Paracoccidioides phylogenetic species by PCR-RFLP of the alpha-tubulin gene. Med Mycol, 54, n. 3, p. 240-247, 2016.

55. SAIKI, R. K.; SCHARF, S.; FALOONA, F.; MULLIS, K. B.; HORN, G. T. et al. Enzymatic amplification of beta-globin genomic sequences and restriction site analysis for diagnosis of sickle cell anemia. Science, 230, n. 4732, p. 1350-1354, 1985.

56. SAMBROOK, J.; RUSSELL, D. W. Molecular Cloning: a Laboratory Manual Fourth edition ed Cold Spring Harbor. New York: Cold Spring Habour Laboratory Press 2001.

57. SAN-BLAS, G.; SAN-BLAS, F. Antigenic structure of Paracoccidioides brasiliensis. Immunol Ser, 47, p. 171-192, 1989. 
58. SHIKANAI-YASUDA, M. A.; MENDES, R. P.; COLOMBO, A. L.; QUEIROZTELLES, F.; KONO, A. S. G. et al. Brazilian guidelines for the clinical management of paracoccidioidomycosis. Rev Soc Bras Med Trop, 50, n. 5, p. 715-740, 2017.

59. SHIKANAI-YASUDA, M. A.; MENDES, R. P.; COLOMBO, A. L.; TELLES, F. Q.; KONO, A. et al. [Brazilian guidelines for the clinical management of paracoccidioidomycosis]. Epidemiol Serv Saude, 27, n. spe, p. e0500001, 2018.

60. SILVA-VERGARA, M. L.; MARTINEZ, R.; CAMARGO, Z. P.; MALTA, M. H.; MAFFEI, C. M. et al. Isolation of Paracoccidioides brasiliensis from armadillos (Dasypus novemcinctus) in an area where the fungus was recently isolated from soil. Med Mycol, 38, n. 3, p. 193-199, 2000.

61. SILVA-VERGARA, M. L.; MARTINEZ, R.; CHADU, A.; MADEIRA, M.; FREITAS-SILVA, G. et al. Isolation of a Paracoccidioides brasiliensis strain from the soil of a coffee plantation in Ibia, State of Minas Gerais, Brazil. Med Mycol, 36, n. 1, p. 37-42, 1998.

62. SIQUEIRA, A.; LACAZ, C. Serologic characterization of Paracoccidioides brasiliensis E2 antigen. Brazilian journal of Medical and Biological Research, 24, n. 8, p. 807-813, 1991.

63. TAKAYAMA, A.; ITANO, E. N.; SANO, A.; ONO, M. A.; KAMEI, K. An atypical Paracoccidioides brasiliensis clinical isolate based on multiple gene analysis. Med Mycol, 48, n. 1, p. 64-72, 2010.

64. TAMURA, K.; STECHER, G.; PETERSON, D.; FILIPSKI, A.; KUMAR, S. MEGA6: Molecular Evolutionary Genetics Analysis version 6.0. Mol Biol Evol, 30, n. 12, p. 2725-2729, 2013.

65. TEIXEIRA, M. M.; CATTANA, M. E.; MATUTE, D. R.; MUNOZ, J. F.; ARECHAVALA, A. et al. Genomic diversity of the human pathogen Paracoccidioides across the South American continent. Fungal Genet Biol, 140, p. 103395, 2020.

66. TEIXEIRA, M. M.; THEODORO, R. C.; DE CARVALHO, M. J.; FERNANDES, L.; PAES, H. C. et al. Phylogenetic analysis reveals a high level of speciation in the Paracoccidioides genus. Mol Phylogenet Evol, 52, n. 2, p. 273-283, 2009.

67. TEIXEIRA, M. M.; THEODORO, R. C.; NINO-VEGA, G.; BAGAGLI, E.; FELIPE, M. S. Paracoccidioides species complex: ecology, phylogeny, sexual reproduction, and virulence. PLoS Pathog, 10, n. 10, p. e1004397, 2014a. 
68. TEIXEIRA MDE, M.; THEODORO, R. C.; OLIVEIRA, F. F.; MACHADO, G. C.; HAHN, R. C. et al. Paracoccidioides lutzii sp. nov.: biological and clinical implications. Med Mycol, 52, n. 1, p. 19-28, 2014b.

69. THEODORO, R. C.; TEIXEIRA MDE, M.; FELIPE, M. S.; PADUAN KDOS, S.; RIBOLLA, P. M. et al. Genus Paracoccidioides: Species recognition and biogeographic aspects. PLoS One, 7, n. 5, p. e37694, 2012.

70. TURISSINI, D. A.; GOMEZ, O. M.; TEIXEIRA, M. M.; MCEWEN, J. G.; MATUTE, D. R. Species boundaries in the human pathogen Paracoccidioides. Fungal Genet Biol, 106, p. 9-25, 2017.

71. VAN BURIK, J. A.; SCHRECKHISE, R. W.; WHITE, T. C.; BOWDEN, R. A.; MYERSON, D. Comparison of six extraction techniques for isolation of DNA from filamentous fungi. Med Mycol, 36, n. 5, p. 299-303, 1998.

72. VIDAL, M. S. M.; DEL NEGRO, G. M. B.; VICENTINI, A. P.; SVIDZINSKI, T. I. E.; MENDES-GIANNINI, M. J. et al. Serological diagnosis of paracoccidioidomycosis: high rate of inter-laboratorial variability among medical mycology reference centers. PLoS Negl Trop Dis, 8, n. 9, p. e3174, 2014.

73. VIEIRA GDE, D.; ALVES TDA, C.; LIMA, S. M.; CAMARGO, L. M.; SOUSA, C. M. Paracoccidioidomycosis in a western Brazilian Amazon State: clinicalepidemiologic profile and spatial distribution of the disease. Rev Soc Bras Med Trop, 47 , n. 1, p. 63-68, 2014.

74. WESSELINGH, F.; SALO, J. A Miocene perspective on the evolution of the Amazonian biota. Scripta Geologica, 133, p. 439-458, 2006.

75. WHITE, T. J.; BRUNS, T.; LEE, S.; TAYLOR, J. Amplification and direct sequencing of fungal ribosomal RNA genes for phylogenetics. PCR protocols: a guide to methods and applications, 18, n. 1, p. 315-322, 1990.

76. YARZABAL, L. Composición antigénica de Paracoccidioides brasiliensis. Paracoccidioidomicose. S. A. Sarvier, EDUSP, Sào Paulo, Brazil, p. 59-67, 1982. 
9. ANEXOS 


\section{ANEXOS}

Anexo 1 - Tabela Suplementar 1. Isolado, Amostra, Idade, Sexo, Forma clínica, origem geográfica, ano do isolamento fúngico e genótipo dos isolados clínicos avaliados neste estudo.

\begin{tabular}{|c|c|c|c|c|c|c|c|}
\hline Isolado & Amostra & Idade & Sexo & Forma Clínica & Origem Geográfica & Ano de Isolamento fúngico & Genótipo \\
\hline HCRP 001 & Linfonodo & 21 & $M$ & Aguda & Monte Santo de Minas - MG & 1975 & $P$. brasiliensis sensu stricto $\mathrm{S} 1 \mathrm{~b}$ \\
\hline HCRP 002 & Linfonodo & 27 & M & Crônica & Ribeirão Preto - SP & 1988 & P. brasiliensis sensu stricto $\mathrm{S} 1 \mathrm{~b}$ \\
\hline HCRP 003 & Linfonodo & 27 & M & Sub aguda & Guaíra - SP & 1992 & P. brasiliensis sensu stricto $\mathrm{S} 1 \mathrm{~b}$ \\
\hline HCRP 004 & Escarro & 54 & M & Crônica & Serrana - SP & 1995 & P. brasiliensis sensu stricto $\mathrm{S} 1 \mathrm{~b}$ \\
\hline HCRP 005 & Linfonodo & 31 & M & Sub aguda & Jaboticabal - SP & 1995 & P. brasiliensis sensu stricto $\mathrm{S} 1 \mathrm{~b}$ \\
\hline HCRP 006 & Desconhecido & - & - & Crônica & Ribeirão Preto - SP & 1996 & P. brasiliensis sensu stricto $\mathrm{S} 1 \mathrm{~b}$ \\
\hline HCRP 007 & Linfonodo & 47 & M & Sub aguda & Santa Rita de Cássia - MG & 1996 & P. brasiliensis sensu stricto $\mathrm{S} 1 \mathrm{~b}$ \\
\hline HCRP 008 & Desconhecido & 45 & M & Crônica & Monte Santo de Minas - MG & 1996 & P. brasiliensis sensu stricto $\mathrm{S} 1 \mathrm{~b}$ \\
\hline HCRP 009 & Linfonodo & 41 & M & Crônica & Ibitinga - SP & 1996 & P. brasiliensis sensu stricto $\mathrm{S} 1 \mathrm{~b}$ \\
\hline HCRP 054 & Biópsia de pele & 40 & M & Crônica & Cravinhos - SP & 1999 & P. brasiliensis sensu stricto $\mathrm{S} 1 \mathrm{a}$ \\
\hline HCRP 055 & Linfonodo & 15 & M & Sub aguda & Barrinha - SP & 1999 & P. brasiliensis sensu stricto $\mathrm{S} 1 \mathrm{~b}$ \\
\hline HCRP 056 & Linfonodo & 15 & M & Sub aguda & Ribeirão Preto - SP & 1999 & P. brasiliensis sensu stricto $\mathrm{S} 1 \mathrm{~b}$ \\
\hline HCRP 063 & Linfonodo & 39 & M & Crônica & Imperatriz - MA & 2000 & P. brasiliensis sensu stricto $\mathrm{S} 1 \mathrm{~b}$ \\
\hline HCRP 077 & Mucosa & 75 & M & Sub aguda & São João Batista da Gloria - MG & 2001 & P. brasiliensis sensu stricto $\mathrm{S} 1 \mathrm{~b}$ \\
\hline HCRP 078 & Escarro & 30 & M & Aguda & Ribeirão Preto - SP & 2002 & P. brasiliensis sensu stricto $\mathrm{S} 1 \mathrm{~b}$ \\
\hline HCRP 080 & Biópsia de pele & 36 & M & Sub aguda & Barrinha - SP & 2001 & P. brasiliensis sensu stricto $\mathrm{S} 1 \mathrm{a}$ \\
\hline HCRP 105 & Biópsia de pele & 47 & M & Crônica & Porto Ferreira - SP & 2004 & P. brasiliensis sensu stricto $\mathrm{S} 1 \mathrm{~b}$ \\
\hline HCRP 130 & Broncoalveolar & 50 & M & Crônica & Jaboticabal - SP & 2007 & P. brasiliensis sensu stricto $\mathrm{S} 1 \mathrm{~b}$ \\
\hline HCRP 149 & Biópsia de pele & 53 & M & Crônica & Morro Agudo - SP & 2010 & P. brasiliensis sensu stricto $\mathrm{S} 1 \mathrm{a}$ \\
\hline HCRP 154 & Biópsia de pele & 11 & $\mathrm{~F}$ & Sub aguda & Pitangueiras - SP & 2011 & P. brasiliensis sensu stricto $\mathrm{S} 1 \mathrm{~b}$ \\
\hline
\end{tabular}

Autoria: Fonte Própria. 
Anexo 1 - Tabela Suplementar 1. Isolado, Amostra, Idade, Sexo, Forma clínica, origem geográfica, ano do isolamento fúngico e genótipo dos isolados clínicos avaliados neste estudo.

\begin{tabular}{|c|c|c|c|c|c|c|c|}
\hline Isolado & Amostra & ldade & Sexo & Forma Clínica & Origem Geográfica & Ano de Isolamento fúngico & Genótipo \\
\hline HCRP 157 & Mucosa & 39 & $\mathrm{~F}$ & Crônica & Batatais - SP & 2011 & P. brasiliensis sensu stricto $\mathrm{S} 1 \mathrm{~b}$ \\
\hline HCRP 165 & Mucosa & 59 & M & Crônica & Pradópolis - SP & 2012 & P. brasiliensis sensu stricto $\mathrm{S} 1 \mathrm{~b}$ \\
\hline HCRP 168 & Biópsia de língua & 59 & M & Crônica & Sertãozinho - SP & 2014 & P. brasiliensis sensu stricto $\mathrm{S} 1 \mathrm{~b}$ \\
\hline HCRP 170 & Osso sacro & 30 & M & Sub aguda & Taquaritinga - SP & 2014 & P. brasiliensis sensu stricto $\mathrm{S} 1 \mathrm{~b}$ \\
\hline HCRP 171 & Abcesso cerebral & 59 & M & Crônica & Mococa - SP & 2015 & P. brasiliensis sensu stricto $\mathrm{S} 1 \mathrm{a}$ \\
\hline HCRP 175 & Biópsia de pele & 45 & M & Crônica & Caconde - SP & 2015 & P. brasiliensis sensu stricto $\mathrm{S} 1 \mathrm{~b}$ \\
\hline HCRP 176 & Broncoalveolar & 51 & M & Crônica & Ribeirão Preto - SP & 2015 & P. brasiliensis sensu stricto $\mathrm{S} 1 \mathrm{~b}$ \\
\hline HCRP 177 & Biópsia de pele & 43 & M & Crônica & Ribeirão Preto - SP & 2014 & P. brasiliensis sensu stricto $\mathrm{S} 1 \mathrm{~b}$ \\
\hline HCRP 178 & Biópsia de Laringe & 50 & M & Crônica & Ribeirão Preto - SP & 2015 & P. brasiliensis sensu stricto $\mathrm{S} 1 \mathrm{~b}$ \\
\hline HCRP 181 & Biópsia de língua & 49 & M & Crônica & Santa Cruz das Posses - SP & 2015 & P. brasiliensis sensu stricto $\mathrm{S} 1 \mathrm{~b}$ \\
\hline HCRP 183 & Linfonodo & 33 & M & Sub aguda & Serrana - SP & 2016 & P. brasiliensis sensu stricto $\mathrm{S} 1 \mathrm{~b}$ \\
\hline HCRP 186 & Linfonodo & 29 & M & Sub aguda & Serra Azul - SP & 2016 & $P$. brasiliensis sensu stricto $\mathrm{S} 1 \mathrm{~b}$ \\
\hline HCRP 187 & Biópsia de traqueia & 62 & M & Crônica & Barrinha - SP & 2017 & P. brasiliensis sensu stricto $\mathrm{S} 1 \mathrm{~b}$ \\
\hline HCRP 189 & Mucosa & 55 & M & Crônica & Barrinha - SP & 2017 & P. brasiliensis sensu stricto $\mathrm{S} 1 \mathrm{~b}$ \\
\hline HCRP 190 & Broncoalveolar & 48 & M & Crônica & Ribeirão Preto - SP & 2017 & P. brasiliensis sensu stricto $\mathrm{S} 1 \mathrm{~b}$ \\
\hline HCRP 191 & Biópsia de pele & 55 & M & Crônica & Ribeirão Preto - SP & 2017 & P. lutzii \\
\hline HCRP 192 & Cisto sinovial & 45 & M & Sub aguda & Mococa - SP & 2018 & P. brasiliensis sensu stricto $\mathrm{S} 1 \mathrm{~b}$ \\
\hline HCRP 193 & Secreção traqueal & 51 & M & Crônica & Ituverava - SP & 2018 & P. brasiliensis sensu strictoS1a \\
\hline HCRP 195 & Mucosa & 60 & M & Crônica & Ribeirão Preto - SP & 2018 & P. brasiliensis sensu stricto $\mathrm{S} 1 \mathrm{~b}$ \\
\hline
\end{tabular}

Autoria: Fonte Própria. 
Anexo 1 - Tabela Suplementar 1. Isolado, Amostra, Idade, Sexo, Forma clínica, origem geográfica, ano do isolamento fúngico e genótipo dos isolados clínicos submetido a avaliação genotípica neste estudo.

\begin{tabular}{|c|c|c|c|c|c|c|c|}
\hline Isolado & Amostra & Idade & Sexo & Forma Clínica & Origem Geográfica & Ano de Isolamento fúngico & Genótipo \\
\hline HCRP 199 & Biópsia de pele & 57 & M & Crônica & Ribeirão Preto - SP & 2019 & P. americana (PS2) \\
\hline HCRP 200 & Biópsia de pele & 38 & $\mathrm{~T}$ & Crônica & Ribeirão Preto - SP & 2019 & P. brasiliensis sensu stricto $\mathrm{S} 1 \mathrm{~b}$ \\
\hline HCRP FOZ_1 & Escarro & - & - & Crônica & Foz do Iguaçu - PR & 2017 & P. brasiliensis sensu stricto $\mathrm{S} 1 \mathrm{~b}$ \\
\hline HCRP FOZ_2 & Escarro & - & - & Crônica & Foz do Iguaçu - PR & 2017 & P. brasiliensis sensu stricto $\mathrm{S} 1 \mathrm{~b}$ \\
\hline HCRP BAT & Linfonodo & 41 & M & Sub aguda & Ribeirão Preto - SP & 1985 & P. restrepiensis (PS3) \\
\hline HCRP BOAS & Escarro & 56 & M & Crônica & Guatapará - SP & 1996 & P. brasiliensis sensu stricto $\mathrm{S} 1 \mathrm{~b}$ \\
\hline HCRP TONI & Escarro & 36 & M & Crônica & Ribeirão Preto - SP & 1995 & P. brasiliensis sensu stricto $\mathrm{S} 1 \mathrm{~b}$ \\
\hline
\end{tabular}

Autoria: Fonte Própria. 
Anexo 2 - Tabela Suplementar 2: Soros de pacientes do estudo, titulação inicial na reação CIE, data de coleta do soro e respectivo genótipo dos isolados clínicos de Paracoccidioides spp. utilizados para os testes sorológicos.

\begin{tabular}{|c|c|c|c|c|}
\hline Pacientes & $\begin{array}{l}\text { Identificação } \\
\text { Micologia }\end{array}$ & $\begin{array}{l}\text { Data de } \\
\text { coleta do } \\
\text { soro }\end{array}$ & $\begin{array}{l}\text { Titulação } \\
\text { dos soros* }\end{array}$ & $\begin{array}{l}\text { Genótipo do Isolado } \\
\text { Clínico de } \\
\text { Paracoccidioides spp. }\end{array}$ \\
\hline 1 & 1066 & $10 / 01 / 2000$ & $1 / 64$ & $\begin{array}{c}\text { HCRP054 - P. brasiliensis } \\
\text { sensu stricto (S1a) }\end{array}$ \\
\hline 2 & 538 & $25 / 01 / 2011$ & $1 / 128$ & $\begin{array}{c}\text { HCRP149 - P. brasiliensis } \\
\text { sensu stricto (S1a) }\end{array}$ \\
\hline 3 & 382 & $26 / 08 / 2011$ & $1 / 128$ & $\begin{array}{c}\text { HCRP154 - P. brasiliensis } \\
\text { sensu stricto (S1b) }\end{array}$ \\
\hline 4 & 1139 & 20/12/2018 & $1 / 256$ & $\begin{array}{l}\text { HCRP170 - P. brasiliensis } \\
\text { sensu stricto }(\mathrm{S} 1 \mathrm{~b})\end{array}$ \\
\hline 5 & 1099 & 20/10/2016 & $1 / 256$ & $\begin{array}{l}\text { HCRP176 - P. brasiliensis } \\
\text { sensu stricto }(\mathrm{S} 1 \mathrm{~b})\end{array}$ \\
\hline 6 & 243 & 11/02/2019 & $1 / 128$ & $\begin{array}{l}\text { HCRP181 - P. brasiliensis } \\
\text { sensu stricto (S1b) }\end{array}$ \\
\hline 7 & 59 & 19/09/2016 & $1 / 128$ & $\begin{array}{l}\text { HCRP182 - P. brasiliensis } \\
\text { sensu stricto (S1b) }\end{array}$ \\
\hline 8 & 1256 & 23/07/2018 & $1 / 64$ & $\begin{array}{c}\text { HCRP187 - P. brasiliensis } \\
\text { sensu stricto ( } 1 \mathrm{~b})\end{array}$ \\
\hline 9 & 1351 & $12 / 12 / 2017$ & $1 / 128$ & $\begin{array}{c}\text { HCRP189 - P. brasiliensis } \\
\text { sensu stricto (S1b) }\end{array}$ \\
\hline 10 & 218 & 02//04/2018 & $1 / 4$ & HCRP191 - P. lutzii \\
\hline 11 & 1497 & 08/11/2018 & $1 / 64$ & $\begin{array}{l}\text { HCRP193 - P. brasiliensis } \\
\text { sensu stricto (S1a) }\end{array}$ \\
\hline 12 & 640 & 19/02/2018 & $1 / 256$ & $\begin{array}{l}\text { HCRP194 - P. brasiliensis } \\
\text { sensu stricto (S1b) }\end{array}$ \\
\hline 13 & 1267 & 28/01/2019 & $1 / 32$ & $\begin{array}{c}\text { HCRP199 - P. americana } \\
\text { (PS2) }\end{array}$ \\
\hline 14 & 1295 & 28/01/2019 & $1 / 512$ & $\begin{array}{l}\text { HCRP200 - P. brasiliensis } \\
\text { sensu stricto }(\mathrm{S} 1 \mathrm{~b})\end{array}$ \\
\hline 15 & - & $17 / 05 / 1985$ & $1 / 1024$ & $\begin{array}{l}\text { HCRPBAT }-P . \\
\text { restrepiensis (PS3) }\end{array}$ \\
\hline
\end{tabular}

Legenda: * Título obtido na reação com 'pool' de antígenos extraídos de leveduras submetidas a ultrassom. Autoria: Fonte Própria. 
Anexo 3. Comprovante de aprovação do comitê de ética.

HOSPTAL DAS CLINICAS DA FACULDADE DE MEDICINA DE RIBEIRĀO PRETO DA UNIVERSIDADE DE SAOO PAULLO

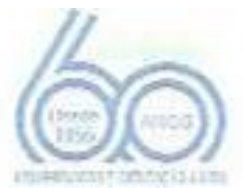

Oficio $\mathrm{n}^{\circ} 1164 / 2017$

CEP/MCSV

PROCESSO HCRP n ${ }^{\circ} 4456 / 2017$

Prezados Pesquisadores,

- trabalho intitulacio "IDENTIFICAÇĀO GENoTíPICA, MICROMORFOLÓGICA, DA VIRULÊNCIA E DE SUSCEPTIBILIDADE A ANTIFÚNGICOS DE ESPÉCIES DE PARACOCCIDIOIDES ISOLADAS DE PACIBNTES DA REGIĀO DE RIBEIRẢO PRETO/SP", foi analisado pelo Comité dc Ėtica cm Pesquisa, em sua $118^{\circ}$ Reuniāo Ordinảria rcalizada cm 17/014/2017, c cnquadrado na calegoria: APROVADO, bem como a solicitacấn de dispensel de aplicacao do Termo de Consentimento Livrc $c$ Esciarecido.

De acordo com Carta Circular $n^{\circ}$ 003/2011/CONER/CNS, datnda de $21 / 03 / 2011$, a sujeito de pesquisa ou seu representante, quando for a caso, deverù rubricar Lodas us folhas do Termo de Consentimenio Litre e Esciarecido - TCLE - apondo sua assinatura na última do neferido Termo; o pescuisador responsabel deverá da mesma forma, nubrioar todas as folhas do Termo de Consentimento tiure e Faciarecido TCLE upondo sua assinatura na siltina página do referido Termo.

Bste Comifê segrue integrulmente a Conferencin internacional de

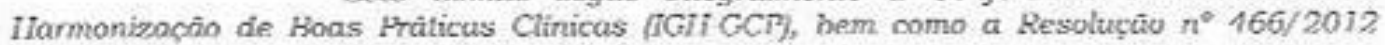
CNS/MS.

lembrumos que devem ser apresentados a este: CEP, o Relatório Parcial e o Relatório Finul clu pesquisa.

Atenciosamentc.



Ilustrissimos Senhores

TIAGO ALEXANDRE COCIO

PROF. DR. ROBERTO MARTINEZ (Orientador)

Depto. de Clinica Módica 
ANEXO DE PUBLICAÇÃO 


\section{ANEXOS DE PUBLICAÇÕES}

\subsection{Publicação 1}

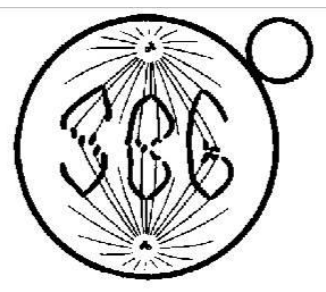

\section{SOCIEDADE BRASILEIRA DE GENÉTICA}

Rua Capitão Adelmio Norberto da Silva 736 - Alto da Boa Vista

14025-670 - Ribeirão Preto - SP - Brasil

Fone 55 16 36218540/Fax: 551636213552

23-Feb-2021

Dear Dr. Cocio:

Your manuscript entitled "Characterization of a Paracoccidioides spp. strain from southeastern Brazil genotyped as Paracoccidioides restrepiensis (PS3) and review of this phylogenetic species" submitted for publication in Genetics and Molecular Biology has been evaluated by the assigned Associate Editor who concluded that you have adequately addressed the concerns raised by the reviewers.

Therefore, I am pleased to inform you that your manuscript is now published.

Genet. Mol. Biol. vol.43 no.2 Ribeirão Preto 2020 Epub May 29, 2020

https://doi.org/10.1590/1678-4685-gmb-2019-0201

\section{GENOMICS AND BIOINFORMATICS}

Characterization of a Paracoccidioides spp. strain from southeastern Brazil genotyped as Paracoccidioides restrepiensis (PS3) and review of this phylogenetic species

Tiago Alexandre Cocio

http://orcid.org/0000-0002-3306-3118

Eduardo Bagagli ${ }^{3}$

http://orcid.org/0000-0002-8003-4109

Erika Nascimento ${ }^{1}$

Marcia R. V. Z. Kress ${ }^{2}$

Roberto Martinez http://orcid.org/0000-0001-6906-7981

${ }^{1}$ Universidade de São Paulo (USP), Faculdade de Medicina de Ribeirão Preto (FMRP), Departamento de Clínica Médica, Ribeirão Preto, SP, Brazil.

2Universidade de São Paulo (USP), Faculdade de Ciências Farmacêuticas de Ribeirão Preto (FCFRP), Departmento de Análises Clínicas, Toxicológicas e Bromatológicas, Ribeirão Preto, SP, Brazil.

3Universidade Estadual Paulista 'Júlio Mesquita Filho' (UNESP), Instituto de Biociências de Botucatu, Departamento de Ciências Químicas e Biológica, Botucatu, SP, Brazil.

On behalf of the Editors of Genetics and Molecular Biology, I would like to take the opportunity to thank you for submitting your interesting contribution to our journal.

Sincerely,



Dr. Carlos Menck

Editor in Chief, Genetics and Molecular Biology

editor@gmb.org.br 
Genetics and Molecular Biology, 43, 2, e20190201 (2020)

Copyright (C) 2020, Sociedade Brasileira de Genética.

DOI: https://doi.org/10.1590/1678-4685-GMB-2019-0201

Research Article

Genomics and Bioinformatics

\title{
Characterization of a Paracoccidioides spp. strain from southeastern Brazil genotyped as Paracoccidioides restrepiensis (PS3) and review of this phylogenetic species
}

\author{
Tiago Alexandre Cocio $^{1}\left(\mathbb{D}\right.$, Erika Nascimento ${ }^{1}$, Marcia R. V. Z. Kress $^{2}$, Eduardo Bagagli ${ }^{3}$, Roberto \\ Martinez ${ }^{1}$ (D) \\ ${ }^{1}$ Universidade de São Paulo (USP), Faculdade de Medicina de Ribeirão Preto (FMRP), Departamento de \\ Clínica Médica, Ribeirão Preto, SP, Brazil. \\ ${ }^{2}$ Universidade de São Paulo (USP), Faculdade de Ciências Farmacêuticas de Ribeirão Preto (FCFRP), \\ Departmento de Análises Clínicas, Toxicológicas e Bromatológicas, Ribeirão Preto, SP, Brazil. \\ ${ }^{3}$ Universidade Estadual Paulista 'Júlio Mesquita Filho' (UNESP), Instituto de Biociências de Botucatu, \\ Departamento de Ciências Quimicas e Biológica, Botucatu, SP, Brazil.
}

\begin{abstract}
Phylogenetic species of Paracoccidioides brasiliensis complex (S1a and S1b, PS2, PS3, and PS4) and Paracoccidioides lutzii are agents of paracoccidioidomycosis, an endemic fungal disease in Latin America. P. restrepiensis (PS3 genotype) was classified as monophyletic and geographically restricted to Colombia and neighboring territories. BAT (or Pb-327B) was isolated from a patient living in the southeast region of Brazil but with genotype similar to Colombian Paracoccidioides spp. strains. This study aimed to define the phylogenetic species of BAT isolate by using additional genotyping methods, as well as reviewing the epidemiological and clinical studies related to $P$. restrepiensis isolates. Genomic DNA of BAT isolate and reference strains of $P$. brasiliensis sensu stricto (S1b), $P$. americana (PS2), $P$. restrepiensis (PS3), and $P$. lutzii were analyzed by conventional polymerase chain reaction (PCR) of partial gp43 exon 2 loci, by PCR-RFLP technique of tub1 gene, and by sequencing of the whole gp 43 exon 2 loci. Here, we show that BAT isolate belongs to $P$. restrepiensis species, which is an unusual identification in southeastern Brazil, where $P$. brasiliensis sensu stricto is the prevalent genotype. This identification has relevance for geographical distribution and propagation of the genus Paracoccidioides in South America.
\end{abstract}

Keywords: Paracoccidioides restrepiensis, Paracoccidioides brasiliensis PS3, phylogenetic species, evolution, paracoccidioidomycosis epidemiology.

Received: June 20, 2019; Accepted: March 09, 2020.

\section{Introduction}

Paracoccidioidomycosis (PCM) is a systemic fungal infection endemic and restricted to Latin American countries such as Brazil, Argentina, Colombia, and Venezuela (Martinez, 2017). Pathogens that cause the acute and chronic forms of PCM are thermodimorphic fungi belonging to the genus Paracoccidioides, family Ajellomycetaceae, order Onygenales, class Eurotiomycetes, and species Paracoccidioides brasiliensis and Paracoccidioides lutzii (Gonzalez and Hernandez, 2016). P. brasiliensis clade is composed of five phylogenetic species, in which S1a and S1b belong to the paraphyletic group distributed in Brazil, Argentina, Paraguay, Peru, and Venezuela; PS2 belongs to the monophyletic group distributed in Brazil and Venezuela; PS3 belongs to

Send correspondence to: Tiago Alexandre Cocio. Universidade de São Paulo (USP), Faculdade de Medicina de Ribeirão Preto, Departamento de Clínica Médica. Av. Bandeirantes, 3900, Monte Alegre, Ribeirão Preto, São Paulo, Brazil, Postal Code: 14049-900. Phone/Fax: 55-16-3602-2468; E-mail: alexcocio@ gmail.com the monophyletic group found mainly in Colombia; and the PS4 monophyletic group is found exclusively in Venezuela (Matute et al., 2006; Carrero et al., 2008; Teixeira et al., 2009; Teixeira et al., 2014; Muñoz et al., 2016). Turissini et al. (2017) analyzed microsatellites, mitochondrial and nuclear genes, proposing four new species belonging to the genus Paracoccidioides: $P$. brasiliensis sensu stricto (S1a and S1b), $P$. americana (PS2), $P$. restrepiensis (PS3), and $P$. venezuelensis (PS4). These species show among them genotypic and micromorphological divergences (Turissini et al., 2017). The $P$. lutzii clade contains exclusively $P$. lutzii (Teixeira et al., 2009).

Phylogenetic species 3 (PS3), now $P$. restrepiensis, was characterized by Matute et al. (2006) and classified as monophyletic, geographically restricted to Colombia, and considered an evolutionary lineage independent of other phylogenetic species of Paracoccidioides spp. complex. The same authors described the phylogenetic relationship of $P$. restrepiensis (PS3) with other species of $P$. brasiliensis 
complex, showing ancestral proximity to $P$. brasiliensis sensu stricto (S1a and $\mathrm{S} 1 \mathrm{~b})$, but having a greater genetic distance from P. americana (PS2). Munõz et al. (2016), when analyzing genotypic divergences among the phylogenetic species, verified the ancestral proximity of Colombian $P$. restrepiensis (PS3) isolates with Venezuelan isolates of $P$. venezuelensis (PS4) and Argentinian and Brazilian isolates of $P$. brasiliensis sensu stricto ( $\mathrm{S} 1 \mathrm{a}$ and $\mathrm{S} 1 \mathrm{~b}$ ). Besides the genetic proximity of $P$. restrepiensis (PS3) to other phylogenetic species of $P$. brasiliensis complex, Roberto et al. (2016) characterized two strains (human isolate chronic form PCM, and soil isolate) obtained in the Venezuelan territory as PS3 (now $P$. restrepiensis), suggesting its regional dissemination in South America.

This study aimed to characterize a clinical isolate from southeastern Brazil as P. restrepiensis (PS3), an unusual finding in such geographical area. Additionally, a review has been presented with studies on human and environmental isolates of the same genotype.

\section{Material and Methods}

\section{Paracoccidioides spp. isolates and culture conditions}

BAT (also known as Pb-327-B) clinical strain was isolated in 1985 from a suppurated lymph node of a patient resident in a city belonging to the metropolitan region of Ribeirão Preto, São Paulo State, Brazil ( $21^{\circ} 10^{\prime} 13.44^{\prime \prime}$ S and $\left.47^{\circ} 48^{\prime} 37.17^{\prime \prime} \mathrm{W}\right)$. The patient was a 33 -year-old male rural worker who had the subacute form of PCM manifested by generalized lymphadenomegaly, hepatosplenomegaly, disseminated cutaneous lesion, fungal lesions in duodenal and colonic mucosa, and jaundice. The patient denied previous disease history or travel to other Brazilian states and South American countries. PCM diagnosis was supported by Paracoccidioides spp. isolation in culture, histopathological examination of intestinal lesions, and a 1:1024 serum titer in the counterimmunoelectrophoresis for anti-Paracoccidioides spp. antibodies. The patient obtained clinical cure after two years of treatment with sulfa drugs.

The following reference strains, whose genotypes were determined in other studies, were employed for BAT clinical isolate comparison: $\mathrm{Pb} 18$ - representative of $P$. brasiliensis sensu stricto (S1b) species (Matute et al., 2006); $\mathrm{Pb}$ dog-EPM 194-representative of $P$. americana (PS2) species and T2-EPM 54-representative of $P$. restrepiensis (PS3) species (Roberto et al., 2016); and $\mathrm{Pb} 01$ representative of $P$. lutzii (Teixeira et al., 2009). All the strains are maintained by successive subcultures on Sabouraud Agar Dextrose medium (Oxoid) plus $0.15 \mathrm{~g} \mathrm{l}^{-1}$ chloramphenicol sodium succinate (Blau Farmacêutica), and incubated at $25{ }^{\circ} \mathrm{C}$. The study was approved by the Research Ethics Committee of the Hospital das Clínicas of Ribeirão Preto Medical School, University of São Paulo (Protocol HCRP n ${ }^{\circ} 4456 / 2017$ ).

\section{Genomic DNA extraction of Paracoccidioides spp. strains}

The genomic DNA of Paracoccidioides spp. strains were obtained from the fungal mycelia, which were grown in a synthetic modified McVeigh-Morton liquid medium for 35 days at $25^{\circ} \mathrm{C}$ in an orbital shaker at $130 \mathrm{rpm}$ (Infors HTEcotron) (Restrepo and Jimenez, 1980). The mycelia were subjected to extraction of genomic DNA according to the method I (treated glass beads and phenol-chloroform-isoamyl alcohol), with minimal modifications (van Burik et al., 1998). The genomic DNA was treated with $300 \mathrm{ng} \mathrm{ml}^{-1}$ RNase $\mathrm{A}^{\circledR}$ (Thermo Fisher Scientific) at $37^{\circ} \mathrm{C}$ for one hour. The concentration of genomic DNA was determined by using NanoDrop $2000^{\mathbb{B}}$ (Thermo Fisher Scientific) and its integrity checked in $1 \%$ agarose gel using SYBR ${ }^{\circledR}$ Safe DNA gel stain (Thermo Fisher Scientific) and visualized using the ChemiDoc XRS+ imager with Image Lab software (BioRad).

\section{Partial gp43 exon 2 loci PCR amplification}

To identify and classify BAT clinical isolate into the genus Paracoccidioides, the genomic DNA of Paracoccidioides spp. reference strains and BAT isolate were submitted to partial amplification of the gp 43 exon 2 loci by using the primers gp43-E2F: (5- CCA GGA GGC GTG CAG GTG TCC C - 3) and gp43-E2R: (5- GCC CCC TCC GTC TTC CAT GTC C - 3) (Cisalpino et al., 1996; Roberto et al., 2016) at $10 \mathrm{mM}$ concentration, and annealing temperature at $58^{\circ} \mathrm{C}$. PCR reaction was performed with Taq polymerase enzyme-GoTaq ${ }^{\circledR}$ Green Master Mix (Promega) according to the manufacturer's instructions. The final volume of PCR reaction was $25 \mu \mathrm{l}$, containing $500 \mathrm{ng}$ genomic DNA. Thermocycling was performed in the Vapo Protect ${ }^{\circledR}$ thermocycler (Eppendorf). PCR products, approximately $533 \mathrm{bp}$, had their integrity verified in $2 \%$ agarose gel by using SYBR $®$ Safe DNA gel stain (Thermo Fisher Scientific). Its molecular weight was determined by 100 -bp Ladder marker, Ready-To-Use (Sinapse), and visualized and photographed on the ChemiDoc XRS+ imager with Image Lab software (Bio-Rad).

\section{Polymerase Chain Reaction - Restriction Fragment Length Polymorphism of tub1 gene - PCR-RFLP}

Phylogenetic species identification of BAT clinical isolate was made according to Roberto et al. (2016). Briefly, PCR-RFLP of alpha-tubulin ( $t u b 1$ ) gene was performed with Taq polymerase-GoTaq ${ }^{\circledR}$ Green Master Mix enzyme (Promega). The final volume of PCR reaction was $25 \mu$, containing $500 \mathrm{ng}$ genomic DNA and the primers tublF: (5-CTG GGA GGT ATG ATA ACA CTG C-3) and tublR: (5- CGT CGG GCT ATT CAG ATT TAA G -3) (Kasuga et al., 2002; Roberto et al., 2016) at a concentration of $10 \mathrm{mM}$, and annealing temperature of $58^{\circ} \mathrm{C}$. PCR $t u b 1$ products $(263 \mathrm{bp})$ were cleaved with $B c l I$ and $M s p I$ endonucleases (Thermo


${ }^{\circ} \mathrm{C}$ per 16 hours, according to manufacturer's instructions. 
Cleaved DNA fragments were visualized in $2.5 \%$ agarose gel at $70 \mathrm{~V}$ for 140 minutes in presence of SYBR ${ }^{\circledR}$ Safe DNA gel stain (Thermo Fisher Scientific) and 50 bp DNA ladder molecular marker (Sinapse) and compared according to the method described by Roberto et al. (2016).

\section{Sequencing of gp43 exon 2 loci}

To validate the $t u b 1$ gene PCR-RFLP method, gp43 exon 2 loci was sequenced using the primers Pbgp43-E2F: (5-CTA GAA TAT CTC ACT CCC AG-3) and Pb_gp43-E2R: (5-GCC CCC TCC GTC TTC CAT GTC C-3) (Cisalpino et al., 1996; Hrycyk et al., 2018) at a concentration of $20 \mathrm{mM}$ and annealing temperature of $58{ }^{\circ} \mathrm{C}$. PCR product of gp 43 exon 2 loci, approximately 722 bp, had nonspecific amplification and/or integrity verified in $2 \%$ agarose gel. Then PCR amplicons were purified using Wiz$\operatorname{ard}^{\mathbb{B}}$ SV Gel and PCR Clean-Up System kit (Promega), as instructed by the manufacturer. DNA sequences were determined with an ABI3730 DNA Analyzer (Applied Biosystems), using the BigDye ${ }^{\circledR}$ Terminator v3.1 Cycle Sequencing Kit (Thermo Fisher Scientific). Chromatograms were analyzed with ChromasPro ${ }^{\circledR}$ software (ChromasPro 2.6.5). The DNA sequences were compared to nucleotide database using the Basic Local Alignment Search Tool (blastn): https://blast.ncbi.nlm.nih.gov/Blast.cgi(Altschul et al., 1990). The sequences of $g p 43$ exon 2 loci determined in this study were submitted to alignment and analysis of similar and conserved regions, using Clustal Omega software https:/www.ebi.ac.uk/Tools/msa/clustalo/ (Sievers et al., 2011).

BAT clinical isolate sequence of $g p 43$ exon 2 loci was deposited at GenBank: (https://www.ncbi.nlm.nih.gov/genbank/) under accession number MH484614.

\section{Results \\ BAT clinical isolate belongs to the genus Paracoccidioides}

Genomic DNA from Paracoccidioides spp. reference strains and BAT isolate were subjected to standard PCR to partially amplify gp 43 exon 2 loci. A PCR product of approximately 533 bp (Figure 1A) was observed, confirming that all study samples, including BAT clinical isolate, belong to the genus Paracoccidioides.

\section{Molecular characterization of BAT clinical isolate as $P$. restrepiensis (PS3)}

The tub 1 gene of Paracoccidioides spp. reference strains and BAT isolate were PCR amplified, and $263 \mathrm{bp} \mathrm{am}-$ plification products were observed (Figure 1B). BAT clinical isolate was identified as $P$. restrepiensis (PS3) (Figure 1C) since the $263 \mathrm{bp}$ fragment of the $t u b 1$ gene does not have cleavage sites for $B c l I$ and $M s p I$ endonucleases; thus, it was maintained in its complete integrity (263 bp). The reference strains $\mathrm{Pb}$ 18, Pb dog-EPM194, T2 -EPM54, and Pb 01 had DNA fragment patterns produced by the endonucleases, as described by Roberto et al. (2016), validating the molecular identification of BAT isolate species by PCR-RFLP as $P$. restrepiensis (PS3) genotype (Figure 1C). The whole gp 43 exon 2 loci of BAT clinical isolate was sequenced to confirm the result obtained by PCR-RFLP. The gp 43 exon 2 loci DNA sequence showed $100 \%$ identity for nucleotide sequence of the reference strain T2-EPM54 P. restrepiensis (PS3). Alignment of nucleotide sequences of the gp 43 exon 2 loci of BAT clinical isolate and the reference strains also showed genetic proximity with $\mathrm{Pb} 18-P$. brasiliensis sensu stricto (S1b), but greater phylogenetic distance from $\mathrm{Pb}$ dog EPM194 - P. americana (PS2) and from Pb01 (P. lutzii) (Figure 2).

The geographical origin of BAT clinical isolate and of the other Paracoccidioides spp. isolates classified as $P$. restrepiensis (PS3 genotype) are shown in Figure 3.


Figure 1 - (A) Partial amplification of the gp43 exon 2 loci of Paracoccidioides spp. by conventional PCR of BAT clinical isolate and reference isolates. M: 100 bp DNA ladder molecular marker, Ready-To-Use (Sinapse ${ }^{\circledR}$ Inc., United States). (B) Amplification of the tub1 gene by PCR-RFLP. M: 50 bp DNA ladder molecular marker (Sinapse ${ }^{\circledR}$ Inc., United States). (C) PCR-RFLP DNA fragment patterns obtained after cleavage with BcII and $M s p I$ endonucleases, showing similarity of BAT clinical isolate with T2-EPM54 (P. restrepiensis - PS3 reference strain). M: 50 bp DNA ladder molecular marker (Sinapse ${ }^{\circledR}$ Inc., United States). Pb 18: P. brasiliensis sensu stricto (S1b); Pb dog-EPM 194: P. americana (PS2); T2-EPM 54: P. restrepiensis (PS3); and $\mathrm{Pb}$ 01: P. lutzii; BAT: Clinical isolate under study. 


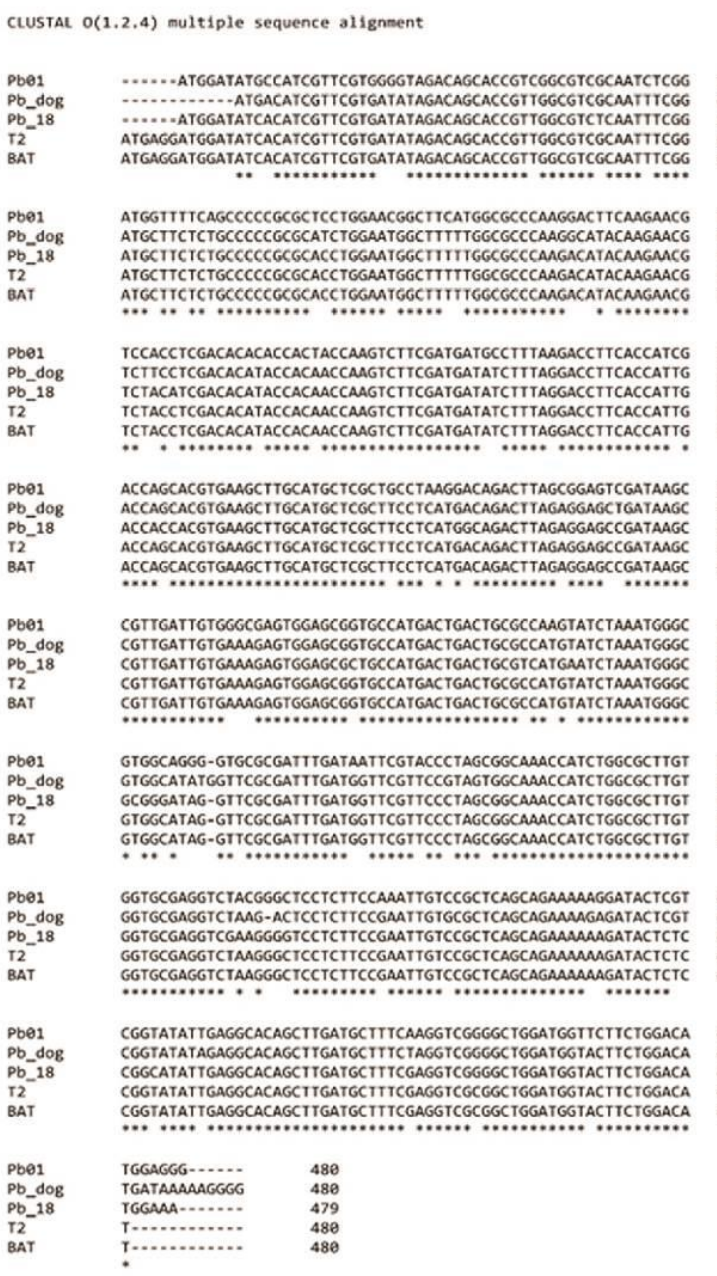

Figure 2 - Alignment of gp 43 exon 2 loci nucleotide sequences from Paracoccidioides spp. reference strains and BAT clinical isolate. The identity between BAT isolate and T2-EPM54 $(P$. restrepiensis - PS3 reference strain) was observed, as well as genetic proximity with $\mathrm{Pb} 18(P$ brasiliensis sensu stricto $-\mathrm{S} 1 \mathrm{~b})$ but with greater phylogenetic distance from $\mathrm{Pb}$ dog-EPM194 (P. americana-PS2) and $\mathrm{Pb} 01$ (P. lutzii). *: represents similar nucleotides in the analyzed sequences.

\section{Discussion}

BAT clinical strain was isolated in 1985 and maintained at the Ribeirão Preto Medical School-USP, southeastern Brazil. It was classified as $P$. restrepiensis (PS3) by sequencing of gp 43 exon 2 loci and PCR-RFLP of $t u b 1$ gene. This result was unexpected since phylogenetic species of PS3 ( $P$. restrepiensis) have so far been isolated in Colombia and Venezuela, countries in northwestern South America. A sample of this strain was sent to Venezuela in the 1990s and included in two investigations on genetic diversity of Paracoccidioides spp. These studies showed a genotypic difference between BAT clinical isolate and other Brazilian isolates. First, BAT isolate (named $\mathrm{Pb} 327-\mathrm{B}$ ) was evaluated together with $32 P$. brasiliensis clinical and envi-

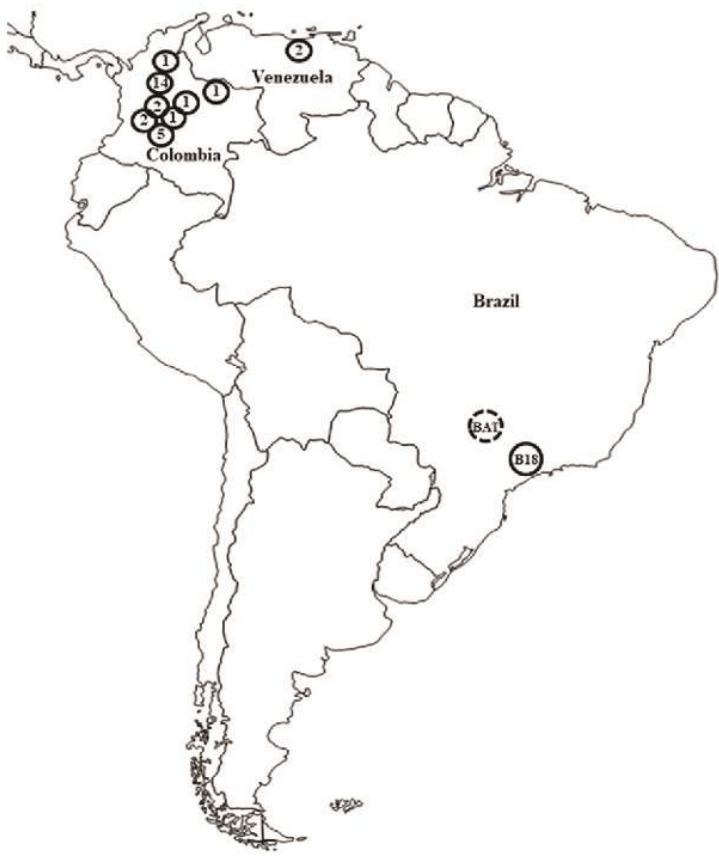

Figure 3 - Geographic distribution of human and environmental isolates of $P$. restrepiensis (PS3 genotype) in South America. Each circle represents the identified isolates and their respective regions (Colombia and Venezuela) according to reports in the literature (Matute et al., 2006; Muñoz et al., 2016; Roberto et al., 2016). In Brazil: BAT clinical isolate (PCM-subacute form) isolated from a patient in the macro-region of Ribeirão Preto, São Paulo State, Brazil, and B18 or Pb339 was isolated from a patient in the state of São Paulo, Brazil.

ronmental isolates from different South American countries. By employing randomly amplified polymorphic DNA (RAPD), BAT isolate was grouped near $P$. brasiliensis isolates from Colombia, which was later classified as PS3 genotype (Calcagno et al., 1998). All 33 P. brasiliensis isolates but one had their DNA analyzed by restriction fragment length polymorphism (RFLP), using HinfI and HincII endonucleases. The dendrogram showed a great relationship of BAT clinical isolate with Colombian $P$. brasiliensis strains (Nino-Vega et al., 2000).

Some phenotypic characteristics of BAT isolate were evaluated. Micromorphological aspects, virulence for guinea pig, and serological reaction of BAT-isolate exoantigen with rabbit anti GP43 serum were typical traits of $P$. brasiliensis strains (Lacaz CS et al., 1999). Compared to other $P$. brasiliensis isolates, BAT isolate had high exoantigen production, which was recognized by sera from patients with PCM in southeastern Brazil (Silva-Vergara et al., 1998; Panunto-Castelo et al., 2003). BAT clinical isolate has been used as a source of antigens of Paracoccidioides spp. in serological tests for PCM diagnosis, since it, together with antigens of other strains, formed a pool with high reactivity against sera from PCM patients from São Paulo state, Brazil (Vidal et al., 2014). Sera from patients infected by P. brasiliensis $\mathrm{S} 1$ genotype reacted with BAT isolate exoantigen in immunodiffusion test (data not shown). Paracoccin, a 160 
$\mathrm{kDa}$ Glc-NAc-binding lectin of the BAT isolate yeast wall, adhered to laminin and induced $\mathrm{TNF} \alpha$ and $\mathrm{NO}$ production by macrophage cells (Coltri et al., 2006).

To date, 31 P. restrepiensis (PS3) strains (clinical and environmental isolates) have been identified and reported in the literature. The studies encompassed phylogeny, molecular characterization, morphology, serology, and/or epidemiology (Table 1). The geographic distribution of isolates characterized as $P$. restrepiensis (PS3), including BAT clinical strain, is predominant in Colombia, totaling $87.2 \%$ of the 31 isolates, followed by $6.4 \%$ in Venezuela, and $6.4 \%$ in Brazil (Matute et al., 2006; Muñoz et al., 2016; Roberto et al., 2016). The occurrence of $P$. restrepiensis (PS3) in other South American countries (Brazil and Venezuela) suggests that its geographical distribution is not restricted to the Colombian territory as initially presumed. It is believed that the phylogeographic characteristics of $P$. restrepiensis (PS3) are due to a possible and relatively recent biogeographic expansion of $P$. brasiliensis sensu stricto ( $\mathrm{S} 1 \mathrm{a}$ and $\mathrm{S} 1 \mathrm{~b}$ ) to Colombia, associated to events of geographic barriers represented by the uplifting of the Andes mountain range and submersion of the Colombian territory by formation of the PebasSolimões lake (Wesselingh and Salo, 2006; Teixeira et al., 2014). The emergence of $P$. restrepiensis (PS3) in Brazil was not clarified within the process of speciation of these phylogenies, due to absence of a geographical barrier in the territory (Teixeira et al., 2014).

Besides the geographical origin of $P$. restrepiensis (PS3), the respective clinical manifestation of PCM is one of the important aspects for understanding of the pathogenicity of this phylogenetic species. Among the 31 P. restrepiensis (PS3) isolates described in the literature, including BAT isolate, $25(76 \%)$ strains were isolated from patients. The chronic form of PCM was more prevalent in patients infected with $P$. restrepiensis (PS3), representing $88 \%$ of the cases. Acute/subacute forms of PCM caused by $P$. restrepiensis (PS3) were only reported in two patients, including that with a disseminated disease from which the strain evaluated in this study was isolated (Matute et al., 2006; Muñoz et al., 2016; Roberto et al., 2016). In a comparative study of PCM cases caused by $P$. brasiliensis sensu stricto ( $\mathrm{S} 1 \mathrm{a}$ and $\mathrm{S} 1 \mathrm{~b}$ ) and $P$. americana (PS2) in Rio de Janeiro state-Brazil, the prevalence of chronic form was observed for both species (de Macedo et al., 2019). The same was observed in a clinical and epidemiological study of PCM caused by $P$. lutzii in the state of Mato Grosso-Brazil, wherein all patients were diagnosed with the chronic form (Hahn et al., 2019). In general, chronic form predominance is common in PCM, so it does not distinguish $P$. restrepiensis (PS3) genotype in this regard.

Some of the Paracoccidioides spp. isolates characterized as $P$. restrepiensis (PS3) have already had their biology studied (Matute et al., 2006; Theodoro et al., 2008). Genotypic and phenotypic studies for $P$. restrepiensis (PS3) isolates were fungal antigenicity (Restrepo-Moreno and Schneidau, 1967), ketoconazole susceptibility (Hoyos et al., 1984), murine immune response to PCM, conidia morphol-

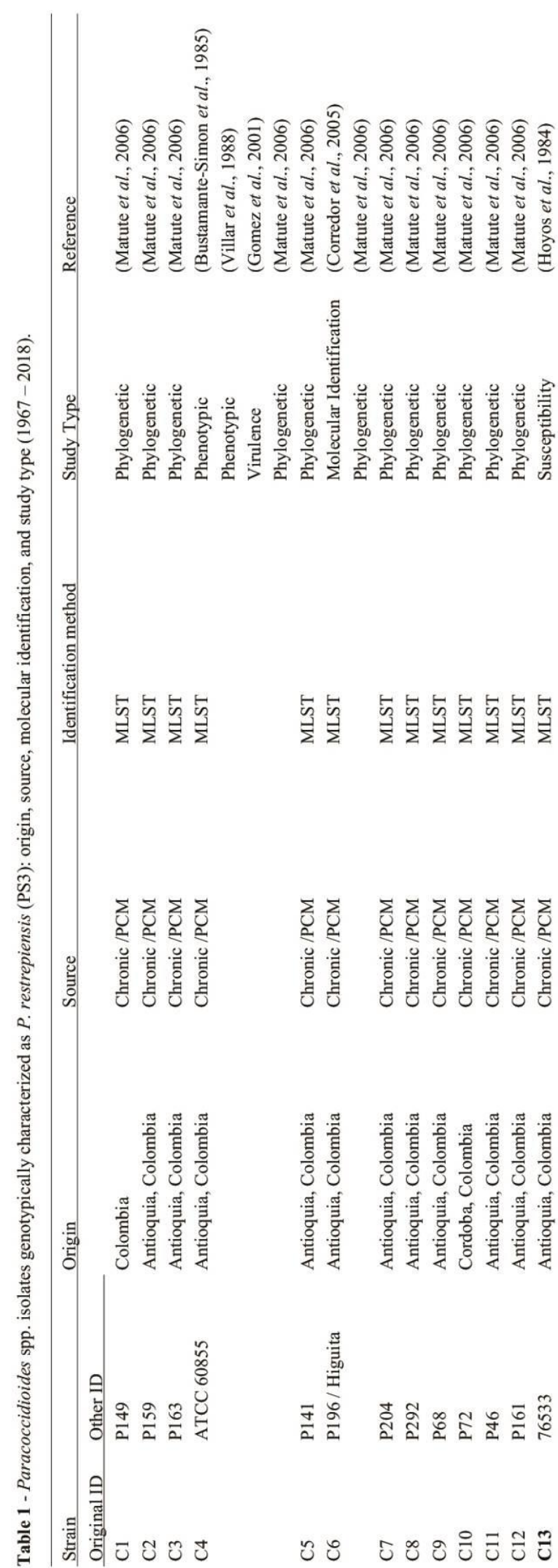





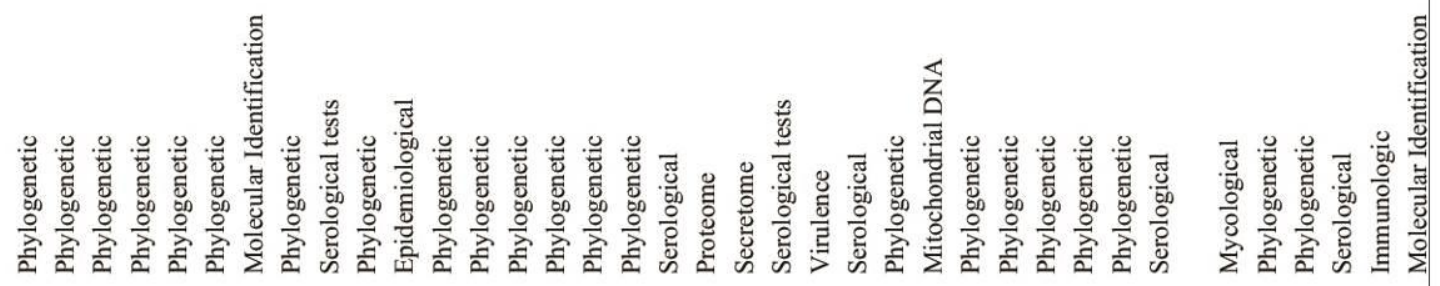

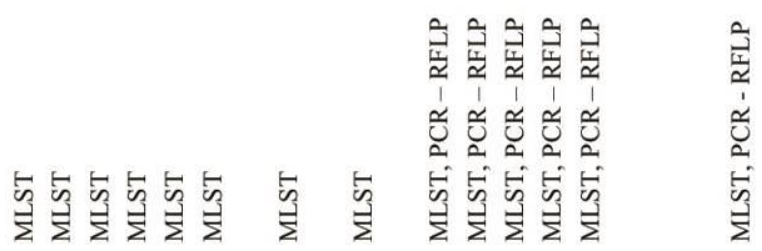

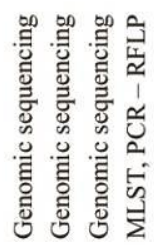



ogy and sporulation at different culture media (BustamanteSimon et al., 1985), dimorphism (Villar et al., 1988), morphological analysis and molecular identification of armadillo isolates (Corredor et al., 1999), and melanin production (Gomez et al., 2001). Other studies compared P. restrepiensis (PS3) isolates with different species belonging to Paracoccidioides spp. complex (P. brasiliensis sensu stricto (S1), P. americana (PS2)) to evaluate genotypic and phenotypic differences. Corredor et al. (2005) studied polymorphic genes (gp43 exon 2 loci, ITS_1, and ITS_4) from clinical and armadillo strains isolated in the Colombian territory, comparing them with strains isolated in other South American countries. Polymorphic differences were found among genes when compared to strains identified as $P$. brasiliensis sensu stricto $(\mathrm{S} 1)$; $P$. restrepiensis (PS3) showed high differentiation from other species (Corredor et al., 2005; Matute $e t$ al., 2006). PRP8 intein protein gene sequences from species of the Paracoccidioides spp. complex, including $P$. restrepiensis EPM83, were analyzed in a phylogenetic study. This gene can be used as a molecular marker since its polymorphism can separate species from the $P$. brasiliensis complex and $P$. lutzii (Theodoro et al., 2008).

Some studies were directed to a phenotypic comparison of $P$. restrepiensis (PS3) isolates and other species belonging to the Paracoccidioides spp. (Table 2). Turissini et al. (2017) carried out a phenotypic study on yeast cells of cryptic species of $P$. brasiliensis complex (S1, PS2, PS3, and PS4) and $P$. lutzii. These authors observed that $P$. restrepiensis (PS3) has yeast cells larger than $P$. brasiliensis sensu stricto (S1) and P. americana (PS2) ones but no cell size differences with $P$. venezuelensis (PS4) and $P$. lutzii strains. A comparative study to evaluate PCM immunodiagnosis using species of the $P$. brasiliensis complex and $P$. lutzii showed higher GP43 production and best antigenic reactivity in an immunodiffusion assay with the EPM83 strain $(P$. restrepiensis - PS3) when tested with sera from patients living in a geographic area where $P$. brasiliensis sensu stricto (S1a e $\mathrm{S} 1 \mathrm{~b})$ and $P$. americana (PS2) are prevalent (Machado et al., 2013). Another comparative study of proteomes by disrupting yeast cells of Paracoccidioides species representative isolates showed that EPM83 (P. restrepiensis - PS3) preferentially expressed 38 proteins, including heat shock proteins (HSP) and a higher level of GP43 production (Pigosso et al., 2013). An analysis of secretomes of two Paracoccidioides spp strains identified 95 extracellular proteins, 35 specific of $P$. lutzii and 36 specific of $P$. restrepiensis (PS3), including several ones related to fungal virulence factors and adhesion (de Oliveira et al., 2018).

$\mathrm{B} 18$ or $\mathrm{Pb} 339$ (ATCC32069) is a strain that has been reported in the literature to have divergent results regarding its classification as $P$. restrepiensis (PS3). It is originally from the state of São Paulo (Brazil) but from an unknown source. This strain was obtained from the National Communicable Disease Center (Atlanta, USA) and first studied by Restrepo-Moreno and Scheneidau JD in 1967. Matute et al. (2006) classified B18 as P. brasiliensis sensu stricto (S1b) by analyses of polymorphisms in nuclear genes, chitin syn- 
thase (CHS) 2, glucan synthase (FKS), tub1 (TUB), adenyl ribosylation factor (ARF), and $g p 43$ exon 2 loci. On the other hand, Salgado-Salazar et al. (2010) studied polymorphism of five mitochondrial genes used as markers in molecular characterization of Paracoccidioides species. The findings enabled reclassification of B18 strain as $P$. restrepiensis (PS3) from Paracoccidioides spp. complex (Salgado-Salazar et al., 2010). Later, Roberto et al. (2016) evaluated B18 strain, termed in that study as B339 and /or EPM01 (ATCC200273) (Camargo et al., 2003), and classified B18 strain as $P$. restrepiensis (PS3) by PCR-RFLP of $t u b 1$ gene and sequencing of CHS2, FKS, TUB, ARF, and GP43 nuclear genes, the same ones studied by Matute $e$ t al. (2016). A study conducted by Turissini et al. (2017) classified B18 strain as an independent genotype due to its phylogenetic and micromorphological differences already observed in previous studies, suggesting a hybrid species belonging to the genus Paracoccidioides.

Identification of an unusual genotypic variant in southeastern Brazil contributes to understanding speciation and propagation involving PCM agents and may help in knowing $P$. restrepiensis characteristics (PS3 genotype) such as morphology, virulence, and serological reactivity.

\section{Acknowledgments}

T. A. Cocio thanks Prof. Dr Zoilo Pires de Camargo, Department of Microbiology, Immunology, and Parasitology, Federal University of São Paulo - SP (Brazil) for kindly ceding Pb dog-EPM194 and T2-EPM54 strains used in this study, the Coordenação de Aperfeiçoamento de Pessoal de Nível Superior - (CAPES Brazil - Finance Code 001) for by granting doctoral and postdoctoral scholarships [Grant num$\begin{array}{lll}\text { bers: } 88882.180015 / 2018-01 & \text { (T.A.C.) and }\end{array}$ 88882.317609/2019-1 (E.N.)], and the Fundação de Apoio ao Ensino, Pesquisa e Assistência do Hospital das Clínicas da Faculdade de Medicina de Ribeirão Preto da Universidade de São Paulo (FAEPA) for financial support.

\section{Conflicts of interest}

The authors declare no conflicts of interest.

\section{Author Contributions}

TAC conducted all experiments, analyzed the results, and contributed to manuscript writing and preparation; EN collaborated in carrying out experiments, analyzing the results, and provided suggestions for the manuscript; MRVZK and EB guided execution of some experiments, analysis of results, and gave suggestions for writing the manuscript; RM supervised study development and wrote the manuscript.

\section{References}

Altschul SF, Gish W, Miller W, Myers EW and Lipman DJ (1990) Basic local alignment search tool. J Mol Biol 215:403-410.

Bustamante-Simon B, McEwen JG, Tabares AM, Arango M and Restrepo-Moreno A (1985) Characteristics of the conidia pro- duced by the mycelial form of Paracoccidioides brasiliensis. Sabouraudia 23:407-414.

Calcagno AM, Nino-Vega G, San-Blas F and San-Blas G (1998) Geographic discrimination of Paracoccidioides brasiliensis strains by randomly amplified polymorphic DNA analysis. J Clin Microbiol 36:1733-1736.

Camargo ZP, Berzaghi R, Amaral CC and Silva SH (2003) Simplified method for producing Paracoccidioides brasiliensis exoantigens for use in immunodiffusion tests. Med Mycol 41:539-542.

Carrero LL, Nino-Vega G, Teixeira MM, Carvalho MJ, Soares CM, Pereira M, Jesuino RS, McEwen JG, Mendoza L, Taylor JW et al. (2008) New Paracoccidioides brasiliensis isolate reveals unexpected genomic variability in this human pathogen. Fungal Genet Biol 45:605-612.

Cisalpino PS, Puccia R, Yamauchi LM, Cano MI, da Silveira JF and Travassos LR (1996) Cloning, characterization, and epitope expression of the major diagnostic antigen of Paracoccidioides brasiliensis. J Biol Chem 271:4553-4560.

Coltri KC, Casabona-Fortunato AS, Gennari-Cardoso ML, Pinzan CF, Ruas LP, Mariano VS, Martinez R, Rosa JC, PanuntoCastelo A and Roque-Barreira MC (2006) Paracoccin, a GlcNAc-binding lectin from Paracoccidioides brasiliensis, binds to laminin and induces TNF-alpha production by macrophages. Microbes Infect 8:704-713.

Corredor GG, Castano JH, Peralta LA, Diez S, Arango M, McEwen $\mathrm{J}$ and Restrepo A (1999) Isolation of Paracoccidioides brasiliensis from the nine-banded armadillo Dasypus novemcinctus, in an endemic area for paracoccidioidomycosis in Colombia. Rev Iberoam Micol 16:216-220.

Corredor GG, Peralta LA, Castano JH, Zuluaga JS, Henao B, Arango M, Tabares AM, Matute DR, McEwen JG and Restrepo A (2005) The naked-tailed armadillo Cabassous centralis (Miller 1899): a new host to Paracoccidioides brasiliensis. Molecular identification of the isolate. Med Mycol 43:275-280.

de Macedo PM, Teixeira MM, Barker BM, Zancope-Oliveira RM, Almeida-Paes R and Francesconi do Valle AC (2019) Clinical features and genetic background of the sympatric species Paracoccidioides brasiliensis and Paracoccidioides americana. PLoS Negl Trop Dis 13:e007309.

de Oliveira AR, Oliveira LN, Chaves EGA, Weber SS, Bailao AM, Parente-Rocha JA, Baeza LC, de Almeida Soares CM and Borges CL (2018) Characterization of extracellular proteins in members of the Paracoccidioides complex. Fungal Biol 122:738-751.

Gomez BL, Nosanchuk JD, Diez S, Youngchim S, Aisen P, Cano LE, Restrepo A, Casadevall A and Hamilton AJ (2001) Detection of melanin-like pigments in the dimorphic fungal pathogen Paracoccidioides brasiliensis in vitro and during infection. Infect Immun 69:5760-5767.

Gonzalez A and Hernandez O (2016) New insights into a complex fungal pathogen: the case of Paracoccidioides spp. Yeast 33:113-128.

Hahn RC, Rodrigues AM, Della Terra PP, Nery AF, HoffmannSantos HD, Gois HM, Fontes CJF and de Camargo ZP (2019) Clinical and epidemiological features of paracoccidioidomycosis due to Paracoccidioides lutzii. PLoS Negl Trop Dis 13:e0007437.

Hoyos GL, McEwen JG, Brummer E, Castaneda E, Restrepo A and Stevens DA (1984) Chronic murine paracoccidioidomycosis: effect of ketoconazole on clearance of Paracoccidioides brasiliensis and immune response. Sabouraudia 22:419-426. 
Hrycyk MF, Garcia Garces H, Bosco SMG, de Oliveira SL, Marques SA and Bagagli E (2018) Ecology of Paracoccidioides brasiliensis, $P$. lutzii and related species: infection in armadillos, soil occurrence and mycological aspects. Med Mycol 56:950-962.

Kasuga T, White TJ and Taylor JW (2002) Estimation of nucleotide substitution rates in Eurotiomycete fungi. Mol Biol Evol 19:2318-2324.

Lacaz CS, Vidal MS, Heins-Vaccari EM, de Melo NT, Del Negro GM, Arriagada GL and Freitas RS (1999) Paracoccidioides brasiliensis. A mycologic and immunochemical study of two strains. Rev Inst Med Trop Sao Paulo 41:79-86.

Machado GC, Moris DV, Arantes TD, Silva LR, Theodoro RC, Mendes RP, Vicentini AP and Bagagli E (2013) Cryptic species of Paracoccidioides brasiliensis: impact on paracoccidioidomycosis immunodiagnosis. Mem Inst Oswaldo Cruz 108:637-643.

Martinez R (2017) New Trends trends in paracoccidioidomycosis epidemiology. J Fungi 3:e1

Matute DR, McEwen JG, Puccia R, Montes BA, San-Blas G, Bagagli E, Rauscher JT, Restrepo A, Morais F, Nino-Vega G et al. (2006) Cryptic speciation and recombination in the fungus Paracoccidioides brasiliensis as revealed by gene genealogies. Mol Biol Evol 23:65-73.

Muñoz JF, Farrer RA, Desjardins CA, Gallo JE, Sykes S, Sakthikumar S, Misas E, Whiston EA, Bagagli E, Soares CM et al. (2016) Genome diversity, recombination, and virulence across the major lineages of Paracoccidioides. mSphere 1:e00213-00216.

Nino-Vega GA, Calcagno AM, San-Blas G, San-Blas F, Gooday GW and Gow NA (2000) RFLP analysis reveals marked geographical isolation between strains of Paracoccidioides brasiliensis. Med Mycol 38:437-441.

Panunto-Castelo A, Freitas-da-Silva G, Bragheto IC, Martinez R and Roque-Barreira MC (2003) Paracoccidioides brasiliensis exoantigens: recognition by IgG from patients with different clinical forms of paracoccidioidomycosis. Microbes Infect 5:1205-1211.

Pigosso LL, Parente AF, Coelho AS, Silva LP, Borges CL, Bailao AM and Soares CM (2013) Comparative proteomics in the genus Paracoccidioides. Fungal Genet Biol 60:87-100.

Restrepo-Moreno A and Schneidau JD (1967) Nature of the skinreactive principle in culture filtrates prepared from Paracoccidioides brasiliensis. J Bacteriol 93:1741-1748.

Restrepo A and Jimenez BE (1980) Growth of Paracoccidioides brasiliensis yeast phase in a chemically defined culture medium. J Clin Microbiol 12:279-281.
Roberto TN, Rodrigues AM, Hahn RC and de Camargo ZP (2016) Identifying Paracoccidioides phylogenetic species by PCRRFLP of the alpha-tubulin gene. Med Mycol 54:240-247.

Salgado-Salazar C, Jones LR, Restrepo A and McEwen JG (2010) The human fungal pathogen Paracoccidioides brasiliensis (Onygenales: Ajellomycetaceae) is a complex of two species: phylogenetic evidence from five mitochondrial markers. Cladistics 26:613-624.

Sievers F, Wilm A, Dineen D, Gibson TJ, Karplus K, Li W, Lopez R, McWilliam H, Remmert M, Soding J et al. (2011) Fast, scalable generation of high-quality protein multiple sequence alignments using Clustal Omega. Mol Syst Biol 7:539.

Silva-Vergara ML, Martinez R, Chadu A, Madeira M, Freitas-Silva G and Leite Maffei CM (1998) Isolation of a Paracoccidioides brasiliensis strain from the soil of a coffee plantation in Ibia, State of Minas Gerais, Brazil. Med Mycol 36:37-42.

Teixeira MM, Theodoro RC, de Carvalho MJ, Fernandes L, Paes HC, Hahn RC, Mendoza L, Bagagli E, San-Blas G and Felipe MS (2009) Phylogenetic analysis reveals a high level of speciation in the Paracoccidioides genus. Mol Phylogenet Evol 52:273-283.

Teixeira MM, Theodoro RC, Nino-Vega G, Bagagli E and Felipe MS (2014) Paracoccidioides species complex: ecology, phylogeny, sexual reproduction, and virulence. PLoS Pathog 10:e1004397.

Theodoro RC, Bagagli E and Oliveira C (2008) Phylogenetic analysis of PRP8 intein in Paracoccidioides brasiliensis species complex. Fungal Genet Biol 45:1284-1291.

Turissini DA, Gomez OM, Teixeira MM, McEwen JG and Matute DR (2017) Species boundaries in the human pathogen Paracoccidioides. Fungal Genet Biol 106:9-25.

van Burik JA, Schreckhise RW, White TC, Bowden RA and Myerson D (1998) Comparison of six extraction techniques for isolation of DNA from filamentous fungi. Med Mycol 36:299303.

Vidal MS, Del Negro GM, Vicentini AP, Svidzinski TI, MendesGiannini MJ, Almeida AM, Martinez R, de Camargo ZP, Taborda CP and Benard G (2014) Serological diagnosis of paracoccidioidomycosis: high rate of inter-laboratorial variability among medical mycology reference centers. PLoS Negl Trop Dis 8:e3174.

Villar LA, Salazar ME and Restrepo A (1988) Morphological study of a variant of Paracoccidioides brasiliensis that exists in the yeast form at room temperature. J Med Vet Myco 26:269-276.

Wesselingh F and Salo J (2006) A Miocene perspective on the evolution of the Amazonian biota. Scr Geol 133:439-458.

Associate Editor: Célia Maria de Almeida Soares

License information: This is an open-access article distributed under the terms of the Creative Commons Attribution License (type CC-BY), which permits unrestricted use, distribution and reproduction in any medium, provided the original aticle is properly cited. 


\subsection{Publicação 2}

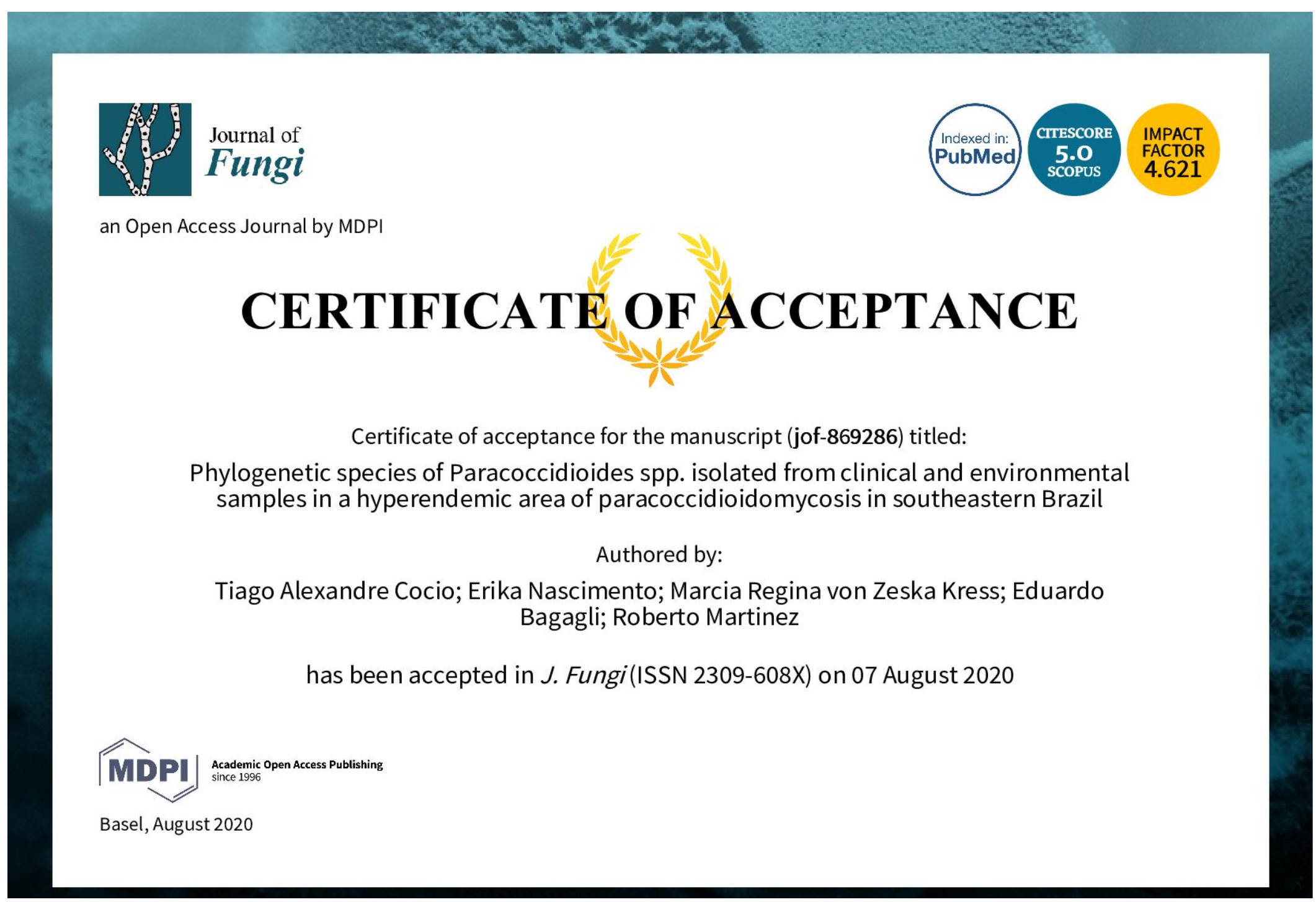


Article

\title{
Phylogenetic Species of Paracoccidioides spp. Isolated from Clinical and Environmental Samples in a Hyperendemic Area of Paracoccidioidomycosis in Southeastern Brazil
}

\author{
Tiago A. Cocio ${ }^{1, *([)}$, Erika Nascimento ${ }^{1}$, Marcia R. von Zeska Kress ${ }^{2}{ }^{\circledR}$, Eduardo Bagagli ${ }^{3}$ \\ and Roberto Martinez ${ }^{1}$ (B) \\ 1 Department of Internal Medicine, Ribeirão Preto Medical School, University of São Paulo, São Paulo, \\ Ribeirão Preto 14049-900, Brazil; erika.nascimento@gmail.com (E.N.); rmartine@fmrp.usp.br (R.M.) \\ 2 Department of Clinical Analyses, Toxicology and Food Science, School of Pharmaceutical Sciences of \\ Ribeirão Preto, University of São Paulo, São Paulo, Ribeirão Preto 14040-903, Brazil; kress@fcfrp.usp.br \\ 3 Department of Chemical and Biological Sciences, Institute of Biosciences-UNESP, São Paulo, \\ Botucatu 18618-691, Brazil; eduardo.bagagli@unesp.br \\ * Correspondence: alexcocio@gmail.com; Tel.: +55-16-3602-2468
}

Received: 1 July 2020; Accepted: 7 August 2020; Published: 11 August 2020

\begin{abstract}
Paracoccidioides brasiliensis complex and $P$. lutzii are the etiological agents of paracoccidioidomycosis. The geographic distribution of these species in South America is still poorly comprehended. Fifty samples of Paracoccidioides spp. were genotyped, with 46 clinical isolates predominantly isolated in the geographic area of Ribeirão Preto, SP, and four environmental isolates collected in Ibiá, MG, southeastern Brazil. These isolates were evaluated by PCR-RFLP (Restriction Fragment Length Polymorphism) of the $t u b 1$ gene and the sequencing of the gp 43 exon 2 loci. The species $P$. lutzii was confirmed by sequencing the internal transcribed spacer (ITS) region of the ribosomal DNA. P. brasiliensis sensu stricto S1b $(n=42)$ and S1a $(n=5), P$. americana $(n=1), P$. restrepiensis $(n=1)$, and P. lutzii $(n=1)$ were identified among the clinical isolates. All the environmental isolates were characterized as $P$. brasiliensis sensu stricto $\mathrm{S} 1 \mathrm{~b}$. The patient infection by P. lutzii, P. americana (PS2), and one isolate of $P$. brasiliensis sensu stricto S1b most likely occurred in a geographic area far from the fungal isolation site. No association was found between the infecting genotype and the disease form. These results expand the knowledge of the Paracoccidioides species distribution and emphasize that human migration must also be considered to pinpoint the genotypes in the endemic area.
\end{abstract}

Keywords: Paracoccidoides brasiliensis sensu stricto (S1a and S1b); Paracoccidioides americana (PS2); Paracoccidioides restrepiensis (PS3); Paracoccidoides lutzii; Paracoccidioidomycosis; eco-epidemiology

\section{Introduction}

Paracoccidioidomycosis (PCM) is a systemic fungal infection endemic to Latin America. Reports of PCM in South American countries show that about $80 \%$ of the cases are from Brazil, mainly in the southeast, south, and midwest regions, besides a low number of cases in the north and northeast regions [1].

PCM is caused by thermodimorphic fungi belonging to the genus Paracoccidioides, family Ajellomycetaceae, order Onygenales, class Eurotiomycetes, and is represented by five distinct species, including P. brasiliensis sensu stricto (variants S1a and S1b), which has been isolated in Brazil, Argentina, Paraguay, Peru, and Venezuela; P. americana (also known as PS2), distributed in Brazil and 
Venezuela; P. restrepiensis (also known as PS3), found mainly in Colombia; P. venezuelensis (also known as PS4), exclusively found in Venezuela; and P. lutzii, most commonly isolated in the midwest region of Brazil [2-5].

Determining the geographic distribution of the species of the genus Paracoccidioides spp. requires studies with epidemiological and clinical data, since important factors such as regional migration and the long latency period of PCM can make it difficult to know the exact location of the infection and the occurrence of each genotype in the endemic regions of PCM [6,7]. Genotypic studies have indicated that the predominant causative species of PCM in Brazil is P. brasiliensis sensu stricto (S1a and S1b). Its wide geographic occurrence includes particularly the southeast and south regions of Brazil (the states of Minas Gerais, São Paulo, Rio de Janeiro, Espírito Santo, Paraná, and Rio Grande do Sul) [8-10]. On a smaller scale, there are reports of the occurrences of P. americana (PS2) and P. restrepiensis (PS3) (southeast and south regions) in Brazil $[8,11,12]$. Brazil also has the largest endemic area of P. lutzii (midwest and north regions) [13,14].

Patients usually have the chronic PCM form, but it has not yet been determined whether certain genotypes may be related to clinical manifestations of this fungal disease [7].

This study aimed to evaluate genotypically the isolates of Paracoccidioides spp. from the Ribeirão Preto region, located in northeastern São Paulo state, southeast of Brazil, and relate the species to the clinical and epidemiological data of patients. The genotypic identification of Paracoccidioides spp. recovered from PCM cases in a hyperendemic area of the southeast of Brazil is unprecedented and may contribute to the eco-epidemiology of this mycosis.

\section{Materials and Methods}

\subsection{Samples of Paracoccidioides spp. and Cultivation Conditions}

Forty four samples of Paracoccidioides spp. isolated from patients treated at the Hospital das Clínicas of Ribeirão Preto Medical School, University of São Paulo-FMRP/USP (Ribeirão Preto, SP, Brazil)—from 1975 to 2019; two samples isolated from patients from Foz do Iguaçu, Paraná state (Table S1); and four environmental samples (one soil and three armadillos isolates) collected in Ibiá, Minas Gerais state, were used in this study (Table S2) $[15,16]$. The reference isolates were Pb18 (collected from the Laboratory of Medical Mycology Research of the Ribeirão Preto Medical School), representative of the species P. brasiliensis sensu stricto (S1b) [5]; Pbdog-EPM 194, representative of the species P. americana (PS2) [17]; T2-EPM 54, representative of the species P. restrepiensis (PS3) [18]; and $\mathrm{Pb} 01$, representative of the species P. lutzii [4] (Table S3). These isolates were maintained by successive subcultures on Sabouraud dextrose agar (Oxoid ${ }^{\circledR}$ LTD-Thermo Fisher Scientific ${ }^{\circledR}$, Basingstoke, Hampshire, UK), plus $0.15 \mathrm{~g} / \mathrm{L}$ of chloramphenicol sodium succinate (Blau Farmacêutica, Florianópolis, SC, Brazil), and incubated at $25^{\circ} \mathrm{C}$.

\subsection{Genomic DNA Extraction from Paracoccidioides spp.}

The genomic DNA of the isolates was obtained from mycelia grown in the modified synthetic liquid culture medium McVeigh and Morton [19] for 35 days at $25^{\circ} \mathrm{C}$ in an orbital stirrer (Infors HT-Ecotron ${ }^{\circledR}$, Bottmingen, Switzerland) at $130 \mathrm{rpm}$. The genomic DNA extraction was performed according to the method I (treated glass beads/phenol-chloroform/isoamyl alcohol) described by van Burik in 1998, with minimal modifications [20].

After obtaining the genomic DNA from the clinical and environmental isolates, treatment with RNase $A^{\circledR}$ (Thermo Fisher Scientific Inc. ${ }^{\circledR}$, Waltham, MA, USA) was carried out following the manufacturer's standards. The concentrations $(\mathrm{ng} / \mu \mathrm{L})$ of genomic DNA from the samples were determined using NanoDrop $2000^{\circledR}$ (Thermo Fisher Scientific Inc. ${ }^{\circledR}$, Waltham, MA, USA). 


\subsection{Methods and Primers Used in the Molecular Characterization of Paracoccidioides spp.}

The molecular characterization of clinical isolates was determined using the PCR-RFLP (Restriction Fragment Length Polymorphism) techniques of the $t u b 1$ gene [18] and the sequencing of the gp43 exon 2 loci gene, which encodes the $43 \mathrm{kDa}$ glycoprotein [10], to identify the species and varieties belonging to the genus Paracoccidioides. The isolate not identified by the PCR-RFLP technique of the $t u b 1$ gene was evaluated by sequencing the internal transcribed spacer (ITS) region of the ribosomal DNA to confirm the species of the genus Paracoccidioides [10,21]. The primers used in both methods, the annealing temperature, and their references are described in Table S4. The PCR reactions for each technique performed in this study were carried out using the vapo.protect ${ }^{\circledR}$ thermocycler (Eppendorf, Hamburg, Germany) and the Taq polymerase enzyme-GoTaq ${ }^{\circledR}$ Green Master Mix (Promega, Madison, WI, USA)-according to the manufacturer's instructions.

The molecular characterization using the PCR-RFLP technique generated PCR $t u b 1$ products approximately $263 \mathrm{bp}$ in size, being subjected to double digestion with the $B c l I$ and $M s p I$ endonucleases (Thermo Fisher Scientific Inc. ${ }^{\circledR}$, Waltham, MA, USA) at a concentration of $10 \mathrm{U} / \mu \mathrm{L}$, each for $16 \mathrm{~h}$ at $37^{\circ} \mathrm{C}$, according to the manufacturer's instructions. The fragments generated after double enzymatic digestion were submitted to electrophoresis on $3 \%$ agarose gel at $70 \mathrm{~V}$ for $180 \mathrm{~min}$ [18], and visualized in the presence of the SYBR ${ }^{\circledR}$ Safe DNA gel stain (Thermo Fisher Scientific Inc. ${ }^{\circledR}$, Waltham, MA, USA) with a 50 bp DNA ladder molecular weight marker (Sinapse ${ }^{\circledR}$ Inc., United States). The fragments generated after enzymatic digestion by endonucleases were visualized on the ChemoDoc ${ }^{\mathrm{TM}} \mathrm{XRS}+$ photo-documenter and photographed using the Image Lab ${ }^{\mathrm{TM}}$ software (Bio-Rad ${ }^{\circledR}$, Hercules, CA, USA).

\subsection{Sequencing of ITS1-5.8S-ITS2 rDNA Region, gp43 Exon 2 Loci, and Phylogenetic Analysis}

For the sequencing of the ITS1-5.8S-ITS2 rDNA region and the gp43 exon 2 loci $[10,21]$, the PCR products were purified using the Wizard ${ }^{\circledR}$ SV Gel kit and PCR Clean-UP System (Promega, Madison, WI, USA), according to the manufacturer's instructions. The nucleotide sequences were determined using the platform of the Human Genome and Stem-Cell Research Center of the Institute of Biosciences of the University of São Paulo (CEGH-CEL/IB-USP) with the ABI3730 DNA Analyzer ${ }^{\circledR}$ sequencer (Applied Biosystems, Foster City, CA, USA), using the BigDye ${ }^{\circledR}$ Terminator v3.1 Cycle Sequencing Kit (Thermo Fisher Scientific Inc. ${ }^{\circledR}$, Waltham, MA, USA), according to the manufacturer's instructions. The nucleotide sequences of the ITS1-5.8S-ITS2 rDNA region and the gp 43 exon 2 loci were analyzed using the ChromasPro ${ }^{\circledR}$ software (ChromasPro ${ }^{\circledR}$ 2.6.5, Technelysium Pty Ltd., Tewantin, QLD, Australia). The nucleotide sequences were compared with the database using the BLASTn-Basic Local Alignment Search Tool: https://blast.ncbi.nlm.nih.gov/Blast.cgi [22].

A phylogenetic analysis of clinical isolates was performed using the maximum likelihood (ML) method, in which the Tamura-Nei evolutionary model was applied to the ITS1-5.8S-ITS2 rDNA region sequences and the Kimura 2-parameter model to the gp43 exon 2 loci sequences, both with a 1000 replication bootstrap [10]. The multiple alignments using the Clustal W tool and the phylogenetic reconstruction were performed with the MEGA 6.0 software (Molecular Evolutionary Genetics Analysis) [23]. The Histoplasma capsulatum AMC_HC002 sequence was included in the phylogenetic analysis of the ITS1-5.8S-ITS2 rDNA region under the accession number KT275850.1 as an external group, and the B1-T1F1 nucleotide sequence was inserted to analyze the gp43 exon 2 loci as a reference for the S1a variety of P. brasiliensis sensu stricto under the GenBank accession number DQ003724.1 [10].

The nucleotide sequences of the studied isolates were deposited in the GenBank under the accession numbers of MK909758-MK909806 for gp43 exon 2 loci and MK886790 for ITS1-5.8S-ITS2 rDNA-HCRP 191 (Tables S1 and S2).

\subsection{Epidemiological Data of Patients with Isolation of Paracoccidioides spp.}

The medical records of patients were analyzed to obtain information regarding the PCM clinical form and the geographic origin of each studied individual. The epidemiological data, residence, 
and the clinical manifestation of the patient were related to the genotypic data of the clinical isolates of Paracoccidioides spp. obtained in this study.

\subsection{Ethics}

The study was approved by the Research Ethics Committee of the Hospital das Clínicas of Ribeirão Preto Medical School, University of São Paulo-FMRP/USP (Protocol HCRP 4456/2017), 17/04/2017.

\section{Results}

\subsection{Molecular Identification of Paracoccidioides spp. Isolates by the PCR-RFLP Technique of the tub1 Gene}

Forty seven (including environmental isolates-Table S2) among the 50 isolates analyzed in this study by the PCR-RFLP technique of the $t u b 1$ gene (46 clinical isolates and 4 environmental isolates-Table S1) were identified as belonging to the species P. brasiliensis sensu stricto (S1) because the $B c l I$ enzyme recognized the restriction site, generating two fragments (155 and $108 \mathrm{bp}$ ). The $t u b 1$ gene of isolate HCRP 199 had its cleavage site recognized by both enzymes ( $B c l$ I and MspI), generating three fragments $(62,93$, and $108 \mathrm{bp})$ and being classified as P. americana (PS2). The HCRP BAT isolate was identified as $P$. restrepiensis (PS3), because the endonucleases did not recognize the $t u b 1$ cleavage site, the gene remaining in its total integrity ( $263 \mathrm{bp}$ ) (Figure 1). The tub1 gene of the HCRP 191 isolate was not amplified by conventional PCR, and therefore the determination of the phylogenetic species of Paracoccidioides spp. by PCR-RFLP was inconclusive (Figure S1).
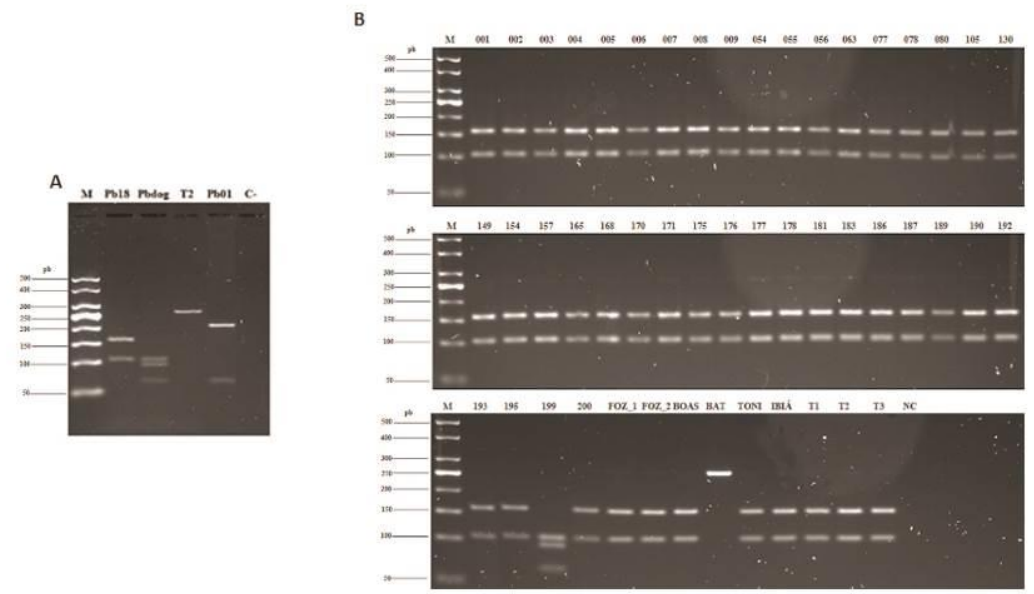

Figure 1. Patterns of fragments obtained after digestion with endonucleases BclI and MspI (PCR-RFLP of tub1 gene), showing a similarity between the clinical and environmental isolates of Paracoccidioides spp. and reference strains. (A) 3\% agarose gel with reference strains: Pb18-P. brasiliensis sensu stricto (S1b); Pbdog-EPM 194-P. americana (PS2); T2—EPM 54-P. restrepiensis (PS3); Pb_01—P. lutzii. (B) 3\% agarose gel with clinical (001 to FOZ_2, BAT, and TONI) and environmental (Ibiá, T1, T2, and T3) isolates evaluated in this study. Isolates 199 and BAT show a pattern corresponding, respectively, to Pbdog (P. americana (PS2)) and T2 (P. restrepiensis (PS3)), while the others have a pattern comparable to $\mathrm{Pb} 18$ (S1). The isolate HCRP 191 was not evaluated because there was no amplification of the tub1 gene. M: 50-bp DNA ladder molecular weight marker (Sinapse ${ }^{\circledR}$ Inc., USA). NC: negative control.

\subsection{Genotypic Identification and Phylogenetic Analysis Using the gp43 Exon 2 loci Gene Sequencing}

Among the 50 strains analyzed by the gp43 exon 2 loci sequencing, 47 isolates (including environmental samples) were identified as P. brasiliensis sensu stricto (S1); 5 isolates belonging to the S1a variety, with a $100 \%$ identity to DQ003724.1 B1-T1F1 (S1a); and 42 isolates (38 clinical and 4 environmental strains) belonging to the S1b variety, with a 100\% similarity to DQ003729.1 B17-Pb18 on GenBank. The isolate HCRP 199, characterized as P. americana (PS2), has a 100\% identity 
to the standard sequence P. americana (PS2) DQ003736.1 B13-Uberlândia. The isolate HCRP BAT, identified as $P$. restrepiensis (PS3), has a $100 \%$ identity to the standard sequence $P$. restrepiensis (PS3) KT251008.1-T2-EPM54. The isolate HCRP 191 was genotypically characterized as P. lutzii, showing a 100\% identity to EU870196.1 of Pb01 (P. lutzii), was deposited in GenBank (Spreadsheets S1).

The phylogenetic analysis of the gp 43 exon 2 loci sequences shows that 5 clinical isolates have an evolutionary proximity to DQ003724.1 B1-T1F1 P. brasiliensis sensu stricto (S1a), and 42 isolates are more similar to B17- $\mathrm{Pb} 18$ P. brasiliensis sensu stricto ( $\mathrm{S} 1 \mathrm{~b})$, including the environmental strains collected in Ibiá, MG, Brazil. The isolate HCRP199 is similar to EPM194-Pbdog P. americana (PS2), HCRP BAT has a genetic proximity to EPM54-T2 P. restrepiensis (PS3), and the isolate HCRP191 has a phylogenetic proximity to $\mathrm{Pb} 01-P$. lutzii (Figure 2).



Figure 2. Phylogenetic analysis of gp43 exon 2 of clinical and environmental isolates of Paracoccidioides spp. compared to the reference strains $(*)$, that were also sequenced for this study and had a $100 \%$ identity with the deposited sequences on GenBank under accession number: [Pb18-B17-DQ003729.1 (P. brasiliensis sensu stricto (S1b); EPM194-Pbdog-DQ003736.1 (P. americana (PS2); EPM54-T2-KT251008.1 (P. restrepiensis (PS3); Pb01-EU870196.1 (P. lutzii)]. Evolutionary history was measured by the maximum likelihood (ML) method based on the Kimura 2 model-parameter model. 


\subsection{The HCRP 191 Strain was Confirmed as P. lutzii by Sequencing the ITS1-5.8S-ITS2 rDNA Region}

The sequencing of the ITS1-5.8S-ITS2 rDNA region was performed to validate the identification of the species of the genus Paracoccidioides, as the isolate HCRP 191 was not molecularly identified by the PCR-RFLP technique of the $t u b 1$ gene. A $99.50 \%$ identity was observed with the ITS nucleotide sequence of $\mathrm{Pb} 01$ (P. lutzii) (EU870297.1), confirming the isolate as belonging to the species P. lutzii (Spreadsheet S1).

A phylogenetic analysis of the ITS1-5.8S-ITS2 rDNA region shows that the isolate HCRP191 has a similarity with $\mathrm{Pb} 01$ (P. lutzii) and a phylogenetic distance relative to $\mathrm{Pb} 18$ (S1b), EPM194-Pbdog (PS2), and EPM54-(PS3), which are species of the Paracoccidioides spp. complex and H. capsulatum AMC_HCO02 (Figure 3).

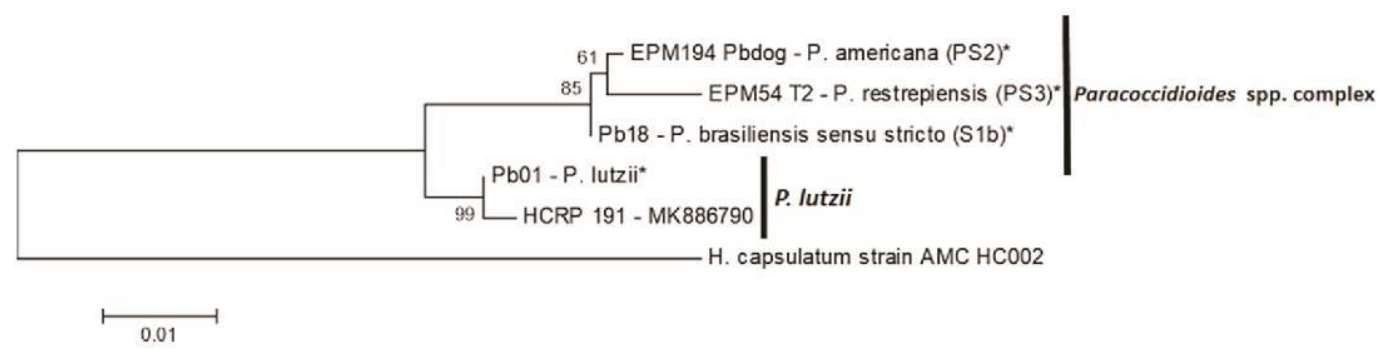

Figure 3. Phylogenetic analysis of the ITS1-5.8S-ITS2 rDNA region of the isolate HCRP191 compared to the reference strains $\left({ }^{*}\right)$, that were also sequenced for this study and had a $100 \%$ identity with the deposited sequences on GenBank under accession number: [Pb18-B17 (P. brasiliensis sensu stricto (S1b)), EPM194—Pbdog-(P. americana (PS2)) and EPM54-T2 (P. restrepiensis (PS3))—KT155977.1 for three reference strains; Pb01-EU870297.1 (P. lutzii)] and H. capsulatum AMC_HC002 are an external group. Evolutionary history was measured by the maximum likelihood (ML) method based on the Tamura-Nei model. The high similarity with Pb01 identifies HCRP 191 as P. lutzii.

\subsection{Geographic Origin of Patients and Clinical form of PCM}

Among the 46 isolates of clinical origin characterized genotypically in this study, $67.4 \%$ of the patients manifested the chronic form and $32.6 \%$ manifested the subacute form of PCM. Evaluating the clinical PCM manifestation by species of the Paracoccidioides spp. complex, 38 out of the 46 genotyped clinical isolates were characterized as P. brasiliensis sensu stricto variant $\mathrm{S} 1 \mathrm{~b}$, in whose patients $65.8 \%$ presented the chronic form and $34.2 \%$ presented the subacute form. Among the five clinical isolates identified as $P$. brasiliensis sensu stricto variant $\mathrm{S} 1 \mathrm{a}, 60 \%$ of the patients manifested the chronic form, and 40\% the subacute form. Patients from isolates HCRP 191 (P. lutzii) and HCRP 199 (P. americana-PS2) presented the chronic form. HCRP BAT (P. restrepiensis-PS3) was isolated from a patient with the subacute form of the disease (Table 1). 
Table 1. Paracoccidoidomycosis clinical form, patient residence and Brazilian region where the infection probably occurred (or collection area in the case of environmental isolates), according to Paracoccidioides species.

\begin{tabular}{|c|c|c|c|c|c|c|c|c|c|c|c|}
\hline \multirow[t]{2}{*}{ Paracoccidoides Species } & \multirow[t]{2}{*}{ Total Number } & \multicolumn{2}{|c|}{ Clinical Form $-n(\%)$} & \multicolumn{4}{|c|}{ Brazilian State of Residence- $n(\%)$} & \multicolumn{4}{|c|}{ Brazilian Region of Paracoccidioides spp. Infection $-n$ (\% } \\
\hline & & AC/Subacute & Chronic & SP & MG & PR & MA & SE & $\mathrm{s}$ & NE & $\mathrm{CW}$ \\
\hline P. brasiliensis sensu stricto $(\mathrm{S} 1 \mathrm{~b})$ & 38 & $13(34.2)$ & $25(65.8)$ & $31(81.6)$ & $4(10.5)$ & $2(5.3)$ & $1(2.6)$ & $35(92.1)$ & $2(5.3)$ & $1(2.6)$ & - \\
\hline P. brasiliensis sensu stricto (S1a) & 5 & $2(40)$ & $3(60)$ & $5(100)$ & - & - & - & $5(100)$ & - & - & - \\
\hline P. restrepiensis (PS3) & 1 & $1(100)$ & - & $1(100)$ & - & - & - & $1(100)$ & - & - & - \\
\hline P. lutzii & 1 & - & $1(100)$ & $1(100)$ & - & - & - & - & - & - & $1(100)$ \\
\hline P. brasiliensis sensu stricto $(\mathrm{S} 1 \mathrm{~b})^{*}$ & 4 & - & - & & $4(100)$ & & & $4(100)$ & - & - & - \\
\hline
\end{tabular}

SP—São Paulo State; MG—Minas Gerais State; PR—Paraná State; MA—Maranhão State; SE—Southeast; S—South; NE—Northeast; CW—Center West. $\left(^{*}\right)$ : Environmental isolates. 
The geographic origin showed that, among the 46 patients, 39 lived in the city and region of Ribeirão Preto, SP, Brazil. The patients from isolates HCRP 063 (P. brasiliensis sensu stricto S1b), HCRP 191 (P. lutzii), and HCRP 199 (P. americana-PS2) (Table S1) migrated to Ribeirão Preto, SP, Brazil, from the States of Maranhão, Mato Grosso, and Paraná, respectively. Six patients acquired PCM while residing in other endemic areas in the southeast and south of Brazil (Minas Gerais State—4; and Paraná State-2) (Figure 4 and Table 1).

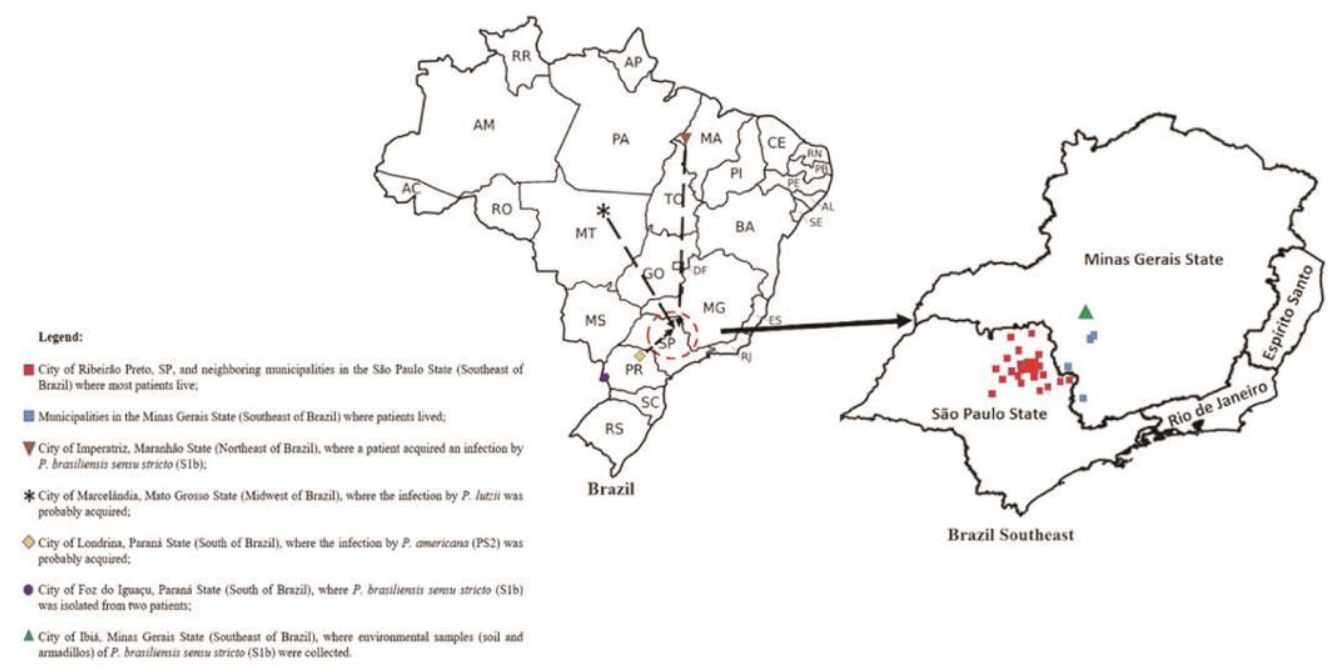

Figure 4. Map of Brazil highlighting the states of São Paulo and Minas Gerais and showing the geographic area centered by Ribeirão Preto, SP $\left(c^{-}-\right)$, where most patients lived; the migration of some patients who acquired the infection by Paracoccidioides spp. in other regions (-- - $\rightarrow$ ); and the collection site of the environmental isolates $(\boldsymbol{\Delta})$.

\section{Discussion}

The knowledge of the biogeography of the genus Paracoccidioides spp. is hampered by the migration of patients between the different PCM endemic regions, the long latency period of the chronic PCM form, and the difficulty in obtaining environmental isolates of this fungus [24]. This study evaluated genotypically Paracoccidioides spp. isolates from a single and defined endemic PCM area, partially covering the states of São Paulo and Minas Gerais in the southeast of Brazil [25]. Additionally, two isolates from patients in the region of Foz do Iguaçu, PR, in the south of Brazil, were also evaluated.

Among the clinical isolates genotypically characterized in this study, P. brasiliensis sensu stricto (S1a and S1b) showed a higher prevalence in the region of Ribeirão Preto, SP, Brazil, thus confirming reports in the literature on the high incidence of this phylogenetic species in South America and Brazil, particularly in the southeast and south $[7,9,10]$. The prevalent variety of $P$. brasiliensis sensu stricto among the clinical isolates evaluated in this study is S1b, which was identified in 38 (82.6\%) out of 46 patients. Except for one case that apparently acquired the fungal infection in the Maranhão State, the other patients lived in the states of São Paulo, Minas Gerais, and Paraná. The S1a variant was identified in 5 out of 46 patients with geographic origin in cities in the region of Ribeirão Preto, SP, Brazil (Table 1). The combined geographic distribution of $P$. brasiliensis sensu stricto S1a and S1b shows that 40 out of 43 individuals have remained in the states of the southeast since birth or have moved from the contiguous states of Minas Gerais and Paraná to the region of Ribeirão Preto, SP, Brazil, where they expressed PCM. No relationship was observed between the geographic area of residence of patients and the genotypic variants $\mathrm{S} 1 \mathrm{a}$ and or $\mathrm{S} 1 \mathrm{~b}$ of $P$. brasiliensis sensu stricto. The patient in one of the cases of PCM caused by P. brasiliensis sensu stricto S1b (isolate HCRP 170-Table S1) had AIDS and several relapses of opportunistic PCM until death. A phylogenetic and population study using complete genomes from 31 clinical isolates of Paracoccidioides spp. from some countries in South 
America identified P. brasiliensis sensu stricto S1a as the predominant variant in Argentina and the S1b variant distributed between Paraguay and Argentina [26]. This study also showed the occurrence of genotypes with some degree of admixing between S1a and S1b [26]. Therefore, the differentiation and/or classification between genotypes S1a and S1b based only on the two molecular markers used here (RFLP standard of the $t u b 1$ gene and gp 43 exon 2 polymorphism) can lead to different results from those obtained by the analysis of the complete genome, but without changing the classification in the $\mathrm{S} 1$ group. Therefore, the differentiation of the variants of P. brasiliensis sensu stricto (S1a and $\mathrm{S} 1 \mathrm{~b}$ ) carried out in this study has the limitation of the used methodology.

The phylogenetic species PS2 (P. americana) has been isolated with a lower prevalence of patients and environmental samples in endemic areas in the south and southeast of Brazil [10]. The isolate HCRP 199 (P. americana-PS2) was obtained from a 57-year-old male patient who presented the chronic form of PCM and lived in Ribeirão Preto, SP, although this individual had lived for a long time in Parana state (city of Londrina). P. americana (PS2) was also isolated from a dog with generalized lymphadenomegaly in Curitiba, PR [17]. Additionally, P. americana (PS2) was isolated from armadillos from rural regions of Botucatu, SP, showing that this species is endemic to the southeast of Brazil [10]. Recently, P. americana (PS2) was isolated in Rio de Janeiro state from patients with the chronic form of PCM [8]. Moreover, P. americana (PS2) was also isolated from patients with PCM in other Latin American countries, such as Venezuela, Uruguay, and Argentina [18].

P. restrepiensis (PS3) is another species that has been identified in endemic areas of Brazil but has its geographic distribution centered in Colombia. The isolate HCRP BAT, identified as the PS3 genotype, was obtained from a 33-year-old male patient who presented the subacute form of PCM. The patient, who was born and lived in the region of Ribeirão Preto, SP, had no history of travel to other geographic regions of the Brazilian territory and countries of Latin America, suggesting the acquisition of the fungus in that region of the southeast of Brazil [11]. The isolate HCRP BAT (also called Pb 327-B) had been evaluated together with P. brasiliensis samples from different South American countries using techniques such as RAPD and RFLP, being grouped close to P. brasiliensis (PS3) isolates from Colombia $[27,28]$. Recently, an isolate of a patient from Botucatu, in the São Paulo State, was identified as P. restrepiensis (PS3) [12], a genotype also isolated in Argentina and Peru [26].

P. lutzii has a predominant geographic distribution in the midwest region of Brazil, in the states of Mato Grosso, Mato Grosso do Sul, and Goiás, and its isolation is not usual in the southeast of Brazil $[9,29]$. The isolate HCRP 191 (P. lutzii) was obtained from a 55-year-old male patient who presented the chronic form of PCM. He was a resident of Ribeirão Preto, SP, Brazil, but was born in Parana state, in the south region, and had a long history of work and residence in rural areas of municipalities in the midwest region, where he probably acquired the fungal infection, which appeared as PCM years later in the southeast region of Brazil. However, P. lutzii can live saprophytically in the southeast and south of Brazil, as the isolate called IFM 54648 (or LDR 2), genotypically similar to Pb01 (P. lutzii), was obtained from a patient residing in Londrina, PR, but who had also resided in Botucatu, SP [30]. In addition, molecular traces of $P$. lutzii were found in soil and aerosol samples from armadillo burrows in the southeast of Brazil (São Paulo and Minas Gerais) [6,31], suggesting that this species is not found exclusively in the midwest of Brazil.

Most cases of PCM have a chronic disease form [7]. Besides the geographic origin and genotypic data, the clinical manifestation of PCM is an important characteristic to understand the pathogenicity of species of Paracoccidioides spp. complex and P. lutzii. Recent studies have evaluated the association of etiological agents (P. brasiliensis sensu stricto, P. americana, and P. lutzii) in the southeast and midwest regions of Brazil with the respective clinical form and found that most patients had the chronic disease form, regardless of the species of the genus Paracoccidioides [6,8,29]. In this study, the chronic form of PCM was observed in most cases attributed to $P$. brasiliensis sensu stricto and in patients infected with P. americana (PS2) and P. lutzii. The patient infected with P. restrepiensis (PS3) had the subacute form of PCM, but most of the clinical isolates PS3 correspond to cases of the chronic form [11,12]. It has not been possible to associate phylogenetic species with the clinical form of PCM, as the chronic form of 
PCM has been predominant in this and other studies in cases related to different Paracoccidioides spp. genotypes [7,29].

The environmental isolates evaluated here were collected approximately 20 years ago in Ibiá, Minas Gerais state, and have been kept since then in culture collection. The Ibiá isolate comes from the soil of a coffee plantation, and the other three isolates (Ibiá T1, Ibiá T2, and Ibiá T3) were obtained from armadillos (Dasypus novemcinctus) captured in the same municipality, whose territory is close to the area where some patients live with PCM [15,16]. Ibiá T1 (called EPM 101) was previously identified as P. brasiliensis sensu stricto by the PCR-RFLP method of the tub1 gene [18]. A phylogenetic study that includes soil and armadillo samples showed P. brasiliensis sensu stricto $\mathrm{S} 1 \mathrm{a}$ and $\mathrm{S} 1 \mathrm{~b}$ as the main agents of human PCM and in environmental samples from southeast Brazil [10].

The obtained data contribute to the knowledge of speciation related to Paracoccidioides spp. and show that human migration should be considered in the biogeography of the genus Paracoccidioides.

Supplementary Materials: The following are available online at http://www.mdpi.com/2309-608X/6/3/132/s1, Figure S1: Amplification of the tub1 gene to perform the PCR-RFLP technique in clinical and environmental isolates of Paracoccidioides spp.; Table S1: Clinical isolates used in this study; Table S2: Environmental isolates used in this study; Table S3: Reference strains used in this study; Table S4: Primer sequences used for molecular identification of Paracoccidioides spp.; Spreadsheets S1: Analysis of the sequence of clinical and environmental isolates in BLASTn, identification of identity of the sequences gp43 exon 2 loci and ITS1-5.8S-ITS2 rDNA region.

Author Contributions: Conceptualization, T.A.C., R.M.; Methodology, T.A.C.; Validation, T.A.C., E.N., M.R.v.Z.K., E.B., R.M.; Investigation, T.A.C., RM.; Formal Analysis, T.A.C., E.N., M.R.v.Z.K., E.B.; Data Curation, T.A.C., E.N., M.R.v.Z.K., E.B., R.M.; Writing-Original Draft Preparation, T.A.C., E.N., M.R.v.Z.K., E.B., R.M.; Writing—Review and Editing, T.A.C., R.M.; Supervision, R.M.; Funding Acquisition, R.M. All authors have read and agreed to the published version of the manuscript.

Funding: This research was supported by the Foundation for the Support of Teaching, Research and Service of the University Hospital (FAEPA), Ribeirão Preto Medical School, University of São Paulo.

Acknowledgments: T.A.C. thanks Zoilo Pires de Camargo, Department of Microbiology, Immunology, and Parasitology, Federal University of São Paulo-SP (Brazil) for kindly providing the Pb dog-EPM194 and T2-EPM54 strains used in this study; Eduardo Alexandre Loth from Western Paraná State University-Unioeste for kindly providing the isolates HCRP FOZ_1 and HCRP FOZ_2 for molecular identification in this study; the Coordination for the Improvement of Higher Education Personnel (CAPES Brazil-Finance Code 001) for granting the doctoral and postdoctoral scholarships (Grant numbers: 88882.180015/2018-01 (T.A.C.) and 88882.317609/2019-1 (E.N.)).

Conflicts of Interest: The authors declare no conflict of interest.

\section{References}

1. Martinez, R. New Trends in Paracoccidioidomycosis Epidemiology. J. Fungi 2017, 3, 1. [CrossRef]

2. Matute, D.R.; McEwen, J.G.; Puccia, R.; Montes, B.A.; San-Blas, G.; Bagagli, E.; Rauscher, J.T.; Restrepo, A.; Morais, F.; Nino-Vega, G.; et al. Cryptic speciation and recombination in the fungus Paracoccidioides brasiliensis as revealed by gene genealogies. Mol. Biol. Evol. 2006, 23, 65-73. [CrossRef]

3. Munoz, J.F.; Farrer, R.A.; Desjardins, C.A.; Gallo, J.E.; Sykes, S.; Sakthikumar, S.; Misas, E.; Whiston, E.A.; Bagagli, E.; Soares, C.M.; et al. Genome Diversity, Recombination, and Virulence across the Major Lineages of Paracoccidioides. MSphere 2016, 1. [CrossRef]

4. Teixeira, M.M.; Theodoro, R.C.; de Carvalho, M.J.; Fernandes, L.; Paes, H.C.; Hahn, R.C.; Mendoza, L.; Bagagli, E.; San-Blas, G.; Felipe, M.S. Phylogenetic analysis reveals a high level of speciation in the Paracoccidioides genus. Mol. Phylogenet. Evol. 2009, 52, 273-283. [CrossRef]

5. Turissini, D.A.; Gomez, O.M.; Teixeira, M.M.; McEwen, J.G.; Matute, D.R. Species boundaries in the human pathogen Paracoccidioides. Fungal Genet. Biol. 2017, 106, 9-25. [CrossRef]

6. Arantes, T.D.; Theodoro, R.C.; Teixeira Mde, M.; Bosco Sde, M.; Bagagli, E. Environmental Mapping of Paracoccidioides spp. in Brazil Reveals New Clues into Genetic Diversity, Biogeography and Wild Host Association. PLoS Negl. Trop. Dis. 2016, 10, e0004606. [CrossRef]

7. Shikanai-Yasuda, M.A.; Mendes, R.P.; Colombo, A.L.; Queiroz-Telles, F.; Kono, A.S.G.; Paniago, A.M.M.; Nathan, A.; Valle, A.; Bagagli, E.; Benard, G.; et al. Brazilian guidelines for the clinical management of paracoccidioidomycosis. Rev. Soc. Bras. Med. Trop. 2017, 50, 715-740. [CrossRef] [PubMed] 
8. De Macedo, P.M.; Teixeira, M.M.; Barker, B.M.; Zancope-Oliveira, R.M.; Almeida-Paes, R.; Francesconi do Valle, A.C. Clinical features and genetic background of the sympatric species Paracoccidioides brasiliensis and Paracoccidioides americana. PLoS Negl. Trop. Dis. 2019, 13, e0007309. [CrossRef] [PubMed]

9. Gegembauer, G.; Araujo, L.M.; Pereira, E.F.; Rodrigues, A.M.; Paniago, A.M.; Hahn, R.C.; de Camargo, Z.P. Serology of paracoccidioidomycosis due to Paracoccidioides lutzii. PLoS Negl. Trop. Dis. 2014, 8, e2986. [CrossRef] [PubMed]

10. Hrycyk, M.F.; Garcia Garces, H.; Bosco, S.M.G.; de Oliveira, S.L.; Marques, S.A.; Bagagli, E. Ecology of Paracoccidioides brasiliensis, P. lutzii and related species: Infection in armadillos, soil occurrence and mycological aspects. Med. Mycol. 2018, 56, 950-962. [CrossRef] [PubMed]

11. Cocio, T.A.; Nascimento, E.; Kress, M.R.V.Z.; Bagagli, E.; Martinez, R. Characterization of a Paracoccidioides spp. strain from southeastern Brazil genotyped as Paracoccidioides restrepiensis (PS3) and review of this phylogenetic species. Genet. Mol. Biol. 2020, 43, e20190201. [CrossRef]

12. Pereira, B.A.S. Pathogenicity and Immunogenicity of Clinical Isolates of the Paracoccidioides brasiliensis Complex; Repositório Institucional Unesp, Faculdade de Medicina de Botucatu, Master Universidade Estadual Paulista: Botucatu, Brazil, 2019. (In Portuguese)

13. Marques-da-Silva, S.H.; Rodrigues, A.M.; de Hoog, G.S.; Silveira-Gomes, F.; Camargo, Z.P. Occurrence of Paracoccidioides lutzii in the Amazon region: Description of two cases. Am. J. Trop. Med. Hyg. 2012, 87, 710-714. [CrossRef] [PubMed]

14. Teixeira Mde, M.; Theodoro, R.C.; Oliveira, F.F.; Machado, G.C.; Hahn, R.C.; Bagagli, E.; San-Blas, G.; Soares Felipe, M.S. Paracoccidioides lutzii sp. nov.: Biological and clinical implications. Med. Mycol. 2014, 52, 19-28. [CrossRef] [PubMed]

15. Silva-Vergara, M.L.; Martinez, R.; Camargo, Z.P.; Malta, M.H.; Maffei, C.M.; Chadu, J.B. Isolation of Paracoccidioides brasiliensis from armadillos (Dasypus novemcinctus) in an area where the fungus was recently isolated from soil. Med. Mycol. 2000, 38, 193-199. [CrossRef] [PubMed]

16. Silva-Vergara, M.L.; Martinez, R.; Chadu, A.; Madeira, M.; Freitas-Silva, G.; Leite Maffei, C.M. Isolation of a Paracoccidioides brasiliensis strain from the soil of a coffee plantation in Ibia, State of Minas Gerais, Brazil. Med. Mycol. 1998, 36, 37-42. [CrossRef] [PubMed]

17. De Farias, M.R.; Condas, L.A.; Ribeiro, M.G.; BoscoSde, M.; Muro, M.D.; Werner, J.; Theodoro, R.C.; Bagagli, E.; Marques, S.A.; Franco, M. Paracoccidioidomycosis in a dog: Case report of generalized lymphadenomegaly. Mycopathologia 2011, 172, 147-152. [CrossRef]

18. Roberto, T.N.; Rodrigues, A.M.; Hahn, R.C.; de Camargo, Z.P. Identifying Paracoccidioides phylogenetic species by PCR-RFLP of the alpha-tubulin gene. Med. Mycol. 2016, 54, 240-247. [CrossRef]

19. Restrepo, A.; Jimenez, B.E. Growth of Paracoccidioides brasiliensis yeast phase in a chemically defined culture medium. J. Clin. Microbiol. 1980, 12, 279-281. [CrossRef]

20. Van Burik, J.A.; Schreckhise, R.W.; White, T.C.; Bowden, R.A.; Myerson, D. Comparison of six extraction techniques for isolation of DNA from filamentous fungi. Med. Mycol. 1998, 36, 299-303. [CrossRef]

21. White, T.J. Amplification and direct sequencing of fungal ribosomal RNA genes for phylogenetics. In $P C R$ Protocols: A Guide to Methods and Applications; Academic Press: Cambridge, MA, USA, 1990; pp. 315-322.

22. Altschul, S.F.; Gish, W.; Miller, W.; Myers, E.W.; Lipman, D.J. Basic local alignment search tool. J. Mol. Biol. 1990, 215, 403-410. [CrossRef]

23. Tamura, K.; Stecher, G.; Peterson, D.; Filipski, A.; Kumar, S. MEGA6: Molecular Evolutionary Genetics Analysis version 6.0. Mol. Biol. Evol. 2013, 30, 2725-2729. [CrossRef] [PubMed]

24. Theodoro, R.C.; Teixeira Mde, M.; Felipe, M.S.; Paduan Kdos, S.; Ribolla, P.M.; San-Blas, G.; Bagagli, E. Genus paracoccidioides: Species recognition and biogeographic aspects. PLoS ONE 2012, 7, e37694. [CrossRef] [PubMed]

25. Bellissimo-Rodrigues, F.; Machado, A.A.; Martinez, R. Paracoccidioidomycosis epidemiological features of a 1,000-cases series from a hyperendemic area on the southeast of Brazil. Am. J. Trop. Med. Hyg. 2011, 85, 546-550. [CrossRef] [PubMed]

26. Teixeira, M.M.; Cattana, M.E.; Matute, D.R.; Munoz, J.F.; Arechavala, A.; Isbell, K.; Schipper, R.; Santiso, G.; Tracogna, F.; Sosa, M.L.A.; et al. Genomic diversity of the human pathogen Paracoccidioides across the South American continent. Fungal Genet. Biol. 2020, 140, 103395. [CrossRef] 
27. Calcagno, A.M.; Nino-Vega, G.; San-Blas, F.; San-Blas, G. Geographic discrimination of Paracoccidioides brasiliensis strains by randomly amplified polymorphic DNA analysis. J. Clin. Microbiol. 1998, 36, 1733-1736. [CrossRef]

28. Nino-Vega, G.A.; Calcagno, A.M.; San-Blas, G.; San-Blas, F.; Gooday, G.W.; Gow, N.A. RFLP analysis reveals marked geographical isolation between strains of Paracoccidioides brasiliensis. Med. Mycol. 2000, 38, 437-441. [CrossRef]

29. Hahn, R.C.; Rodrigues, A.M.; Della Terra, P.P.; Nery, A.F.; Hoffmann-Santos, H.D.; Gois, H.M.; Fontes, C.J.F.; de Camargo, Z.P. Clinical and epidemiological features of paracoccidioidomycosis due to Paracoccidioides lutzii. PLoS Negl. Trop. Dis. 2019, 13, e0007437. [CrossRef]

30. Takayama, A.; Itano, E.N.; Sano, A.; Ono, M.A.; Kamei, K. An atypical Paracoccidioides brasiliensis clinical isolate based on multiple gene analysis. Med. Mycol. 2010, 48, 64-72. [CrossRef]

31. Arantes, T.D.; Theodoro, R.C.; Da Graca Macoris, S.A.; Bagagli, E. Detection of Paracoccidioides spp. in environmental aerosol samples. Med. Mycol. 2013, 51, 83-92. [CrossRef]

(C) 2020 by the authors. Licensee MDPI, Basel, Switzerland. This article is an open access article distributed under the terms and conditions of the Creative Commons Attribution (CC BY) license (http://creativecommons.org/licenses/by/4.0/). 


\subsection{Publicação 3}

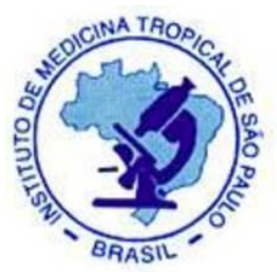

\section{REVISTA DO INSTITUTO DE MEDICINA TROPICAL DE SÃO PAULO}

Instituto de Medicina Tropical de São Paulo da Universidade de São Paulo

Av. Dr. Enéas de Carvalho Aguiar, 470

05403-000 - São Paulo - SP - Brasil

Fone: (11)3061-7005

E-mail: revimtsp@usp.br

http://www.imt.usp.br/sobre-o-imtsp/revista

http://www.scielo.br/rimtsp

revimtsp@usp.br

\section{CERTIFICADO DE PUBLICACÃO}

Certifico que o artigo "Paracoccidioidomycosis due to Paracoccidioides

lutzii complicated with adrenal injury and pulmonary arterial

hypertension", com Tiago Alexandre Cocio como co-autor, foi publicado

pela Revista do Instituto de Medicina Tropical de São Paulo em 13 de

novembro de 2020 e pode ser acessado online através do DOI

http://dx.doi.org/10.1590/s1678-9946202062089.

São Paulo, 23 de fevereiro de 2021

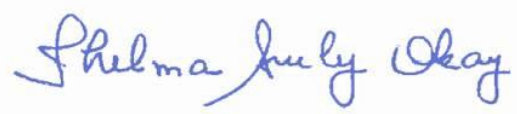

Profa. Dra. Thelma Suely Okay

Editora-Chefe 
R E V I S T A DO I N S T I T U T O $\mathrm{DE}$ M E D I C I N A T R O P I C A L $\mathrm{DE}$ S ÃO PAULO

JOURNAL OF THE SÃO PAULO INSTITUTE OF TROPICAL MEDICINE

'Universidade de São Paulo, Faculdade de Medicina de Ribeirão Preto, Departamento de Clínica Médica, Ribeirão Preto, São Paulo, Brazil

2Universidade de São Paulo, Faculdade de Medicina de Ribeirão Preto, Departamento de Patologia e Medicina Legal, Ribeirão Preto, São Paulo, Brazil

${ }^{3}$ Universidade de São Paulo, Faculdade de Ciências Farmacêuticas de Ribeirão Preto, Departamento de Análises Clínicas, Toxicológicas e Bromatológicas, Ribeirão Preto, São Paulo, Brazil

${ }^{4}$ Universidade Estadual Paulista 'Júlio de Mesquita Filho', Instituto de Biociências, Departamento de Ciências Químicas e Biológicas, Botucatu, São Paulo, Brazil

Correspondence to: Gilberto Gambero Gaspar

Universidade de São Paulo, Faculdade de Medicina de Ribeirão Preto, Departamento de Clínica Médica, Av. Bandeirantes, 3900, Monte Alegre, CEP 14049-900, Ribeirão Preto, SP, Brazil

Tel: +5516 3602-2468

E-mail: ggaspar@hcrp.usp.br

Received: 5 August 2020

Accepted: 22 October 2020

Rev Inst Med Trop São Paulo. 2020;62:e89
CASE REPORT

http://doi.org/10.1590/S1678-9946202062089

\section{Paracoccidioidomycosis due to Paracoccidioides lutzil complicated with adrenal injury and pulmonary arterial hypertension}

\author{
Gilberto Gambero Gaspar ${ }^{\circledR}$, Tiago Alexandre Cocio', Fernanda \\ Guioti-Puga', Erika Nascimento ${ }^{\circledR}$, Alexandre Todorovic Fabro ${ }^{2}$, Marcia \\ Regina von Zeska Kress ${ }^{3}$, Eduardo Bagagli ${ }^{4}$, Roberto Martinez ${ }^{1}$
}

\begin{abstract}
Paracoccidioidomycosis caused by Paracoccidioides lutzii is endemic in the Midwest of Brazil and its clinical spectrum is still little known due to the recent identification of this fungal species. A patient resident in Southeast Brazil, but who had lived for many years in the Midwest region, presented with skin injuries, chronic cough and bilateral adrenal involvement. Paracoccidioides spp. was isolated in culture from a skin lesion biopsy. This isolate was later identified as $P$. lutzii using gene sequencing. A favorable initial response to treatment with itraconazole was observed, but a few weeks later, the patient developed respiratory failure and worsening of lung lesions. Evaluation by computed tomography and echocardiography were suggestive of pulmonary arterial hypertension, and a bronchoscopic biopsy showed peribronchial remodeling. The patient completed the antifungal treatment but maintained the respiratory dysfunction. The reported case shows that $P$. lutzii can be isolated from patients in a geographic area far from the place of infection acquisition and that, as $P$. brasiliensis, it can cause adrenal injury and cardio-respiratory complications as a consequence of excessive necrosis and fibrosis.
\end{abstract}

KEYWORDS: Paracoccidioidomycosis. Paracoccidioides lutzii. Pulmonary arterial hypertension.

\section{INTRODUCTION}

Since the report of the first case in 1908, paracoccidioidomycosis infection and disease have been attributed to a single species of the dimorphic fungus Paracoccidioides brasiliensis. At the beginning of the $21^{\text {st }}$ century, some isolates of Paracoccidioides spp. had enough genetic polymorphism to be characterized as a new species, named $P$. lutzii ${ }^{1}$. This species has been isolated predominantly from patients in the Midwest region and around the Amazon region of Brazil ${ }^{2}$. The endemic area of $P$. lutzii is still little known and may have expanded, as there is molecular evidence of its presence in rural environments in other regions of Brazil ${ }^{3}$.

Regarding clinical manifestations, paracoccidioidomycosis by $P$. lutzii has been hidden for a long time within the disease caused by $P$. brasiliensis, either due to the lack of knowledge on new species or the similarity of the clinical manifestations related to Paracoccidioides species ${ }^{4}$. The number of reported cases of paracoccidioidomycosis caused by $P$. lutzii is still relatively small to fully establish the clinical spectrum of this disease. However, an atypical serological response, with absence or low antibody titer against $P$. brasiliensis antigens, has already 
been observed in cases of paracoccidioidomycosis in the Midwest region of Brazil ${ }^{5}$. Current evidence suggests that these patients were infected by $P$. lutzii, whose antigens are partially different from those of $P$. brasiliensis used in conventional serological tests ${ }^{6}$.

This report of paracoccidioidomycosis by $P$. lutzii shows that this fungal species can be isolated from patients living far from the known endemic aresa and shows clinical aspects that have not yet been reported in the disease caused by $P$. lutzii.

\section{CASE REPORT}

A 55-year-old man was admitted to the hospital presenting with widespread skin lesions, fever, chills, asthenia, and a loss of $16 \mathrm{~kg}$ in his body weight. The lesions looked like erythematous papules that progressively became painful ulcers. In the past few days, he had been experiencing diffuse pain throughout his body. He has also reported having dry cough for many years, but without dyspnea or other respiratory complaints.

The examination of the patient revealed numerous skin lesions, including erythematous papules and ulcerations on the head, face, trunk and limbs, which had a slightly elevated and erythematous border, with a depressed center covered with a crust. The lesions were generally circular and had a diameter between 0.5 and $1.5 \mathrm{~cm}$, but the frontal region of the face presented with an ulcer of approximately $3.0 \times 1.5 \mathrm{~cm}$ (Figure 1). He had a blood pressure of $100 \times 70 \mathrm{mmHg}$, heart rate of $82 / \mathrm{min}$ and respiratory rate of $20 / \mathrm{min}$. No lymphadenomegaly, hepatomegaly or splenomegaly were found, and pulmonary auscultation did not reveal any changes.

The patient was born in Realeza, Parana State, Brazil, and his family moved to Corpus Christi, Paraguay, when he was 9 years old, where he stayed for about 10 years. Then, he returned to Brazil, residing in Sete Quedas, Mato Grosso do Sul State, Marcelandia, Mato Grosso State, and
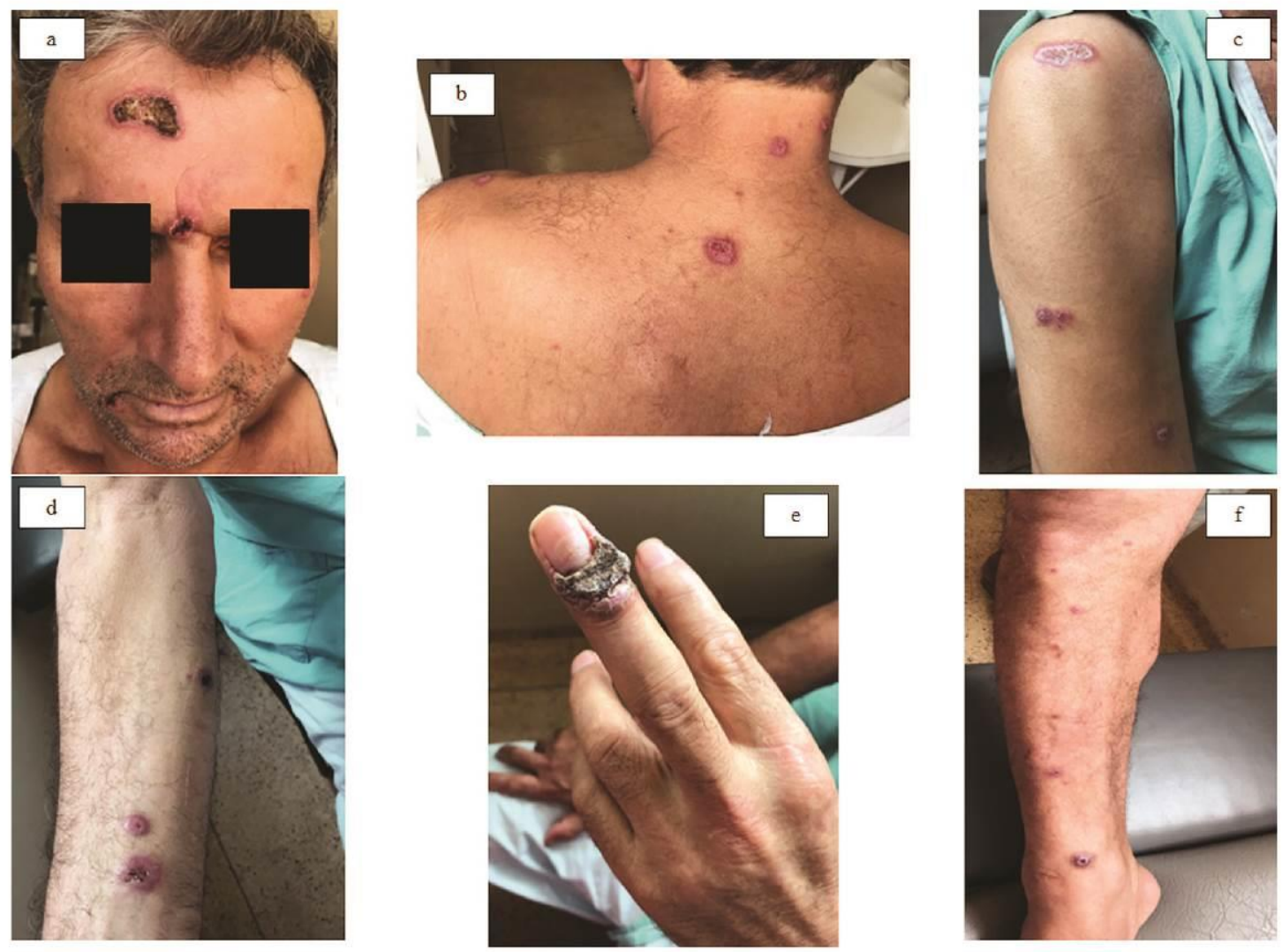

Figure 1 - Skin lesions caused by the spread of $P$. lutzii: a) Larger ulcer covered by crusts on the forehead and minor lesions on the root of the nose, zygomatic region and extremities of the labial commissure; b) Ulcers on the nape, back and left shoulder; c) Lesions at different stages on the shoulder and right arm; d) Forearm showing nodule and ulcers presenting with high and erythematous edges; e) Lesion with ulcerative crust on the distal phalanx of the middle finger of the left hand; f) Lower limbs showing severa different lesions ranging from papular to small nodules with central ulceration. 
Ribeirao Preto, Sao Paulo State, several years in each of these municipalities. He has worked for a long time as a truck and tractor driver, transporting manioc and wood, and has lived in a rural area, close to a deforestation area. $\mathrm{He}$ had contact with sawmills and prolonged exposure to wood dust. The patient claimed to be a heavy smoker since his youth and that he is used to drinking from $50 \mathrm{~mL}$ to $1 \mathrm{~L}$ of distilled alcoholic beverages per day. He has also reported a cutaneous leishmaniasis 16 years earlier.

Blood count and blood biochemical tests were normal, except for a high C-reactive protein $(12.3 \mathrm{mg} / \mathrm{dL})$. Serological tests for HIV infection, leishmaniasis, Chagas disease, and hepatitis $\mathrm{C}$ virus were negative, but serum anti-HBc Ag IgG antibodies were detected. Serological screening for systemic mycoses by the counterimmunoelectrophoresis (CIE) method was negative for histoplasmosis and aspergillosis, but positive for paracoccidioidomycosis with a 1:8 titer against P. brasiliensis antigen.

A chest X-ray showed diffuse infiltrates in both lungs, especially in the perihilar region, with a reticular and micronodular appearance and areas of alveolar opacities. The investigation through computed tomography (CT) showed that both adrenals were enlarged and had hypodense areas. Plasma cortisol $(7.8 \mu \mathrm{g} / \mathrm{dL})$ was just above the lowest level of the normal range $(5.0 \mu \mathrm{g} / \mathrm{dL})$. The histopathological examination of a skin lesion collected by biopsy showed granulomatous inflammatory infiltrateswith giant cells and yeasts presenting with exosporulation. The culture of the biopsied skin lesion led to the isolation of Paracoccidioides spp.

The patient was diagnosed with the chronic form of paracoccidioidomycosis, presenting with lung, skin and adrenal lesions. The antifungal treatment was carried out with itraconazole ( $400 \mathrm{mg} /$ day), leading to a progressive improvement, except for the appearance of dyspnea during intense physical activities. About 40 days after the beginning of the treatment, the patient had accentuated dyspnea, dry coughand worsening of his physical condition. The skin lesions were healed, but there were crepitations in both lungs, a respiratory rate of $36 / \mathrm{min}$, and arterial $\mathrm{O}_{2}$ saturation between $87 \%$ and $92 \%$. No clinical signs of heart failure were detected and echocardiography was not perfomed at this time. The radiological pattern of the lungs had worsened (Figure 2). Trimethoprim-sulfamethoxazole, at a dose of $160 \mathrm{mg}$ of trimethoprim was introduced intravenously every $8 \mathrm{~h}$ and prednisone was associated at a dose of $20 \mathrm{mg} /$ day, orally. The dyspnea decreased and treatment with itraconazole was reintroduced after 5 days in association with the corticosteroid therapy, maintained for 50 days.
After four months of antifungal therapy, pulmonary vital capacity and airway flow were normal in the spirometry evaluation. A chest CT scan showed thickened bronchi walls, some with dilation, lungs with a diffuse pattern that looked like micronodules, ground-glass opacities and cardiomegaly (Figure 2). Histological examination of tissues obtained by bronchoscopy revealed lymphoplasmacytic infiltrates associated with bronchial and vascular remodeling, aside from distortion of the tissue architecture (Figure 3). Doppler echocardiography showed slight dilation of the left atrium, ascending aorta and pulmonary artery, in addition to pulmonary arterial hypertension (pulmonary artery systolic pressure estimated at $42 \mathrm{mmHg}$, normal limit $<25 \mathrm{mmHg}$ ). The performed tests led to the conclusion that the patient had sequelae of paracoccidioidomycosis, functional changes in the lung and pulmonary circulation. The dose of itraconazole was reduced to $200 \mathrm{mg} /$ day, completing the 17 months of antifungal use.

In the clinical follow up, the patient maintained dyspnea of varied intensities. A new chest $\mathrm{CT}$ scan performed eight months after the end of treatment showed a decrease in pulmonary opacities, the presence of bronchiectasis, a slight increase in the right ventricle and dilation of the pulmonary artery trunk (32 mm, normal range: $<29 \mathrm{~mm}$ ).

Total genomic DNA of Paracoccidioides spp. isolated from the patient's lesions was extracted and ITS1-5.8S-ITS2 rDNA, as well as gp43 exon 2 gene regions were amplified by PCR, purified and sequenced. Gene sequencing was carried out on the platform of the Human Genome and Stem-Cell Research Center, Institute of Biosciences of the University of Sao Paulo. The comparison of the $\mathrm{Pb}$ 01 ( $P$. lutzii) nucleotide sequences revealed similarities of $99.5 \%$ with the ITS1-5.8S-ITS2 rDNA sequence (accession $\mathrm{N}^{\circ}$ EU870297.1) and 100\% with the gp43 exon 2 loci sequence (accession $N^{\circ}$ EU870196.1). The fungus isolated from the patient was therefore identified as $P$. lutzii and the obtained gene sequences (ITS1-5.8S-ITS2 rDNA and $g p 43$ exon 2) were deposited in GenBank (accession $\mathrm{N}^{\circ}$ MK909806 and MK886790, respectively) ${ }^{7}$.

\section{DISCUSSION}

The reported case is relevant due to $P$. lutzii successful isolation and unprecedented clinical characteristics regarding this fungal species. The patient lived in recent years in the region of Ribeirao Preto, SP, a municipality located in the Southeast of Brazil, and this fact initially suggested the acquisition of the infection in a place far from the endemic area of $P$. lutzii. This species was also isolated from a patient with the chronic PCM form who had a current and past residence in Londrina, Parana State, 



Figure 2 - Posteroanterior chest radiography (a) lateral position chest radiography (b) after 40 days of antifungal treatment: extensive bilateral interstitial and alveolar opacities, predominating in the middle thirds and bases of the lungs; $c$ ) chest computed tomography: ground-glass and reticular diffuse opacities through the lungs, micronodules, bronchiectasis and cardiomegaly; d) computed tomography of the abdomen: very enlarged adrenals with hypodense areas.

and Botucatu, Sao Paulo State, respectively, suggesting that P. lutzii infection was acquired in Southeast of Brazil ${ }^{8}$. In the case reported here, it is more likely that the patient acquired P. lutzii in the Midwest of Brazil, where he lived for many years and performed a professional activity with prolonged exposure to aspiration of Paracoccidioides spp. propagules. Paracoccidioidomycosis caused by $P$. brasiliensis can have a long incubation period, which is apparently valid for $P$. lutzii, allowing this species to be isolated much later outside its endemic region.

According to the classification adopted for $P$. brasiliensis, the patient had the chronic form of paracoccidioidomycosis. He had widespread skin lesion, lung lesion and, as an incidental finding, injury in both adrenals. In a series of cases of $P$. lutzii disease, all patients were classified with the chronic form of paracoccidioidomycosis ${ }^{9}$. The adrenals were supposed to be compromised by $P$. lutzii due to the extensive fungal dissemination in the patient and also by analogy with the disease caused by $P$. brasiliensis, whose chronic form is more associated with injury and even adrenal insufficiency ${ }^{10}$. The patient did not have Addison's disease, but a frequent subclinical reduction of adrenals function has been observed in paracoccidioidomycosis ${ }^{11}$.

Another interesting aspect of the reported case is the evolution of lung lesions and respiratory symptoms, culminating in pulmonary arterial hypertension. The patient had severe dyspnea, increased pulmonary radiological changes and relative hypoxia a few weeks after the beginning of the antifungal therapy, that improved with the use of corticosteroids. At that time, paracoccidioidomycosis had already been controlled by using itraconazole, considering the regression of skin lesions. Heart failure is a rare adverse affect of itraconazole ${ }^{12}$, but the patient's clinical 



Figure 3 - Histopathological examination of a transbronchial biopsy (HE staining): a) Vascular remodeling: dense adventitious and low cell layer; b) Vascular remodeling: exuberant thickening of the intima layer associated with endothelial hyperplasia; c) Bronchial remodeling: intense deposition of the extracellular matrix in the bronchial structures, low cell mucosa, with distortion of the architecture of the bronchial smooth muscle layer associated with thickening of the basement membrane, slight histiocytic anthracotic pigmentation (lower right quadrant) and secondary lymphatic dilation; d) Histiocytic black anthracotic pigmentation with a lymphatic distribution in the bronchovascular axis; e) Mild lymphoplasmacytic bronchitis associated with an architectural distortion of the bronchial remodeling and anthracotic pigmentation in histiocytes.

conditions excluded this hypothesis. An accentuation of the inflammatory process may take place at the initial stage of the paracoccidioidomycosis treatment, probably due to the pharmacological blocking of the infectious agent, necrosis and immunological recovery. The use of corticosteroids is recommended in patients with clinical complications due to excessive inflammation in Paracoccidioides spp. lesions ${ }^{2}$. The evolution towards the cure of the patient was accompanied by histological alterations evidenced in a bronchoscopic biopsy, culminating in fibrosis that caused structural alterations in the lungs, pulmonary arterial hypertension and functional pulmonary impairment. Pulmonary sequelae and respiratory dysfunction in paracoccidioidomycosis by $P$. brasiliensis are not uncommon ${ }^{13}$, as well as pulmonary arterial hypertension ${ }^{14}$. The outcome in the described case shows that it can also occur in the disease caused by $P$. lutzii. Cases progressing to severe lung injury and respiratory dysfunction in paracoccidioidomycosis by $P$. lutzii have already been reported $^{15,16}$.

The reported case shows new aspects of the disease caused by $P$. lutzii, expanding the clinical spectrum related to this species of Paracoccidioides. P. lutzii cases can occur far from the endemic area of this species, requiring a cautious analysis of data on the geographic distribution of Paracoccidioides species.

\section{ACKNOWLEDGMENTS}

Cocio TA and Nascimento $\mathrm{E}$ have a doctoral and a post-doctoral scholarship awarded by the Coordination for the Improvement of Higher Education Personnel (CAPES Brazil - Finance Code 001), grants No $88882.180015 / 2018-1$ and 88882.317609/2019-1, respectively. Fundação de Apoio ao Ensino, Pesquisa e Assistência of the Hospital das Clínicas da Faculdade de Medicina de Ribeirão Preto - USP (FAEPA) have also provided financial support.

\section{CONFLICT OF INTERESTS}

The authors declare no conflict of interests.

\section{CONSENT FOR PUBLICATION}

The patient signed an informed consent for the publication of the case.

\section{REFERENCES}

1. Teixeira MM, Theodoro RC, de Carvalho MJ, Fernandes L, Paes HC, Hahn RC, et al. Phylogenetic analysis reveals a high level of speciation in the Paracoccidioides genus. Mol Phylogenet Evol. 2009;52:273-83. 
2. Shikanai-Yasuda MA, Mendes RP, Colombo AL, Queiroz-Telles F, Kono AS, Paniago AM, et al. Brazilian guidelines for the clinical management of paracoccidioidomycosis. Rev Soc Bras Med Trop. 2017;50:715-40

3. Arantes TD, Theodoro RC, Teixeira MM, Bosco SM, Bagagli E. Environmental mapping of Paracoccidioides spp. in Brazil reveals new clues into genetic diversity, biogeography and wild host association. Plos Negl Trop Dis. 2016;10:e004606.

4. Arantes TD, Bagagli E, Niño-Veja G, San Blas G, Theodoro RC. Paracoccidioides brasiliensis and P. lutzii, a secret love afair. Rev Inst Med Trop Sao Paulo. 2015;57 Suppl 19:25-30.

5. Batista Jr J, Camargo ZP, Fernandes GF, Vicentini AP, Fontes CJ, Hahn RC. Is the geographical origin of a Paracoccidioides brasiliensis isolate important for antigen production for regional diagnosis of paracoccidioidomycosis? Mycoses. 2010;53:176-80.

6. Gegembauer G, Araujo LM, Pereira EF, Rodrigues AM, Paniago AM, Hahn RC, et al. Serology of paracoccidioidomycosis due to Paracoccidioidomycosis lutzii. Plos Negl Trop Dis. 2014;8:e2986.

7. Cocio TA, Nascimento E, von Zeska Kress MR, Bagagli E, Martinez R. Phylogenetic species of Paracoccidioides spp. isolated from clinical and environmental samples in a hyperendemic area of paracoccidioidomycosis in Southeastern Brazil. J Fungi (Basel). 2020;6:E132.

8. Takayama A, Itano EN, Sano A, Ono MA, Kamei K. An atypical Paracoccidioides brasiliensis clinical isolate based on multiple gene analysis. Med Mycol. 2010;48:64-72.
9. Hahn RC, Rodrigues AM, Della Terra PP, Nery AF, HoffmanSantos HD, Góis HM, et al. Clinical and epidemiologycal features of paracoccidioidomycosis due to Paracoccidioides lutzii. Plos Negl Trop Dis. 2019;13:e0007437.

10. Bellissimo-Rodrigues F, Bollela VR, Fonseca BA, Martinez R. Endemic paracoccidioidomycosis: relationship between clinical presentation and patients' demographic features. Med Mycol. 2013:51:313-8.

11. Tóbon AM, Agudelo CA, Restelpo CA, Villa CA, Quiceno W, Estrada S, et al. Adrenal function status in patients with paracoccidioidomycosis after prolonged post-therapy followup. Am J Trop Med Hyg. 2010;83:111-4.

12. Ahmad SR, Singer SJ, Leissa BG. Congestive heart failure associated with itraconazole. Lancet. 2001;357:1766-7.

13. Queiroz-Telles FV, Peçanha Pietrobom PM, Rosa Júnior M, Baptista RM, Peçanha PM. New insights on pulmonar paracoccidioidomycosis. Semin Respir Crit Care Med. 2020;41:53-68.

14. Tuder RM, el Ibrahim R, Godoy CE, De Brito T. Pathology of the human pulmonary paracoccidioidomycosis. Mycopathologia. 1985;92:179-88.

15. Marques-da-Silva SH, Rodrigues AM, de Hoog GS, SilveiraGomes F, Camargo ZP. Ocurrence of Paracoccidioides lutzii in the Amazon region: description of two cases. Am J Trop Med Hyg. 2012;87:710-4.

16. Hahn RC, Rodrigues AM, Fontes CJ, Nery AF, Tadano T, Queiroz LP, et al. Fatal fungemia due to Paracoccidioides lutzii. Am J Trop Med Hyg. 2014;91:394-8. 